\title{
BIOMASSA MICROBIANA DO SOLO SOB SISTEMA DE PLANTIO DIRETO NA REGIÃO DE CAMPOS GERAIS, TIBAGI, PR
}

\author{
SOLISMAR DE PAIVA VENZKE FILHO
}

\author{
Tese apresentada à Escola Superior de Agricultura \\ “Luiz de Queiroz", Universidade de São Paulo, para \\ obtenção do título de Doutor em Agronomia, Área \\ de Concentração: Microbiologia Agrícola.
}

P IR A C I C A B A

Estado de São Paulo - Brasil

Outubro - 2003 


\title{
BIOMASSA MICROBIANA DO SOLO SOB SISTEMA DE PLANTIO DIRETO NA REGIÃO DE CAMPOS GERAIS, TIBAGI, PR
}

\section{SOLISMAR DE PAIVA VENZKE FILHO}

Engenheiro Agrônomo

Orientador: Prof ${ }^{\mathrm{a}}$ Dra BRIGITTE JOSEFINE FEIGL

\author{
Tese apresentada à Escola Superior de Agricultura \\ “Luiz de Queiroz”, Universidade de São Paulo, para \\ obtenção do titulo de Doutor em Agronomia, Área \\ de Concentração: Microbiologia Agrícola.
}

P I R A C I C A B A

Estado de São Paulo - Brasil

Outubro - 2003 
Dados Internacionais de Catalogação na Publicação (CIP)

DIVISÃO DE BIBLIOTECA E DOCUMENTAÇÃO - ESALQ/USP

Venzke Filho, Solismar de Paiva

Biomassa microbiana do solo sob sistema de plantio direto na região de Campos Gera is, Tibagi, PR / Solismar de Paiva Venzke Filho. - -

Piracicaba, 2003.

$99 \mathrm{p}$.

Tese (doutorado) - Escola Superior de Agric ultura Luiz de Queiroz, 2003.

Bibliografia.

1. Biomassa microbiana do solo 2. Matéria orgânica do solo 3. Milho 4. Plantio direto 5. Sistema radicular6. Soja I. Título

CDD 631.46

"Permitida a cópia total ou parcial deste documento, desde que citada a fonte - O autor" 
A minha esposa

Vera Lúcia Scherholz Salgado de Castro

$\&$

A minha filha

Anna Verônica de Castro Venzke

OFEREÇO

Amigo

Engenheiro Agrícola José Ignácio Balego da Costa (in memorian)

DEDICO 


\section{AGRADECIMENTOS}

À Dra Brigitte Josefine Feigl, por ter aceitado o desafio de realizar juntos esse trabalho. Meu muito obrigado...Bri.

À Dra Marisa C. Piccolo, pesquisadora do Laboratório de Biogeoquímica Ambiental pela amizade e parceria no projeto FAPESP if 01/07168-7 que viabilizou o trabalho.

Ao chefe do Laboratório de Biogeoquímica Ambiental o Prof. Carlos Clemente Cerri pelo grande estímulo ao trabalho e amizade cultivada nesses anos de CENA.... Obrigado, Deus.

Ao Engenheiro Agrônomo Marcos Siqueira Neto, Ms. pelo companheirismo e o saudável convívio no campo e no laboratório. E assim, nasceu uma sólida e respeitosa amizade. Muito obrigado....Tucano!

Ao "chico" que nós acompanhou nessa jornada e nos fez sentir a angústia, mas também o alivio, deu o sorriso e também a lágrima, nos fez gritar e também silenciar, mostrou caminho para glória, mas também para o fracasso.....nesse dualismo construiu a experiência cientifica que hoje temos e nem a morte nos tira.

Ao Sr. Lúcio Miranda e o Eng. Agrônomo Paulo Sérgio, por mais uma vez deixar aberto às porteiras da Fazenda Santa Branca para realização desse trabalho. E, aqui um especial agradecimento ao Eng. Agrônomo Jorge do Rocio Ferreira e aos funcionários da Empresa Lúcio Miranda em nome do Sr. Milton Banisk e do Zeca Diabo, prontidão e ao apoio na condução da árdua tarefa de amostragem de solo, Valeu!! 
Aos amigos do Laboratório de Biogeoquímica do solo (CENA/USP), Sandra Nicolete, Mara Piacentini, Lílian de Campos, Dagmar Marchesoni, Luiz Hiroshi, Maria Cristina S. Rosa pela amizade e o sorriso de cada manhã.... Agradeço de coração!

Ao Prof. Dr. Lorival Fontes Junior - Unimep, pela amizade e grandiosa ajuda na avaliação do sistema radicular.

Aos estagiários Éverton Hiraoka (ESALQ); Viviane Gonzáles (Unimep); Daniela Tuturati (Unimep), Maria Flávia V. Gonçalves (Unimep), Andréa P. Perin (Unimep). Sem vocês ..... ficaria impossível. Obrigada Gente!!!

Aos colegas de Pós-Graduação do Lab. Biogeoquímica Ambiental agradeço pela amizade e convívio. Atenção à chamada! são eles: Dinailson Campos, Maria da Conceição Carvalho, Silvana Fernandes, Edgar de Luca, Marilda Mariotti, Marcos Siqueira, Mariana Pavei, Gabor Szakács, Karine Augusti, Christiane Teixeira, Caio Passionoto, Marcelo Cassiolato, Janaína do Carmo, Norberto Noronha, Karina Cenciani, Marcelo Galdos.

Aos pesquisadores da IRD/ORSTOM, Vincent Echenbrenner, Christian Feller, Matial Bernoux e Vincent Chaplot pela amizade e companhia.

Ao Centro de Energia Nucler na Agricultura (CENA/USP) pelo apoio logístico.

Ao CNPq pela concessão da bolsa de estudo.

Ao Decano Prof. Dr. Luiz Gonzaga do Prado Filho pela amizade e orientação recebida.

Ao Prof. José Leonardo - Esalq/USP e pesquisadora Dra. Sueli S. Freitas (IAC Campinas) pelas sugestões no presente trabalho decorrente da qualificação deste pósgraduando.

A todos aqueles que, de uma maneira ou outra, prestaram o seu apoio e incentivo para a realização desse trabalho. Meu muito obrigado! 


\section{SUMÁRIO}

LISTA DE FIGURAS ........... $\begin{gathered}\text { Página } \\ \text { ix }\end{gathered}$

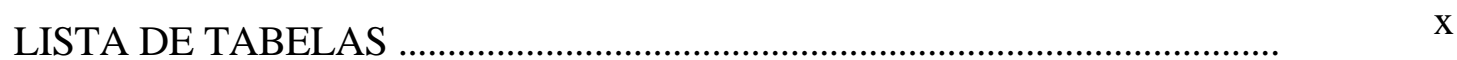

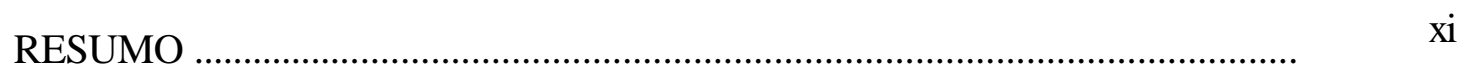

SUMMARY ………...........................................................................

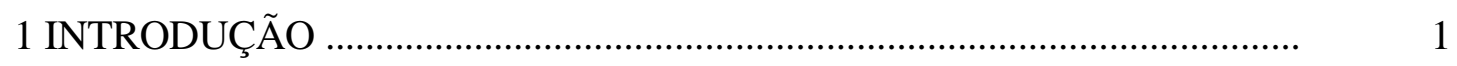

2 REVISÃO DE LITERATURA .................................................................. 5

2.1 Sistema plantio direto e a biomassa microbiana do solo .............................. $\quad 5$

2.2 Efeito das raízes sobre a biomassa microbiana do solo ................................... $\quad 11$

3 BIOMASSA MICROBIANA EM FUNÇÃO DO TEMPO DE ADOÇÃO DO SISTEMA DE PLANTIO DIRETO E DA TEXTURA DO SOLO .................... 14

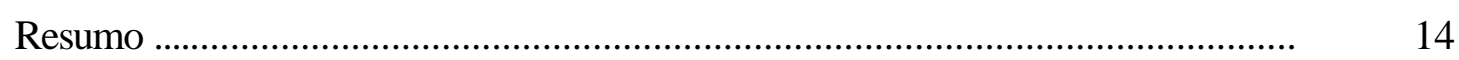

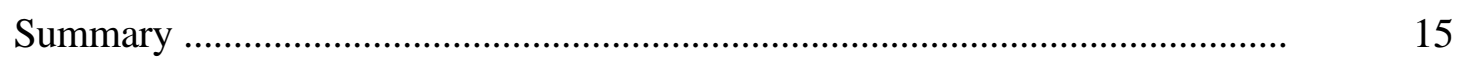

3.1 Introdução ............................................................................................ 16

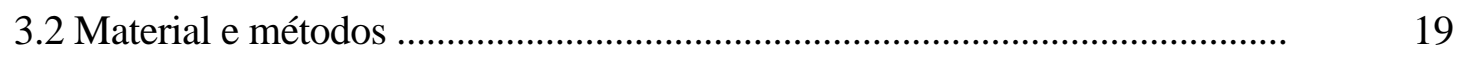

3.2.1 Seleção e localização das áreas de estudo ................................................... 19

3.2.2 Caracterização edafo-climática da região .................................................... 19

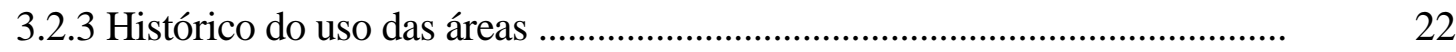

3.2.4 Caracterização física e química do solo das áreas .......................................... 
3.2.5 Instalação, condução e época amostragem do experimento ..........................

3.2.6 Procedimento de coletas e armazenamento de amostra de solo ..................... 31

3.2.7 Determinação da concentração de amônio e nitrato .........................................

3.2.8 Determinação do teor de $\mathrm{C}$ e $\mathrm{N}$ total do solo ....................................................

3.2.9 Determinação do C e N microbiano ..............................................................

3.2.10 Forma de análise dos resultados ..............................................................

3.3 Resultados e discussão ..........................................................................

3.3.1 Características física e química das áreas estudadas .................................... 35

3.3.2 Variação do C e N microbianos em função do tempo de adoção do SPD .... $\quad 38$

3.3.3 C e N microbiano em solos de diferentes texturas ..........................................

3.3.4 Correlação entre o C e N microbiano e o $\mathrm{N}$ mineral do solo .........................

3.4 Conclusões ......................................................................................... 53

4 PARAMÊTROS RADICULARES DO MILHO E DA SOJA SOB PLANTIO 54

DIRETO E SUA INFLUÊNCIA NA BIOMASSA MICROBIANA

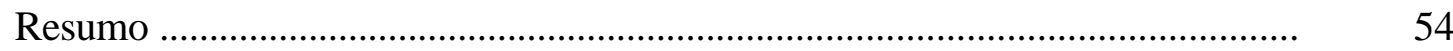

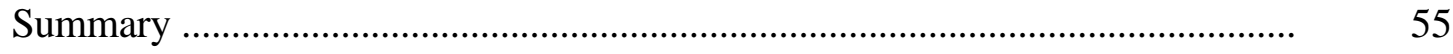

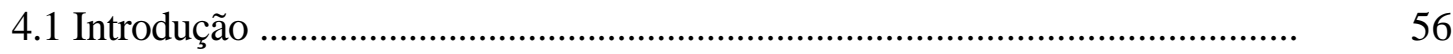

4.2 Material e métodos ................................................................................... 58

4.2.1 Localização da área de amostragem e trato cultural .......................................

4.2.2 Avaliação do sistema radicular do milho e da soja ........................................

4.2.3 Determinação dos teores de $\mathrm{C}$ e $\mathrm{N}$ das raízes, do solo e microbiano ........... 61

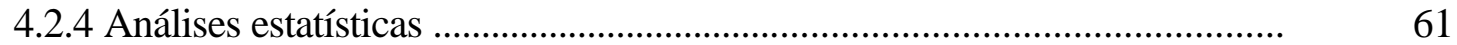




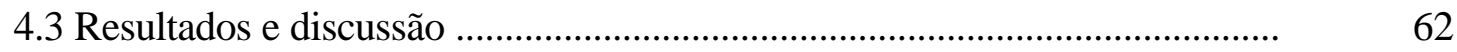

4.3.1 Distribuição do sistema radicular do milho e da soja no perfil do solo ......... 62

4.3.2 Biomassa microbiana no perfil do solo ........................................................... 68

4.3.3 Relação entre o C e N microbiano e os parâmetros radiculares do milho e

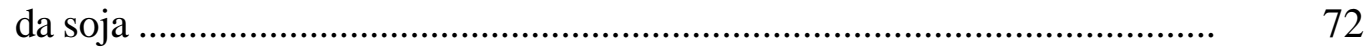

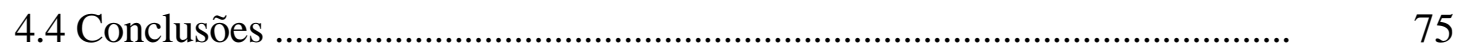

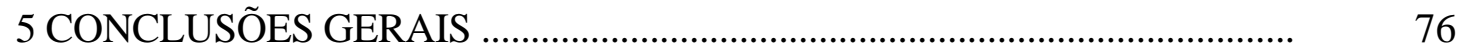

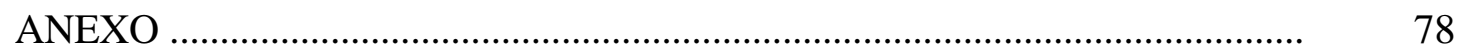

REFERÊNCIAS BIBLIOGRAFICAS …..................................................... 82 


\section{LISTA DE FIGURAS}

1 Localização das áreas de estudos na Fazenda Santa Branca, município de Tibagi (PR).

2 Temperatura média e precipitação acumulada mensal de setembro de 2000 a fevereiro de 2002.

3 Representação gráfica do histórico da ocupação agrícola das terras pertencente à Fazenda Santa Branca, com destaque para as áreas em estudos. .

4 Esquema dos pontos de coleta de solo das áreas em estudos.

5 Amostragem de solo.

6 Teores de $\mathrm{C}$ e $\mathrm{N}$ em solos de diferentes classes texturais e sob 12 e 22 anos de adoção de sistema plantio direto na camada $0-20 \mathrm{~cm}$.

7 Representação da amostragem do sistema radicular na cultura do milho.

8 Representação gráfica da distribuição do sistema radicular do milho e da soja no perfil do solo.

9 Contribuição das raízes grossas e finas no sistema radicular do milho e da soja.

10 Parâmetros radiculares do milho e da soja em solo sob sistema plantio direto.

$11 \mathrm{C}$ e $\mathrm{N}$ microbiano e sua relação com o $\mathrm{C}$ e $\mathrm{N}$ total sob influência do sistema radicular do milho e da soja em solo sob sistema plantio direto. 


\section{LISTA DE TABELAS}

1 Código das áreas selecionadas em função do tempo de adoção do sistema de plantio direto e da classe textural.

2 Caracterização granulométrica das áreas

3 Densidade do solo

4 Caracterização química das áreas em estudo.

5 Época de amostragem do solo, resíduos e cultura no momento da coleta, tratos culturais aplicados no período entre coletas e o último trato cultural realizado antes da coleta nas áreas estudadas.

6 Teores de carbono e nitrogênio total nas áreas de estudo.

7 C e N-microbiano em função do tempo de adoção do sistema plantio direto em solo de textura argilosa sob duas sequiências de culturas.

8 Efeito da textura do solo no $\mathrm{C}$ e $\mathrm{N}$-microbianos nas diferentes épocas em áreas há 12 anos sob sistema plantio direto em duas seqüências de culturas ..

9 Coeficiente de correlação linear entre o C e N-microbianos, $\mathrm{N}-\mathrm{NH}_{4}{ }^{+}, \mathrm{N}-$ $\mathrm{NO}_{3}{ }^{-}$e o N-mineral do solo nas diferentes áreas e seqüências de culturas. ....

10 Quantidades de C e $\mathrm{N}$ nas diferentes classes de raízes do milho e da soja em solo sob sistema plantio direto. 


\title{
BIOMASSA MICROBIANA DO SOLO EM SISTEMA DE PLANTIO DIRETO NA REGIÃO DE CAMPOS GERAIS, TIBAGI, PR
}

\author{
Autor: SOLISMAR DE PAIVA VENZKE FILHO \\ Orientadora: Profa. Dra. BRIGITTE JOSEFINE FEIGL
}

\section{RESUMO}

A demanda por informações relativas à ciclagem de nutrientes no solo sob sistema plantio direto (SPD) motivou o estudo das variações da biomassa microbiana do solo (BMS) em áreas com diferentes texturas submetidas há longo tempo a esse tipo de manejo. Na região de Campos Gerais, Tibagi (PR) é adotada a sequiência de culturas soja e milho no verão, seguidos de trigo e aveia preta no inverno há mais de 20 anos. O objetivo foi monitorar as variações do $\mathrm{C}$ e $\mathrm{N}$-microbianos durante um ciclo de rotação em quatro áreas, sendo três com histórico de 12 anos sob SPD, com textura muito argilosa (PD12-TmuA), argilosa (PD12-TA), e média argilosa (PD12-TmeA), e uma com histórico de 22 anos sob SPD com textura argilosa (PD22-TA). No período de 18 meses foram realizadas nove amostragens de solo em quatro camadas $(0-2,5 ; 2,5-5 ; 5$ 10; 10-20 cm). Foram avaliadas também alguns parâmetros das raízes do milho e da soja 
no PD22-TA visando determinar a influência de culturas distintas (plantas C4 e C3) sobre a concentração de BM no perfil do solo. A diferença de dez anos no tempo de adoção do SPD determinou aumento do Cmicrobiano no PD22-TA sobre o PD12-TA nas camadas mais profundas do solo. O PD22-TA também apresentou em média 30,8 kg $\mathrm{N}_{\text {mic }} \cdot$ ha $^{-1}$ mais BM-N que o PD12-TA na camada 0-20cm, com menor amplitude de variação. As diferenças na textura dos solos há 12 anos sob SPD resultou em maiores médias de $\mathrm{C}$ e Nmicrobiano na camada 0-20 cm na área mais argilosa (PD12-TmuA), exceto nos 20 dias após o plantio do trigo (jun/01). O PD12-TA e o PD12-TmeA não apresentaram diferenças significativas nas quantidades de C-microbiano somente na camada de $05 \mathrm{~cm}$. O C-microbiano apresentou correlação com o $\mathrm{N}^{-} \mathrm{NH}_{4}^{+}$e o $\mathrm{N}_{-} \mathrm{NO}_{3}^{-}$ que o Nmicrobiano, independente da textura, do tempo de adoção SPD e da sequiência de culturas. O sistema radicular fasciculado do milho totalizou $1324 \mathrm{~kg} \mathrm{C}^{-1}$ e $58 \mathrm{~kg} \mathrm{~N}$ $\mathrm{ha}^{-1}$, com maior densidade por comprimento e por matéria seca de raízes ativas e raízes em vias de decomposição na camada superficial. O sistema radicular pivotante da soja (392 $\mathrm{kg} \mathrm{C} \mathrm{ha}^{-1}$ e $21 \mathrm{~kg} \mathrm{~N} \mathrm{ha}^{-1}$ ) teve contribuição maior de raízes finas e densidade por comprimento do que o milho. O efeito das raízes do milho sobre o C-microbiano atingiu camadas mais profundas do que as raízes da soja. O Nmicrobiano foi estimulado pela concentração das raízes finas ativas e pelas raízes em decomposição ou de forma indefinida, possivelmente devido à maior concentração de $\mathrm{C}$ e $\mathrm{N}$ de fácil assimilação liberado ao solo. Concluiu-se que em função do tempo de adoção do SPD o Cmicrobiano aumenta em profundidade e o N-microbiano apresenta menor variação na camada 0-20 cm. A quantidade de $\mathrm{C}$ e N-microbiano é influenciada pela textura do solo. Entretanto, solos de classes textural próximas e sob SPD podem apresentar quantidades iguais de C-microbiano na camada 0-5 cm durante o sistema de produção. 


\title{
SOIL MICROBIAL BIOMASSA UNDER NO-TILLAGE IN THE REGION OF CAMPOS GERAIS, TIBAGI, PR
}

\author{
Author: SOLISMAR DE PAIVA VENZKE FILHO \\ Adviser: Prof- Dra BRIGITTE JOSEFINE FEIGL
}

\section{SUMMARY}

The demand for information about the nutrient cycling in soils under no-tillage motivated the study about soil microbial biomass (SMB) variations in different texture soils submitted for a long period to this kind of management system. The usual sequence of crops adopted for more than 20 years in Campos Gerais, Tibagi (PR) is soybean/corn during the summer and wheat/oats during the winter. The objective was to keep track of the microbial-C and $\mathrm{N}$ variations during a crop rotation cycle in four areas: three of them have been cultivated for 12 years under the no-tillage system, with a clay (PD12-TmuA), a sandy clay (PD12-TA), and a sandy clay loam (PD12-TmeA) texture, and a fourth, 22 years under the no-tillage system with a sandy clay loam textural class (PD22-TA). Nine soil samplings were performed during a period of 18 months, each time collecting four soil layers $(0-2,5 ; 2,5-5 ; 5-10 ; 10-20 \mathrm{~cm})$. Several corn and soybean root parameters 
were also evaluated in PD22-TA to determine the influence of diverse crops (C4 and C3 plants) on the microbial biomass concentration in the soil profile. The ten-year difference in no-tillage system adoption caused and increase of microbiatC in PD22-TA in relation to PD12-TA in the deeper soil layers. The PD22-TA also showed, on average, $30,8 \mathrm{~kg} \mathrm{~N} \mathrm{~N}_{\text {mich }} \mathrm{ha}^{-1}$ more microbial-N than the PD12-TA in the 0-20 cm, with a narrower range of variation. The divergence in texture among the 12-year no-till sites resulted in higher microbial- $\mathrm{C}$ and $\mathrm{N}$ means in the $020 \mathrm{~cm}$ soil layer, except for 20 days after the wheat sowing. PD12-TA and PD12-TmeA did not show significant differences in the microbial-C amounts only for the $0-5 \mathrm{~cm}$ layer. Microbial-C was more positively correlated with $\mathrm{N}_{-} \mathrm{NH}_{4}{ }^{+}$and $\mathrm{N}_{-} \mathrm{NO}_{3}{ }^{-}$than microbial-N, independently of soil texture, time since no-till adoption and crop sequence. The corn root system totaled $1324 \mathrm{~kg} \mathrm{C}$ $\mathrm{ha}^{-1}$ and $58 \mathrm{~kg} \mathrm{~N} \mathrm{ha}^{-1}$ in the upper soil layer, with higher density per length and per active root dry mass, and more roots in decomposition. The soybean root system $(392 \mathrm{~kg}$ $\mathrm{C} \mathrm{ha}^{-1}$ and $21 \mathrm{~kg} \mathrm{~N} \mathrm{ha}^{-1}$ ) contributed more with fine roots and density per length than the corn. The effect of the corn root system on microbial-C reached deeper soil layers than the soybean roots. Microbial-N was stimulated by fine and active root concentration and by roots in decomposition phase, probably due to higher labile $\mathrm{C}$ and $\mathrm{N}$ concentration released to the soil. It was concluded that the microbial-C increased in depth along the period of no-till adoption, while the microbial-N showed less variation in the $0-20 \mathrm{~cm}$ soil layer. Both microbial-C and $\mathrm{N}$ are influenced by soil texture, although similar textural classes under no-till can maintain similar microbial-C amounts in the $0-5 \mathrm{~cm}$ soil layer during the crop production system. 


\section{INTRODUÇÃO}

Os sistemas conservacionistas de exploração agrícola, entre os quais o sistema plantio direto (SPD), têm como princípio manter e/ou aumentar o teor de matéria orgânica no solo (MOS). Os resultados de muitos trabalhos têm mostrado aumento de MOS em áreas com adoção do SPD em comparação com outros tipos de manejo do solo. Atribui-se esse aumento à proteção física e química da MOS, dada principalmente pela manutenção dos resíduos na superfície, alterações da estrutura do solo e pela rotação de culturas (Havlin et al., 1990; Carter, 1992, Cambardella \& Elliot, 1992; Bayer \& Bertol, 1999; Sá, J. 2001), resultando no aumento da fauna (Mueller et al., 1990; Parmelee et al.,1990) e da biomassa microbiana do solo (Carter \& Rennier, 1982; Carter, 1986; Follett \& Schimel, 1989; Lima et al., 1994; Balota et al, 1998).

Recentes estimativas elaboradas pela Federação Brasileira de Plantio Direto na Palha (FEBRAPDP, 2003) indicam que aproximadamente 18 milhões de hectares do território brasileiro são cultivadas no SPD. A adoção desse sistema vem aumentando exponencialmente, principalmente em áreas de fronteira agrícola como no cerrado brasileiro. Entretanto, as áreas que há mais tempo adotam o SPD estão localizadas na região Sul do país, principalmente na região chamada de Campos Gerais no Paraná, que se destaca pela geração e difusão de tecnologia (Borges,1993). Essas áreas são de 
fundamental importância para os estudos que pretendem prever a dinâmica da MOS e seus compartimentos ao longo do tempo.

A biomassa microbiana do solo (BMS) é o componente vivo da MOS, excluindo as raízes ativas e os organismos maiores do que $0,2 \mathrm{~mm}$. Representa menos que 5\% da MOS e é a fração mais lábil, com o tempo de ciclagem estimado em 0,24 anos na região tropical (Paul e Voroney, 1983). Estudos sobre a quantidade e qualidade da BMS no SPD e os fatores que a influenciam ainda são escassos em solos das regiões subtropical e tropical. Existe, portanto, necessidade de gerar informações sobre a BMS nesses solos com o propósito de, num futuro próximo, utilizar o estoque de nutrientes nela contida para otimizar o uso de fertilizantes químicos. Esse é um ponto forte a ser considerado na agricultura moderna, principalmente pelo elevado custo de aquisição e aplicação dos adubos. A BMS atua como agente de transformação da MOS, no ciclo de nutrientes e no fluxo de energia, além de constituir uma fonte potencial de N, P, S, e outros nutrientes para as plantas. Entretanto, a sua quantidade e qualidade estão associadas a diversos fatores intrínsecos e extrínsecos à matriz do solo, como variações de textura num mesmo tipo de solo, efeito cumulativo desse tipo de manejo, além da qualidade e quantidade dos resíduos produzidos acima e abaixo da superfície do solo pela sequiência de culturas.

A fazenda Santa Branca no município de Tibagi (PR) é uma das pioneiras em SPD no Brasil, introduzido no início dos anos 70. Atualmente, é uma das poucas propriedades que possui áreas com histórico de diferentes anos de adoção de SPD. Está localizada sobre Latossolo derivado de arenito retrabalhado da formação Furnas e 
folhelhos da formação Ponta Grossa. Em virtude disso oferece condições ideais para o estudo de uma classe de solo com diferentes teores de argila.

Somando-se a esses fatores, considerou-se importante à complementação de outras pesquisas realizadas anteriormente nas mesmas áreas da fazenda. Duas teses de doutorado e duas dissertações de mestrado abrangendo a gênese dos solos (Sá, M., 2001), a dinâmica da matéria orgânica (Sá, J., 2001), a biomassa microbiana e a sua atividade (Venzke Filho, 1999) e a emissão de gases de efeito estufa (Siqueira-Neto, 2003), constituem um valioso banco de informações que deve ser ampliado e muito auxiliará na interpretação dos dados ora obtidos.

O estudo foi concebido com base na hipótese de que as características físicas e químicas do solo se alteram em função do acúmulo de MOS que ocorre em longo prazo após a adoção do SPD, com reflexos na BMS. A intensidade de tais alterações depende do teor de argila do solo. O ciclo das culturas determina as variações em curto prazo da biomassa microbiana através do regime de entradas de resíduos na superfície e em profundidade no solo.

Pretendeu-se comparar as variações da BMS em áreas submetidas há longo período ao plantio direto, porém diferindo em 10 anos no tempo de adoção do sistema (variações decorrentes do tempo de manejo) e na textura do solo (variações decorrentes do meio físico) nas sequiências de culturas (variações decorrentes do tipo de plantas) utilizadas na região de Campos Gerais, Tibagi (PR). Diferentes metas para alcançar esse objetivo geral foram traçadas, desenvolvidas e sua descrição constitui os capítulos 3 e 4 e desta tese: 
- $\quad$ "Biomassa microbiana em função do tempo de adoção do sistema plantio direto e da textura do solo". O objetivo foi avaliar as variações da BMS em áreas há 12 e 22 anos sob SPD e áreas com o mesmo tempo de adoção do SPD (12 anos) porém com diferentes texturas de solo nas seqüências de culturas utilizada na região de Campos Gerais, Tibagi, PR.

- "Parâmetros radiculares do milho e da soja sob sistema plantio direto e sua influência na biomassa microbiana do solo". O objetivo foi avaliar a influência das características morfológicas do sistema radicular do milho e da soja sobre a BMS em SPD. 


\section{REVISÃO DE LITERATURA}

\subsection{O Sistema Plantio Direto e a biomassa microbiana do solo}

O SPD proporciona condições favoráveis ao desenvolvimento dos microrganismos na camada superficial do solo devido a princípios como o não revolvimento do solo, a calagem, a adubação e a deposição dos resíduos das culturas na superfície. Em conseqüência disso, a BMS e a sua atividade geralmente são maiores nas camadas superficiais do solo nesse tipo de sistema quando comparado com o preparo convencional (Lynch \& Pantich, 1980; Doran, 1980; Carter \& Rennie, 1982). Os sistemas de cultivo convencionais, com maior perturbação, acarretam maior perda de MOS e, por conseqüência, diminuição da BMS (Doran, 1980). Já o SPD tende a aumentar tanto a MOS como seu compartimento microbiano, uma vez que a redução das interferências mecânicas diminui a amplitude do impacto de fatores ambientais como temperatura e precipitação.

McCarty et al (1998) observaram que mudanças a curto prazo ocorriam durante a transição de sistemas de cultivo mais intenso para SPD (três anos). Mostraram que a estratificação da matéria orgânica, mensurada como aumentos de $\mathrm{N}$ total, $\mathrm{C}$ orgânico e C e $\mathrm{N}$ microbianos, ocorreu da camada mais superficial $(0-5 \mathrm{~cm})$ para as mais profundas (5-20 cm) do solo. A mesma estratificação foi observada há 20 anos após a adoção do 
SPD. Conseqüentemente, a atividade biológica e as reservas de $\mathrm{C}$ e $\mathrm{N}$ orgânicos também estavam concentradas na superfície (aproximadamente $0-7,5 \mathrm{~cm}$ ) constituindo uma reserva potencial de nutrientes relativamente disponíveis para as plantas (Doran et al., 1998). O SPD representa, portanto, um ecossistema diferente do sistema convencional para a atividade biológica na superfície do solo.

A maior retenção de $\mathrm{C}$ e $\mathrm{N}$ orgânicos no solo sob SPD tem sido associada ao aumento da agregação das partículas do solo (Beare et al., 1994). Os agregados protegem fisicamente a MOS por formar uma barreira que isola os microrganismos do substrato, influindo também na interação da cadeia trófica e na ciclagem da BMS (Elliott \& Coleman, 1988).

Os resultados obtidos por Sá, J. (2001) em áreas há 20 anos sob SPD da fazenda Sta. Branca em Tibagi (PR), sugerem que o acúmulo de $\mathrm{C}$ orgânico nas camadas superficiais pode estar relacionado com a macroagregação, que conduz à proteção física da MOS entre os agregados. A taxa de agregação mais elevada é favorecida quando se tem adição semestral de resíduos das culturas, liberação e deposição de polissacarídeos e outras substâncias orgânicas resultantes do processo de mineralização, combinadas com ausência de revolvimento do solo. $\mathrm{O}$ autor sugere que o tempo de ciclagem do $\mathrm{C}$ e os mecanismos de proteção física de MOS sejam os principais fatores que diferenciam os resultados obtidos em solo tropicais dos solos temperados sob SPD.

Os microrganismos, aliados às raízes e à fauna do solo, são os principais agentes iniciadores da formação dos agregados (Amézketa, 1999), embora, segundo Six et al. (2002), se tenha em solos tropicais outro agente agregante com ação fisico-química na formação dos macroagregados que são as argilas 1:1 e os óxidos de Fe e Al. Na fase 
inicial da formação dos macroagregados atuam, portanto, forças de origem biológica e físico-química. Os microrganismos são classificados como agentes ligantes temporários dos agregados, pois os polissacarídeos e outras substâncias orgânicas resultantes do seu metabolismo são transientes, enquanto os materiais humificados, associados aos cátions polivalentes, são os persistentes no solo (Tisdall \& Oades, 1982).

O teor de argila também é um fator de agregação no solo, porém seu efeito é dependente da mineralogia. Considerando as características físico-químicas, as argilas 2:1 possuem maior capacidade de formação de agregados que as argilas 1:1, por exemplo. Do ponto de vista biológico, solos com alto teor de argila podem facilitar a aderência dos microrganismos, principalmente das bactérias, proteger de inimigos (nematóides), e reter os nutrientes. Por outro lado, dificultam as trocas de gases e a infiltração de água (Juma, 1993; Hassink, et al., 1993). Os fatores negativos podem, no entanto, ser amenizados com a mudança da estrutura do solo quando se emprega sistemas conservacionistas como o SPD (Juma, 1993).

O conceito do SPD está em expansão em várias regiões do mundo. Experimento realizado na região central da Argentina comparou as propriedades biológicas dos solos cultivados continuamente por seis anos com milho de forma convencional (aração e gradagem), com cultivo mínimo e sob SPD. As concentrações de C orgânico e de C-microbiano foram maiores sob SPD do que sob cultivo convencional nas camadas $0-5 \mathrm{~cm}$ devido à menor perturbação do solo. Nesse caso, os solos sob SPD foram mais eficientes na conservação do C orgânico e microbiano (Constantini et al., 1996). 
Kandeler et al. (1999) também compararam as propriedades biológicas dos solos austríacos sob diferentes formas de cultivo (convencional, mínimo e reduzido ou SPD) e observaram que a diversidade funcional (com base na atividade microbiana e enzimática) foi maior já no primeiro ano sob cultivo mínimo e sob SPD, assim permanecendo por oito anos. Tanto a BMS, a taxa de mineralização do N, o potencial de nitrificação, e a atividade enzimática (protease, xilanase e fosfatase) reagiram em velocidade diferente às mudanças do manejo do solo. A diversidade dos componentes da comunidade microbiana do solo pode ter sido uma das razões desse resultado, afetando a taxa de ciclagem do $\mathrm{C}$ microbiano e a disponibilidade dos nutrientes para a planta.

Estudo realizado no México por Salinas-Garcia et al. (2002) mostrou que o SPD alterou a distribuição e a concentração dos resíduos das culturas, do C orgânico, do C e N-microbianos, do potencial de mineralização do $\mathrm{N}$, do $\mathrm{N}$-total e do P-extraível no perfil do solo. Atribuíram a causa do fato à concentração dos resíduos na superfície do solo no SPD e cultivo mínimo, oferecendo condições ótimas para a ciclagem de nutrientes e aumento da BMS. O aumento da MOS foi considerado a mudança mais importante nesses solos. Solos cultivados de forma convencional têm a matéria orgânica distribuída de forma mais uniforme no perfil. No SPD, como já foi dito acima, ocorre uma estratificação, com a maior concentração de MOS na superfície do solo. A biomassa e os processos microbianos acompanham esse padrão e, em conseqüência, são significativamente maiores do que no sistema convencional.

Vários estudos sobre a BMS foram realizados na região leste dos Estados Unidos, local de origem do SPD na América (Ohio, Kentucky e Illinois). Doram (1980) estudou o efeito do manejo do solo na composição microbiana, comparando SPD e 
sistema convencional. Observou aumento da BMS e mudanças nos grupos funcionais como nitritadores (oxidantes de amônio), nitratadores (oxidantes de nitrito) e aumento considerável de desnitrificadores na camada 0-7,5cm. Outros autores (Lynch \& Pantich, 1980; Carter \& Rennier, 1982).também verificaram aumento da BMS em SPD em relação ao sistema convencional.

Diversos estudos sobre a BMS também vêm sendo realizados no Brasil nos últimos anos. Começaram no sul do país, região pioneira na adoção do SPD, com o grupo do professor Caio Vidor da Universidade Federal do Rio Grande do Sul. Em 1983, Silva \& Vidor (1984) avaliaram o efeito de praticas de manejo na comunidade microbiana em três localidades da região fisiográfica das Missões (RS) e verificaram que o sistema convencional não diferiu do SPD. No entanto, a rotação de culturas e o cultivo de pastagens aumentaram a comunidade bacteriana e fúngica do solo. O método empregado na avaliação da comunidade microbiana foi a da contagem em placas de Petri. Como se sabe hoje, este método é pouco preciso para estimar a BMS.

Lima et al. (1994) verificaram que em um Latossolo Vermelho escuro manejado por 14 anos em SPD m região de Ponta Grossa (PR) houve um aumento de $160 \%$ do C-microbiano na camada $0-5 \mathrm{~cm}$ em relação ao sistema convencional no mês de julho.

Balota et al. (1998) avaliaram o C e o N-microbianos e a atividade da BMS por três anos (1992 a 1995) em um experimento instalado em um Latossolo roxo distrófico com histórico de 20 anos de SPD em Londrina (PR). Os autores constataram que com a adoção do plantio direto houve um aumento no $\mathrm{C}$ e $\mathrm{N}$-microbianos de respectivamente $118 \%$ e $101 \%$ nas diversas épocas amostradas em relação ao preparo convencional. 
Na região do cerrado brasileiro Mendes et al. (2000) verificaram que na época chuvosa os níveis de Cmicrobiano da camada $0-5 \mathrm{~cm}$ de um solo cultivado com milheto e guandú sob SPD foram 1,7 e 1,5 vezes maiores que os teores dbservados no sistema convencional.

Balota et al. (2003) concluíram recentemente um estudo de longo tempo de duração em que o SPD foi comparado ao plantio convencional na estação experimental do Instituto de Agronômico do Paraná (IAPAR) em Londrina (PR). Constataram que o manejo do solo ou a rotação de culturas afeta a imobilização de nutrientes do solo. A grande quantidade de C imobilizado na forma de BMS sugere que o solo sob SPD confere maior quantidade de C-lábil à MOS do que o sistema convencional.

Como se pode observar, a maioria dos trabalhos encontrados na literatura compara a BMS no SPD com diferentes sistemas de manejo do solo. Entretanto, poucos tratam da evolução do SPD e seu impacto nas propriedades químicas, físicas e biológicas do solo. Carter \& Renner (1982) avaliaram os três tipos de propriedade em uma cronossequiência formada por áreas com 2, 4, 12 e 16 anos de plantio direto no oeste do Canadá e observaram um aumento gradual do $\mathrm{C}$ e $\mathrm{N}$ total em função do tempo de adoção e diminuição do C e N-microbianos na área mais antiga. Staley et al. (1988) estudaram uma cronossenquiência de 20 anos de plantio direto onde verificaram que houve um aumento de $35 \%$ no C-microbiano na camada $0-7,5 \mathrm{~cm}$ e de $17 \%$ na camada 7,5-15 cm em relação ao tempo zero (preparo convencional). Na cronosseqüência formada por um campo nativo, uma área de preparo convencional sobre o campo nativo e duas áreas de SPD com 10 e 20 anos, Venzke Filho (1999) verificou que o Cmicrobiano diminuiu e o $\mathrm{N}$-microbiano e a respiração basal permaneceram iguais em 
função tempo de adoção do SPD. O N-microbiano apresentou correlação positiva com o N-total e com a respiração basal do solo, ou seja, a atividade biológica do solo. Observase nos estudos acima que os teores de $\mathrm{C}$ e $\mathrm{N}$-microbiano comportaram-se diferentemente em função do tempo de adoção do SPD, provavelmente devido à influência de outros fatores sobre a microbiota e sua atividade, tais como os tratos culturais (adubação e calagem) e a sequiência de culturas.

\subsection{Efeito das raízes sobre a biomassa microbiana do solo}

A planta tem a capacidade de, através do seu sistema radicular, influenciar os microrganismos e vice-versa. O local físico no solo onde ocorre a interação entre o sistema radicular da planta com os microrganismos é chamado de rizosfera (Bolton Junior et al., 1993). O solo rizosférico tem características bem diferentes do solo mais distante das raízes (não rizosférico). A planta pode modificar a rizosfera com a mudança de $\mathrm{pH}$, de potencial redox, de concentração de íons, e com a liberação de compostos orgânicos (Rovira, 1979; Marschner, 1995). Muitos destes compostos são fontes de nutrientes ou inibidores de crescimento para os microrganismos (Curl \& Truelove, 1986).

Do ponto de vista da absorção de nutrientes, da agregação das partículas minerais e da atividade microbiológica, é desejável, que as plantas apresentem um amplo sistema radicular. Sua extensão e natureza podem variar desde raízes finas e fibrosas, comuns em gramíneas perenes, até raízes grossas, encontradas em espécies herbáceas. Em geral as raízes ocupam menos que $1 \%$ do volume da camada superficial dos solos agricultáveis (Barber, 1995). A densidade de raízes no solo varia com a 
espécie vegetal. Situa-se no intervalo de 1 a $5 \mathrm{~cm} \mathrm{~cm}^{-3}$ na camada superficial em culturas anuais, podendo chegar a $50 \mathrm{~cm} \mathrm{~cm}^{-3}$ em gramíneas com hábito perene (Barder, 1995). Murphy \& Smucker encontraram densidade de raízes no solo entre 7 e $20 \mathrm{~cm} \mathrm{~cm}^{-3}$ nas culturas de alfafa e azevém, aplicando a técnica de análise de imagens de vídeo.

A BMS depende da incorporação da MOS como fonte de energia para seu desenvolvimento. Na rizosfera, a entrada de MOS ocorre através da liberação de exsudatos, da escamação de células devido ao atrito contra as partículas minerais e da senescência dos pêlos radiculares e das raízes. $\mathrm{O}$ raio de influência do sistema radicular depende da textura do solo e da morfologia da raiz (Merckx, et al. 1986, Neergaard \& Magid, 2001). Nos solos argilosos essa influência se limita à cerca de $2 \mathrm{~mm}$ em torno das raízes, podendo ser mais abrangentes em solos arenosos.

Carvalho (1997) estudou a variação da BMC mês a mês durante um ano em solo sob SPD. O autor verificou que o índice pluviométrico, a entrada de resíduos, e a plena atividade rizosférica na fase de florescimento e enchimento de grãos foram os parâmetros que influenciaram a BMC. Pesquisadores como Lynch \& Panting (1980), Silva Filho \& Vidor (1984), Catellan \& Vidor (1990) também observaram um aumento da BMS quando a planta se encontrava nos estádios fenológicos em que há grande atividade rizosférica. É sabido que a rizosfera exerce efeito sobre a BMS por disponibilizar fontes de carbono e nitrogênio facilmente assimiláveis (Griffin et al, 1976).

Mello Ivo \& Mielniczuk (1999) estudaram o efeito de três métodos de preparo de solo (convencional, reduzido com escarificação e plantio direto) sobre a morfologia 
das raízes de milho. Observaram no plantio direto que as raízes apresentaram maior diâmetro médio nas camadas $10-15 \mathrm{~cm}$ e $25-35 \mathrm{~cm}$ e maior densidade de comprimento das raízes na camada de 0 a $5 \mathrm{~cm}$; enquanto que, no preparo convencional a maior concentração de raízes ocorreu entre os 10 e $15 \mathrm{~cm}$ de profundidade no final do ciclo. Esses autores atribuíram esses resultados devido ao fato de ocorrer no SPD uma camada rígida (compactada) abaixo da superfície $(5 \mathrm{~cm})$ no solo analisado e de haver maior umidade e maior concentração de nutrientes na superfície.

A entrada de MOS através do sistema radicular é expressiva. Evidentemente há variações entre as espécies vegetais, porém no geral, as gramíneas incorporam mais material que as leguminosas. Um recente estudo mostra que as raízes contribuem muito mais com o aumento do carbono orgânico no solo que os resíduos das culturas no SPD (Gale \& Cambardella, 2000).

O SPD fundamenta-se na rotação de culturas. Entretanto, cada cultura tem característica intrínseca de morfologia e atividade fisiologia das raízes, o que poderá resultar em efeito diferenciado sobre a BMS. É evidente a falta de conhecimento do efeito da distribuição, da morfologia e da fisiologia das raízes e suas interações complexas com o ambiente físico, químico e biológico do solo sob SPD, especialmente com relação a BMS. 


\section{BIOMASSA MICROBIANA EM FUNÇÃO DO TEMPO DE ADOÇÃO DO SISTEMA PLANTIO DIRETO E DA TEXTURA DO SOLO}

\section{Resumo}

Visando elucidar a dinâmica do C e $\mathrm{N}$-microbiano em solos sob sistema plantio direto (SPD), foram avaliados nas seqüências milho - trigo - soja e soja -trigo - soja cultivadas em solos com diferentes classes texturais e tempos de adoção do sistema plantio direto na fazenda Santa Branca, Tibagi (PR). O experimento foi instalado em quatro áreas, sendo três com histórico de 12 anos sob SPD, com textura muito argilosa (PD12-TmuA), argilosa (PD12-TA), e média argilosa (PD12-TmeA); e uma com histórico de 22 anos sob SPD com textura argilosa (PD22-TA). No período de 18 meses foram realizadas nove amostragens de solo em quatro camadas $(0-2,5 ; 2,5-5 ; 5-10 ; 10-$ $20 \mathrm{~cm}$ ). Em função do tempo de adoção do SPD ocorreram diferenças no C-microbiano entre o PD12-TA e o PD22-TA nas camadas mais profundas do solo. O PD22-TA apresentou em média $30,8 \mathrm{~kg} \mathrm{~N}$ mic $\cdot \mathrm{ha}^{-1}$ a mais que PD12-TA e menores variações nas quantidades de $\mathrm{N}$-microbiano na camada $0-20 \mathrm{~cm}$. Não foi possível concluir se existe efeito das sequiências de culturas empregadas nos teores de $\mathrm{C}$ e $\mathrm{N}$-microbiano devido a fatores incontroláveis que impossibilitaram uma interpretação dos resultados com respaldo estatístico. No que se refere à textura do solo, o PD12-TmuA apresentou as 
maiores médias de $\mathrm{C}$ e $\mathrm{N}$-microbiano na camada $0-20 \mathrm{~cm}$, exceto $\mathrm{os} 20$ dias após o plantio do trigo (jun/01). O PD12-TA e o PD12-TmeA não apresentaram diferenças significativas nas quantidades de C-microbiano em qualquer dos meses analisados, na camada de 0-5cm, as diferenças ocorreram nas camadas de 510 e 10-20 cm. O Cmicrobiano apresentou melhor correlação com o $\mathrm{N}_{-\mathrm{NH}_{4}{ }^{+} \text {e }}$ o $\mathrm{N}_{-\mathrm{NO}_{3}}^{-}$que o $\mathrm{N}-$ microbiano, independente da textura, do tempo de adoção SPD e da sequiência de culturas. Pode-se concluir que em função do tempo de adoção do SPD o C-microbiano aumenta em profundidade e o N-microbiano apresenta menor variação na camada 020 cm. A quantidade de C e N-microbiano é influenciada pela textura do solo. Entretanto, os solos de classes texturais próximas sob SPD podem apresentar quantidades iguais de C-microbiano na camada $0-5 \mathrm{~cm}$.

\section{Summary}

In order to elucidate the dynamics of microbial- $\mathrm{C}$ and $\mathrm{N}$ in soils under the no-tillage system (NTS), the microbial biomass was estimated in the crop sequences corn/wheat/soybean and soybean/wheat/soybean cultivated in soils with different textural classes and different time since NT adoption, at "Fazenda Santa Branca", Tibagi, Paraná State, Brazil $\left(50^{\circ} 23^{\prime} \mathrm{W}\right.$ and $\left.24^{\circ} 36^{\prime} \mathrm{N}\right)$. The experiment was implemented in four sites, three of them 12 years under NTS, with the following textural classes: Clay (PD12-TmuA), Sandy clay (PD12-TmeA), and Sandy clay loam (PD12-TA); and one site 22 years under NTS with Sandy clay loam textural class (PD22-TA). During a period of 18 months, nine soil samplings were accomplished in four depths (0-2,5; 2,5-5; 
5-10 and 10-20 cm depth). The time since NTS adoption caused differences in the microbial-C between PD12-TA and PD22-TA in the deepest soil layers. PD22-TA presented on average $30,8 \mathrm{~kg} \mathrm{~N} \mathrm{Nic} \cdot \mathrm{ha}^{-1}$ more than PD12-TA, and had the smallest range of microbial-N in the $0-20 \mathrm{~cm}$ soil layer. It was not possible to identify the crop sequences effect in the amounts of microbial- $\mathrm{C}$ and $\mathrm{N}$, due to uncontrollable factors that made it impossible to interpret the results with statistic support. PD12-TmuA presented the highest averages of microbial-C and $\mathrm{N}$ in the $0-20 \mathrm{~cm}$ soil layer, except during the 20 days after wheat seeding (jun/01). PD12-TA and PD12-TmeA did not present significant differences of microbial-C in any evaluated period in the $0-5 \mathrm{~cm}$ soil layer, but differences were observed in the deeper 5-10 and $10-20 \mathrm{~cm}$ layers. Microbial-C presented better correlation with $\mathrm{N}-\mathrm{NH}_{4}{ }^{+}$and $\mathrm{N}-\mathrm{NO}_{3}{ }^{-}$than microbial-N, independent of soil texture, time since NTS adoption or crop sequence. It can be concluded that microbial-C increases in depth with time since NTS adoption, and microbial-N presents smaller variation range in the $0-20 \mathrm{~cm}$ soil layer. The amount of microbial- $\mathrm{C}$ and $\mathrm{N}$ is influenced by soil texture. However, the soils with near textural classes under NT can present equal amounts of microbial-C in the $0-5 \mathrm{~cm}$ soil layer during the crop yield system.

\subsection{Introdução}

Sistemas de cultivo com menor perturbação do solo, como o sistema plantio direto (SPD), tendem ao aumento da matéria orgânico do solo (MOS) com o tempo de adoção (Staley, et al. 1988; Havlin et al., 1990; Carter, 1992, Cambardella \& Elliot, 
1992; Bayer \& Bertol, 1999; Rhoton, 2000; Sá, J. 2001), e conseqüentemente da biomassa microbiana do solo (BMS) (Staley, et al. 1988; Beare et al., 1994; Balota et al. 1998; Valpassos et al., 2001), que estando mais protegida, é afetada em menor intensidade por variações ambientais (Blevins et al., 1977; Wardle,1997).

A BMS, por ter ação catalítica sobre a MOS, é a chave que controla os processos de mineralização-imobilização dos nutrientes no solo. Por esta razão ela é um dos principais componente dos modelos de ciclagem de nutrientes (Paul, 1984; Veen et al., 1984), e potencialmente um dos indicadores para recomendação de fertilizantes industrializados, principalmente os nitrogenados (Sparling e Ross, 1993). Entretanto, não está claro se a quantidade de BMS pode fornecer uma dimensão da taxa de mineralização da MOS, como sugerido por Parkinson \& Paul (1982). Resultados obtidos por Puri \& Ashman (1998) mostram que somente uma parte da biomassa microbiana está ativa e envolvida com a mineralização do N. Segundo Duxbury et al. (1991), o Nmineral, $\mathrm{N}$-mineralizável e a $\mathrm{N}$-microbiano são compartimentos do $\mathrm{N}$-ativo, devido à participação dos mesmos no processo de mineralização-imobilização do N. Através de técnica de diluição isotópica, McCarty et al. (1995) mostraram que a N-microbiano tem uma alta correlação $(r=0,96)$ com $\mathrm{N}$-ativo. Sendo o $\mathrm{N}$-mineral um importante compartimento do processo de mineralização-imobilização do $\mathrm{N}$ no solo, cabe estudar a sua relação com a biomassa microbiana.

A quantidade e a composição da BMS são influenciadas por diversos fatores: o tempo de adoção do sistema de cultivo; a rotação de culturas e a textura do solo. Com o passar do tempo ocorrem alterações nas propriedades físicas, químicas e biológicas do 
solo sob SPD. Dick et al. (1991) mostraram que as alterações nas propriedades do solo sob SPD em Ohio - EUA são detectadas nos primeiros 10 anos de adoção e que é difícil ser detectado nos primeiros anos (2 ou 3 anos). Já Rhoton (2000) observou que nos primeiros quatros anos de SPD ocorreram alterações nas propriedades relacionadas a erodibilidade e fertilidade, demonstrando a sustentabilidade do sistema. Sá, J. (2001) verificou em Latossolo Vermelho sob SPD melhora nas propriedades químicas e aumento da fertilidade do solo com carga variável ao longo tempo de adoção.

A rotação de culturas é uma das características essenciais do SPD, sendo que o seu uso é recomendado por aumentar a estabilidade dos agregados do solo (Bruce et al. 1990; Amézketa, 1999), além de disponibilizar mais C ao solo quando é cultivada uma gramínea ou fixar $\mathrm{N}$ atmosférico quando é cultivada uma leguminosa. Tais efeitos têm a capacidade de influenciar a disponibilidade de nutrientes para a cultura subseqüente (Amado et al., 1998). A influência de determinada planta sobre a BMS pode ser direta, como no caso do efeito seletivo da rizosfera (Neal, et al., 1973) ou indireta, por meio da diversificação das fontes de $\mathrm{C}$ nos resíduos culturais, que podem ser mais ou menos susceptíveis à decomposição enzimática pelos microrganismos (Herman et al., 1977; Struwe \& Kjđler, 1985; Rahn \& Lillywhite, 2001). A maioria dos produtores da região sul do Brasil adota na rotação a sequiência de culturas: milho ou soja no verão e aveia ou trigo no inverno. A literatura conta com poucos estudos que abordam o efeito dessas seqüências sobre a BMS sob SPD. O uso de práticas conservacionistas destaca-se por recuperar gradativamente o teor MOS, o que se reflete no aumento do tamanho dos agregados, ou seja, promove a proteção física das moléculas orgânicas (Six et al. 2002). 
Maior proteção física da MOS foi comprovada em solos com textura fina em comparação com os de textura grossa, resultando em maiores teores de $\mathrm{C}$ e de BMS (Jenkinson, 1988; Amado \& Ladd, 1992; Hassink, 1994).

Com o propósito de elucidar algumas das inter-relações da BMS com as características extrínsecas e intrínsecas à matriz do solo, esse estudo se propõe a avaliar as variações dos teores de $\mathrm{C}$ e $\mathrm{N}$ microbiano do solo sob a influência do tempo de adoção do SPD e da textura do solo, correlacionando-os com o $\mathrm{N}$ mineral (amônio e nitrato) do solo nas seqüências de culturas adotadas na região subtropical do Sul do Brasil.

\subsection{Material e Métodos}

\subsubsection{Seleção e localização das áreas de estudo}

A pesquisa foi desenvolvida na Fazenda Santa Branca $\left(24^{\circ} 36^{\prime} \mathrm{S}\right.$ e $\left.50^{\circ} 23^{\prime} \mathrm{O}\right)$, município de Tibagi (PR) (Figura 1). Foram selecionadas 4 áreas, sendo três das áreas diferencia- se pela classe textural e a outra pela época de adoção do SPD (Tabela 1).

\subsubsection{Caracterização edafo-climática da região}

A fazenda Santa Branca encontra-se na transição entre dois materiais de origem, o folhelho de formação Ponta Grossa, que possui textura muito argilosa e o arenito de formação Furnas, de textura média. O solo da região é classificado como um latossolo vermelho - escuro derivado de material retrabalhado de rochas sedimentares do período devoniano (Sá, M., 2001). 


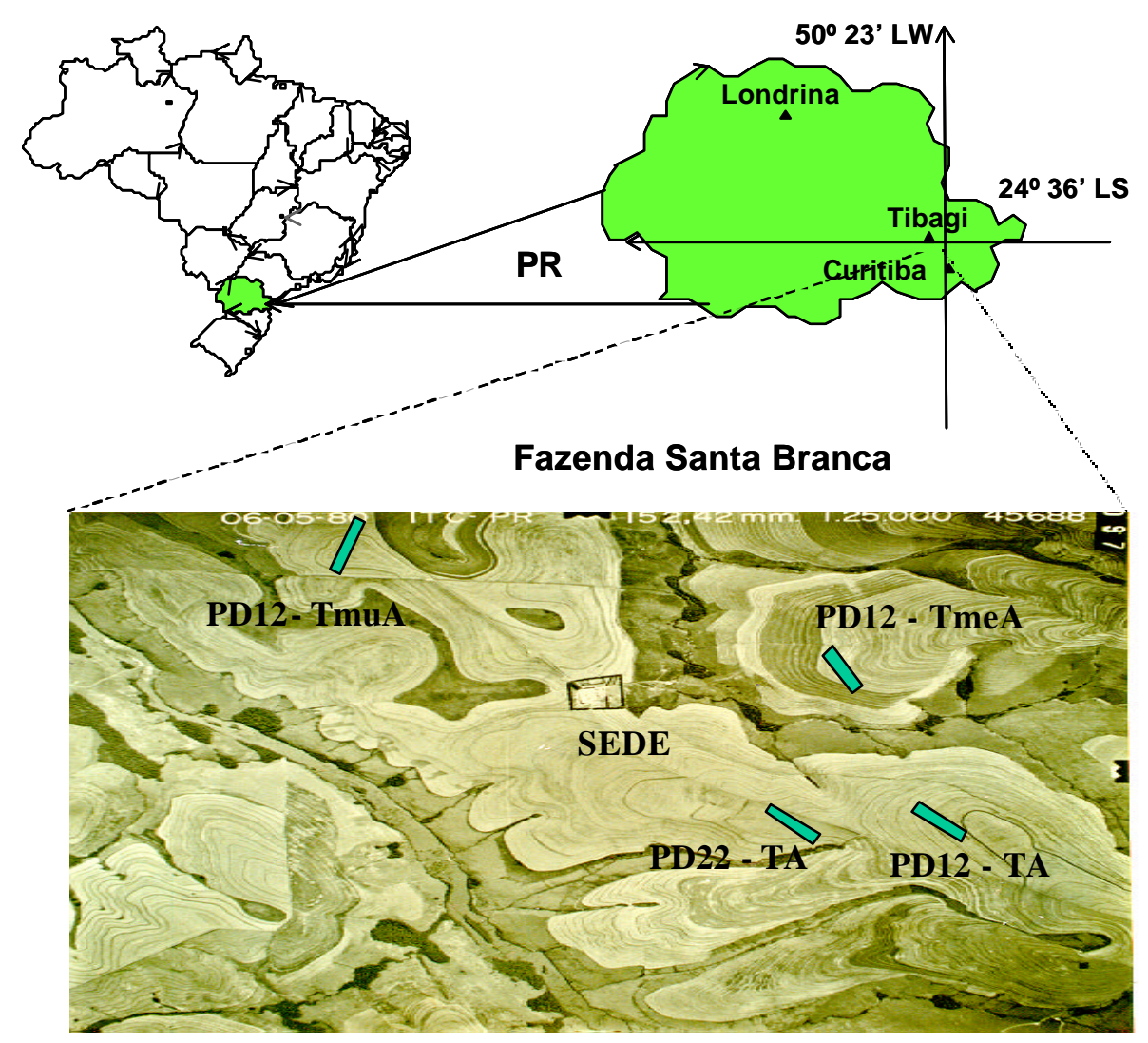

Figura 1 - Localização das áreas de estudo na Fazenda Santa Branca, município de Tibagi (PR)

Tabela 1. Código das áreas selecionadas em função do tempo de adoção do sistema de plantio direto (SPD) e da classe textural

\begin{tabular}{ccc}
\hline Código & Tempo de Adoção do SPD & Classe Textural \\
\hline PD22-TA & 22 anos & Textura argilosa \\
PD12-TA & 12 anos & Textura argilosa \\
PD12- TmeA & 12 anos & Textura média argilosa \\
PD12- TmuA & 12 anos & Textura muito argilosa \\
\hline
\end{tabular}


O relevo é suave ondulado com pendentes longas, a ondulado, cortado pela escarpa devoniana. As altitudes variam entre $1.150 \mathrm{~m}$ na testa da Formação Furnas a 800m no vale do rio Tibagi, com 910m nas áreas de estudo. A composição florística original é composta de gramíneas baixas, desprovidas de arbusto, ocorrendo apenas matos ou capões limitados ás depressões em torno das nascentes (Maack, 1981). O termo usual para a denominação desse tipo de vegetação é Campos Gerais.

O clima de acordo com a classificação de Koeppen é do tipo cfb, clima temperado, com verões frescos, geadas severas e freqüentes no inverno, com temperatura média no mês mais quente (janeiro) inferior a $22^{\circ} \mathrm{C}$ e do mês mais frio (julho) de $18^{\circ} \mathrm{C}$. A precipitação média anual é de $1.700 \mathrm{~mm}$, sem estação seca definida (Instituto Agrônomico do Paraná, 1994). A temperatura média e a precipitação acumulada mensal observada durante o período das amostragens estão representadas na figura 2.

Temperatura e precipitação média mensal

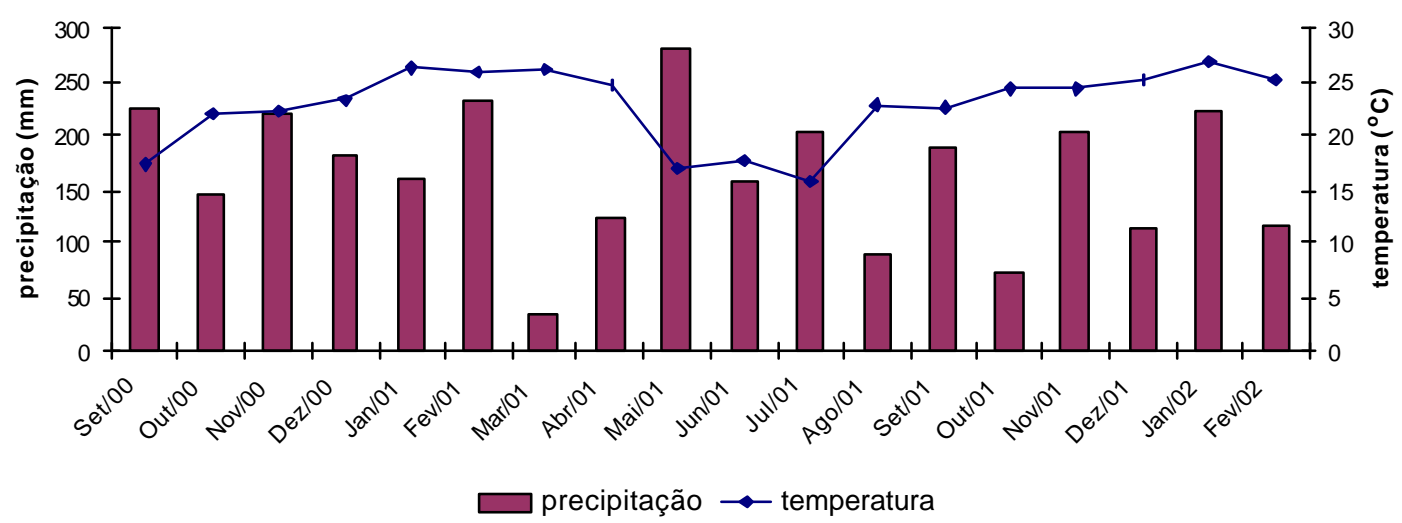

Figura 2 - Temperatura média e precipitação acumulada mensal de setembro de 2000 a fevereiro de 2002. Fonte: Cooperativa Batavo e Fundação ABC 


\subsubsection{Histórico do uso das áreas}

A Fazenda Santa Branca iniciou suas atividades agrícolas no ano de 1959, porém as áreas selecionadas para a pesquisa permaneceram intocadas até 1969, quando começaram a ser exploradas no sistema de plantio convencional (uma aração e duas gradagens). Nos três primeiros anos foram cultivadas com arroz de sequeiro (Oriza sativa L.) A acidez foi corrigida com calcário dolomítico (PRNT 85\%) e a deficiência de $\mathrm{P}$ foi corrigido com a adição $117 \mathrm{~kg} \mathrm{ha}^{-1}$ de $\mathrm{P}_{2} \mathrm{O}_{5}(52 \mathrm{~kg} \mathrm{P})$ no primeiro ano de cultivo. Em seguida foram cultivadas no binômio soja (Glicine max (L.) Merr) - trigo (Triticum aestivum L.)(soja no verão e trigo no inverno) por 7 anos. Em 1979, 20 a 30\% da área total da fazenda foi convertida para o SPD (Figura 3). Parte dessa área é representada pelo tratamento PD22.

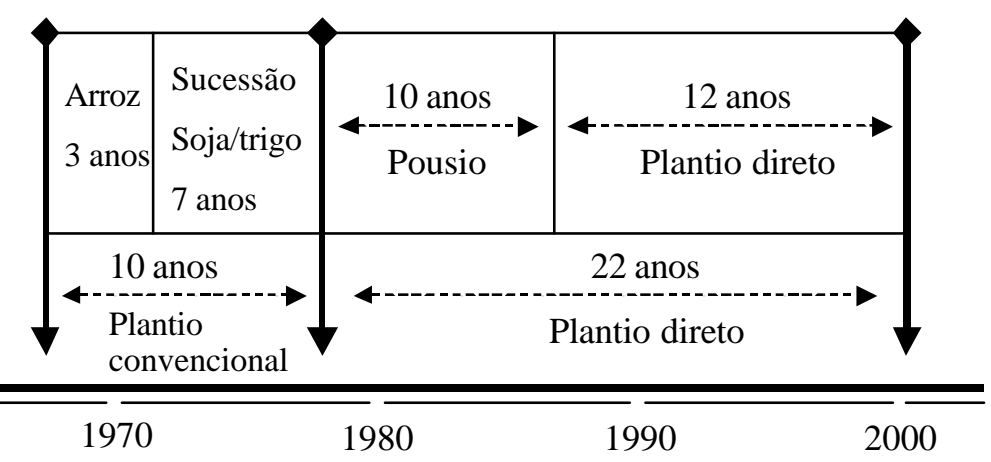

Figura 3 - Representação gráfica do histórico de ocupação agrícola da área pertencente à Fazenda Santa Branca, com destaque para as áreas de estudo

De 1979 a 2001 foram cultivados ali 16 ciclos de soja e 6 de milho (Zea mays L.) no verão e 7 ciclos de trigo no inverno, intercaladas com 12 de aveia - preta (Avena strigosa Schreb.) e 2 de tremoço como cobertura verde. O SPD foi expandido para áreas 
contíguas em 1989, representando o tratamento PD12. A área recebeu desde então 7 ciclos de soja e 5 de milho no verão e 5 ciclos de trigo e 6 de aveia preta no inverno.

\subsubsection{Caracterização física e química do solo das áreas}

Com as amostras de solo das primeiras coletas (setembro e outubro de 1999) foram realizadas análises físicas e químicas como objetivo de caracterizar as áreas de estudos. (Tabelas 2,3 e 4) As análises foram realizadas no laboratório do departamento de solos e nutrição de plantas da Esalq - USP, exceto densidade do solo que foi determinada no laboratório de biogeoquímica ambiental do CENA - USP.

A análise granulométrica foi realizada em três amostras de cada área de estudo. Com objetivo de diminuir a influência da MOS no método empregado, utilizou-se amostras da camada de $10-20 \mathrm{~cm}$. O método utilizado foi da pipeta, com dispersante (Camargo et al., 1986).

Tabela 2. Caracterização granulométrica das áreas

\begin{tabular}{cccc}
\hline Áreas & Areia & Silte & Argila \\
\cline { 3 - 4 } PD22 - TA & 50 & 8 & 42 \\
PD12 - TA & 42 & 8 & 40 \\
PD12 -TmuA & 13 & 15 & 72 \\
PD12 - TmeA & 65 & 8 & 27 \\
\hline
\end{tabular}

A densidade do solo foi determinada pelo método do anel volumétrico (Blake \& Hartge, 1986). Para isso, foram coletadas, com anéis volumétricos $(4,85 \mathrm{~cm}$ de 
diâmetro e 2,5 ou 5,0 cm de altura), seis amostras, três em cada subárea, por camada de interesse $(0-2,5 ; 2,5-5 ; 5-10$ e $10-20 \mathrm{~cm})$, totalizando 96 amostras.

Tabela 3. Densidade do solo

\begin{tabular}{lcccc}
\hline \multicolumn{1}{c}{ Profundidade } & PD22 - TA & PD12-TA & PD12-TmuA & PD12- TmeA \\
\cline { 3 - 5 } & 1,16 & 1,24 & 1,10 & 1,28 \\
\cline { 2 - 5 } $0-2,5 \mathrm{~cm}$ & 1,36 & 1,40 & 1,15 & 1,42 \\
$2,5-5 \mathrm{~cm}$ & 1,35 & 1,44 & 1,03 & 1,55 \\
$5-10 \mathrm{~cm}$ & 1,36 & 1,45 & 1,03 & 1,48 \\
$10-20 \mathrm{~cm}$ & & & & \\
\hline
\end{tabular}

A metodologia utilizada para as análises químicas foi descrita por Raij et al. (1987). $\mathrm{O} \mathrm{pH}$ foi determinado em água; $\mathrm{KCl}$ a $1 \mathrm{~mol} \mathrm{~L}^{-1}$ e $\mathrm{CaCl}_{2} 0,01 \mathrm{~mol} \mathrm{~L}^{-1}$, na proporção solo: solução de 1:2,5. Os cátions básicos trocáveis e o $\mathrm{P}$ disponível foram extraídos com a solução extratora de Melich-3 (Melich, 1984). Os teores de $\mathrm{Ca}^{2+}, \mathrm{Mg}^{2+}$ foram determinados em espectrometria de chama de emissão; e o P por colorimetria em um espectrofotômetro a 660 nm, após reação com molibdato de amônio e cloreto de estrôncio.

$\mathrm{O} \mathrm{Al}^{3+}$ trocável foi extraído com $\mathrm{KCl} 1 \mathrm{~mol} \mathrm{~L}^{-1}$, agitando - se $5 \mathrm{~g}$ de terra com 50 $\mathrm{mL}$ da solução por 15 minutos. O extrato obtido ficou em repouso durante 24 horas. Uma alíquota de $25 \mathrm{~mL}$ do líquido sobrenadante foi usada para determinação do $\mathrm{Al}^{3+}$ por titulometria com uma solução padronizada de $\mathrm{NaOH} 0,025 \mathrm{~mol} \mathrm{~L}^{-1}$, usando-se azul de bromotimol como indicador. A acidez potencial $\left(\mathrm{H}^{+}+\mathrm{Al}^{3+}\right)$ foi determinada por 
titulometria, após a extração com solução de acetato de cálcio 2 mol L $\mathrm{L}^{-1}$ tamponado a pH 7,0 .

A soma de bases $(\mathrm{SB})$ foi calculada pela formula: $\mathrm{SB}=\mathrm{Ca}+\mathrm{Mg}+\mathrm{K}$; a capacidade de troca de cátions (CTC) foi determinada pela soma de SB mais acidez potencial $\left(\mathrm{T}=\mathrm{SB}+\left(\mathrm{H}^{+}+\mathrm{Al}^{3+}\right)\right)$; por último, a saturação por base $(\mathrm{V})$ foi pela formula: $\mathrm{V}=100(\mathrm{SB} / \mathrm{CTC})$ 
Tabela 4. Caracterização química das áreas em estudo

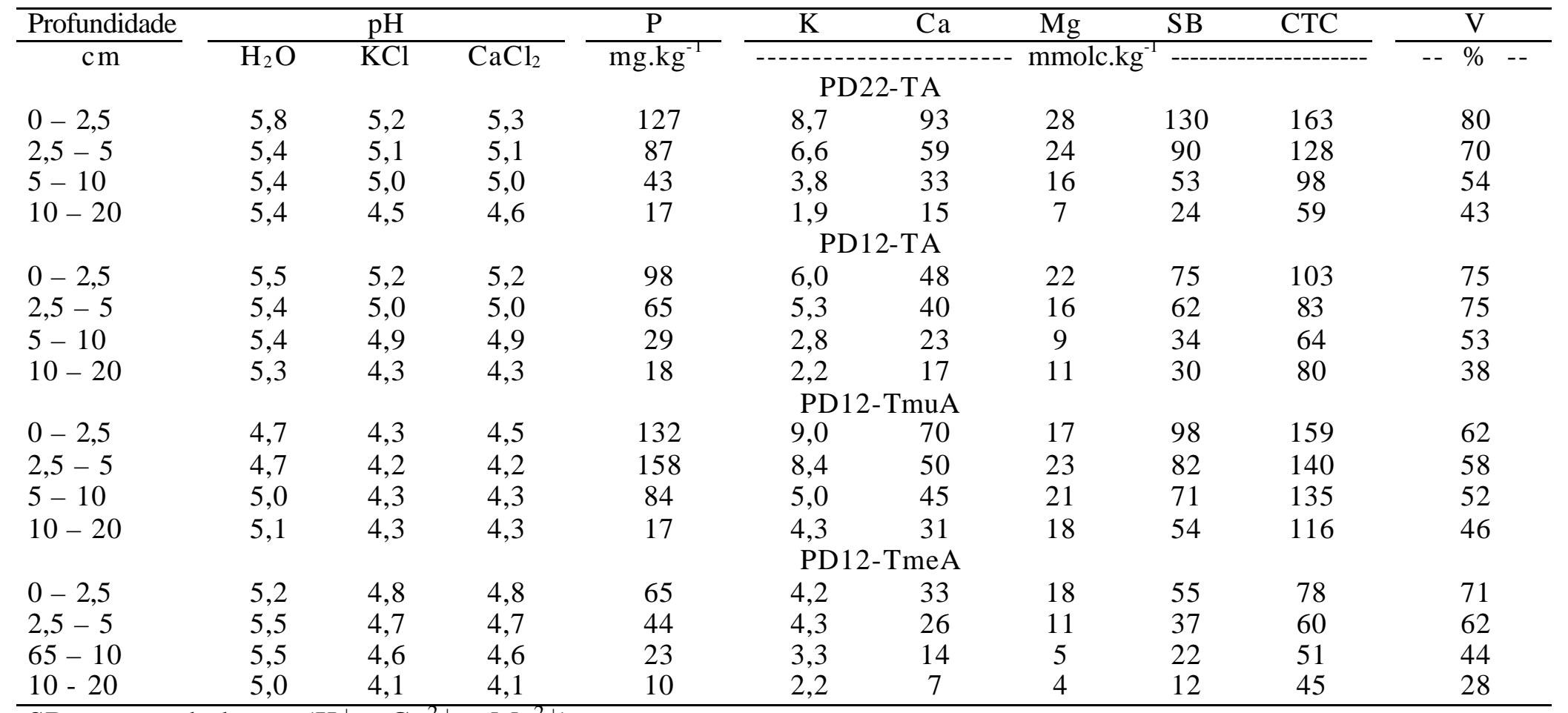

$\mathrm{SB}=$ soma de bases $\left(\mathrm{K}^{+}+\mathrm{Ca}^{2+}+\mathrm{Mg}^{2+}\right)$.

$\mathrm{V} \%=$ Porcentagem de saturação de bases da CTC a pH =7,0. 


\subsubsection{Instalação, condução e épocas de amostragem do experimento}

O experimento foi instalado em 23 de setembro de 2000 nas áreas PD12-TA e PD22-TA, e no mês seguinte nas áreas PD12-TmuA, PD12-TmeA. Nas ocasiões todas as áreas tinham restevas de aveia - preta. A área experimental de cada tratamento foi delimitada com estacas, num total de $1400 \mathrm{~m}^{2}$, subdivididos em dez sub-áreas de $35 \mathrm{~m} \mathrm{x}$ 40m (Figura 4). A sucessão milho - trigo - soja foi estuda em cinco sub-áreas e a sucessão soja - trigo - soja nas outras cinco.

Em cada sub-área foram coletadas cinco amostras nas profundidades $0,0-2,5 ; 2,5-$ 5,0; 5,0-10,0; 10,0-20,0 cm formando uma amostra composta (repetição), totalizando 5 amostras por tratamento em cada uma das profundidades.

As coletas de solo foram realizadas em 9 diferentes épocas (Figura 5) na sucessão A e 8 na sucessão B. Na primeira coleta foi amostrada a área total, devido à homogeneidade do manejo de cada área. Os tratos culturais nas sub-áreas estão descridos na na tabela 5.

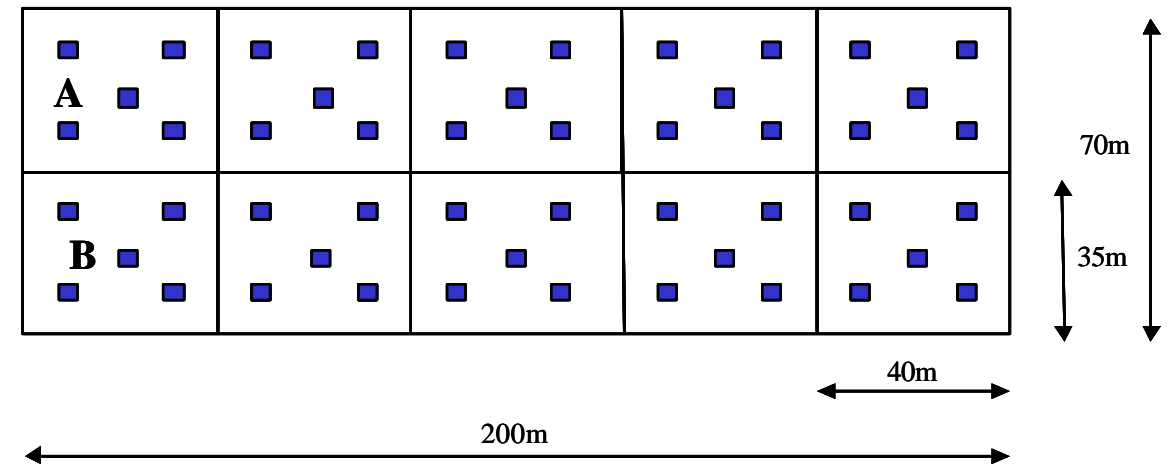

A - Sucessão aveia-preta/milho/trigo/soja Sub-amostras de solo

B - Sucessão aveia-preta/soja/trigo/soja

Figura 4 - Esquema dos pontos de coleta de solo 
Tabela 5. Época de amostragem do solo, resíduos e cultura presentes no momento da coleta, tratos culturais aplicados no período entre coletas, e o último trato cultural realizado antes da coleta nas áreas estudadas (Fonte Fazenda Santa Branca, Tibagi,PR)

\begin{tabular}{|c|c|c|c|c|c|}
\hline Época & Resíduos/Cultura & Tratos culturais e datas de suas oco & rrências & Coleta na seqüência $A$ & Coleta na seqüência $B$ \\
\hline Set/00 & $\begin{array}{l}\text { Resíduos de aveia preta/ sem } \\
\text { cultura }\end{array}$ & $\begin{array}{l}\text { Herbicida (glifosate) + inseticida em todas as } \\
\text { áreas. } \\
\text { Plantio do milho (Cargil 909) e adubação } \\
\left.\text { NPK ( } 250 \mathrm{~kg} \mathrm{ha}^{-1} 15-18-09\right)+0,75 \% \text { de } \\
\text { Sulfato de Zinco }\end{array}$ & $\begin{array}{c}\cdots \\
27 / 09 / 00\end{array}$ & $\begin{array}{l}\text { Anterior à aplicação } \\
\text { do herbicida }\end{array}$ & $\begin{array}{l}\text { Anterior à aplicação } \\
\text { do herbicida }\end{array}$ \\
\hline Out/00 & $\begin{array}{l}\text { Resíduos de aveia preta / milho em } \\
\text { fase vegetativa }\end{array}$ & $\begin{array}{l}\text { Adubação cobertura no milho }\left(200 \mathrm{~kg} \mathrm{ha}^{-1}\right. \\
\text { sulfato de amônia) } \\
\text { Herbicida }+ \text { inseticida no milho } \\
\text { Plantio da soja (Embrapa 59) e adubação PK } \\
\left(200 \mathrm{~kg} \mathrm{ha}^{-1} \text { super simples e } 150 \mathrm{~kg} \mathrm{ha}^{-1} \mathrm{KCl}\right)\end{array}$ & $\begin{array}{l}15 / 10 / 00 \\
24 / 10 / 00 \\
25 / 10 / 00\end{array}$ & 15 dias após plantio & $\mathrm{nc}$ \\
\hline Nov/00 & $\begin{array}{l}\text { Resíduos de aveia preta / milho e } \\
\text { soja em fase vegetativa }\end{array}$ & - & & $\begin{array}{l}1 \text { mês após adubação } \\
\text { do milho }\end{array}$ & $\begin{array}{l}20 \text { dias após plantio da } \\
\text { soja }\end{array}$ \\
\hline Fev/01 & $\begin{array}{l}\text { Resíduos de aveia preta / milho e } \\
\text { soja fase de maturação }\end{array}$ & $\begin{array}{l}\text { Colheita do milho } \\
\text { Colheita da soja }\end{array}$ & $\begin{array}{l}10 / 03 / 01 \\
11 / 04 / 01\end{array}$ & Anterior à colheita & Anterior à colheita \\
\hline Maio/01 & $\begin{array}{l}\text { Resíduos de milho ou de soja /sem } \\
\text { cultura }\end{array}$ & $\begin{array}{l}\text { Aplicação de herbicida + inseticida em todas } \\
\text { as áreas. }\end{array}$ & $\ldots$ & $\begin{array}{l}\text { Anterior à aplicação } \\
\text { do herbicida }\end{array}$ & $\begin{array}{l}\text { Anterior à aplicação } \\
\text { do herbicida }\end{array}$ \\
\hline $\mathrm{Jun} / 01$ & $\begin{array}{l}\text { Resíduos de milho ou de soja / } \\
\text { trigo em fase vegetativa }\end{array}$ & $\begin{array}{l}\text { Plantio do trigo (OR 1 - Melhoramentos) e } \\
\text { adubação NP }\left(200 \mathrm{~kg} \mathrm{ha}^{-1} \mathrm{DAP} 18 \% \mathrm{~N}^{2} 46 \% \mathrm{P}_{2} \mathrm{O}_{5}\right) \\
\text { Adubação de cobertura NK }\left(200 \mathrm{~kg} \mathrm{ha}^{-1} 30-\right. \\
00-20)\end{array}$ & $\begin{array}{l}04 / 06 / 01 \\
07 / 07 / 01\end{array}$ & $\begin{array}{l}20 \text { dias após plantio } \\
\text { do trigo }\end{array}$ & $\begin{array}{l}20 \text { dias após plantio do } \\
\text { trigo }\end{array}$ \\
\hline Ago/01 & $\begin{array}{l}\text { Resíduos de milho ou de soja / } \\
\text { trigo em fase reprodutiva }\end{array}$ & Aplicação de herbicida + inseticida & $\ldots$ & 50 dias após adubação & 50 dias após adubação \\
\hline Out/01 & Resíduos de trigo / sem cultura & $\begin{array}{l}\text { Colheita do trigo } \\
\text { Aplicação de herbicida e inseticida } \\
\text { Plantio da soja (FT Ibiara) e adubação PK } \\
\left(200 \mathrm{~kg} \mathrm{ha}^{-1} \text { super simples e } 150 \mathrm{~kg} \mathrm{ha}^{-1} \mathrm{KCl}\right)\end{array}$ & $\begin{array}{c}23 / 10 / 01 \\
\ldots \\
10 / 11 / 01\end{array}$ & 1 dia após colheita & 1 dia após colheita \\
\hline Fev/02 & $\begin{array}{l}\text { Resíduos de trigo / soja inicio da } \\
\text { fase de maturação }\end{array}$ & 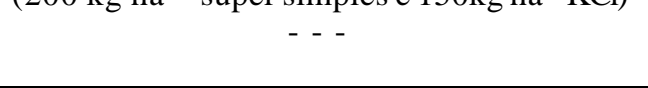 & & $\begin{array}{l}90 \text { dias após plantio } \\
\text { da soja }\end{array}$ & $\begin{array}{l}90 \text { dias após plantio da } \\
\text { soja }\end{array}$ \\
\hline
\end{tabular}




\subsubsection{Procedimento de coletas e armazenamento de amostras de solo.}

Após a retirada dos resíduos culturais da superfície do solo, amostras das camadas $0-2,5 \mathrm{~cm}$ e $2,5-5 \mathrm{~cm}$ foram coletadas com auxílio de espátulas e réguas graduada. Nas camadas $5-10 \mathrm{~cm}$ e $10-20 \mathrm{~cm}$, as amostras foram coletas com sonda de 2,5 de diâmetro (Figura 5). As sub-amostras de cada repetição foram colocadas em baldes plásticas para serem homogeneizadas e em seguida divididas em sacos de plásticos para serem encaminhadas para as devidas análises. Ao chegarem no laboratório as amostras de solo passaram por uma peneira de $4 \mathrm{~mm}$ para retirada de pedras e raízes grossas. As amostras para determinação de BMS foram armazenadas em câmara fria a $4^{\circ} \mathrm{C}$ até o processamento das análises.

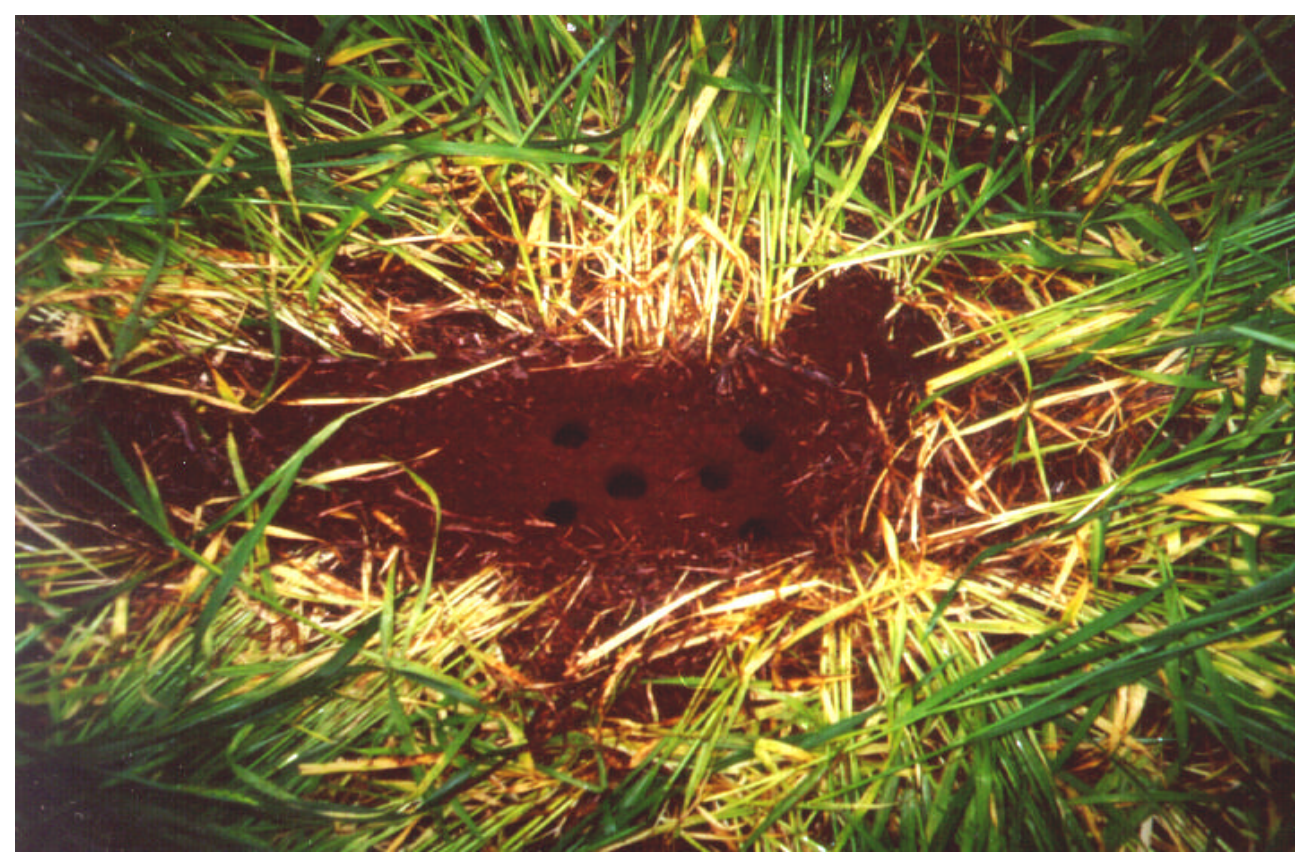

Figura 5- Foto da amostragem de solo 


\subsubsection{Determinação da concentração de amônio e nitrato}

Amônio e nitrato foram extraídos do solo com $50 \mathrm{~mL}$ de $\mathrm{KCl} 2 \mathrm{~mol} \mathrm{~L}^{-1}$. O conjunto extrator e amostra do solo foram agitados manualmente no início e seguida deixado em repouso por 24h. Após foi realizado a filtragem com filtros Whatman in 42 . Os extratos foram preservados com difenil-acetado de mercúrio. Os teores de amônio foram determinados pelo método de Solorzano com um sistema automático de fluxo contínuo (FIA) acoplado a um condutivímetro. Os teores de nitrato foram quantificados na forma de nitrito, após redução com o catalisador cádmio e leitura colorimétrica em sistema FIA (Ruzicka \& Hansen, 1981).

\subsubsection{Determinação do teor de $\mathrm{C}$ e $\mathrm{N}$ total do solo}

O carbono e nitrogênio total do solo foram determinados por combustão a seco em autoanalisador CN-2000 da LECO em amostras secas ao ar, moídas e peneiradas a 100 meshes.

\subsubsection{Determinação do C e $\mathrm{N}$ microbiano}

\section{- C - microbiano}

O C - microbiano foi determinada pelo método de fumigação-extração (FE) (Brookes et al., 1985 e Vance et al., 1987 ) pois esse método é considerado o mais indicado para solos ácidos com recente incorporação de restos vegetais (Brookes et al., 1985; Vance \& Jenkinson, 1987).

As amostras de solo, conservadas inicialmente em câmara fria, foram peneiradas (malha $4 \mathrm{~mm}$ ) para retirada das raízes maiores e incubadas em temperatura ambiente por quatro dias. Determinada a umidade, ajustou-se o valor para $50 \%$ da capacidade de retenção de água, quando necessário. 
Duas subamostras de solo úmido, pesando o equivalente a $20 \mathrm{~g}$ de solo seco, foram colocadas em frascos de vidro de $200 \mathrm{~cm}^{3}$. Uma delas foi fumigada em um dessecador revestido com papel-toalha umedecido junto com um pequeno béquer contendo $25 \mathrm{~mL}$ de clorofórmio $\left(\mathrm{CHCl}_{3}\right)$ livre de álcool e pérolas de vidro. $\mathrm{O}$ conjunto foi despressurizado com auxílio de uma bomba de vácuo por 5 minutos até o clorofórmio borbulhar, sendo então mantido fechado por 24 horas. Em seguida, o vapor residual de $\mathrm{CHCl}_{3}$ foi removido do solo através de repetidas despressurizações e retorno à pressão atmosférica. As subamostras fumigadas e não fumigadas (controle) foram transferidas para erlenmayer de $250 \mathrm{~cm}^{3}$ para a extração do carbono, adicionando-se $100 \mathrm{~mL}$ de $\mathrm{K}_{2} \mathrm{SO}_{4}$ 0,5 mol L $\mathrm{L}^{-1}$ e agitando-se o conjunto por 30 minutos. O extrato resultante foi filtrado em papel de filtro "Whatman n⿳⺈ 42".

O C orgânico foi determinado pela digestão de $8 \mathrm{~mL}$ do extrato com $2 \mathrm{~mL}$ de $\mathrm{K}_{2} \mathrm{Cr}_{2} \mathrm{O}_{7}$ 0,067 mol L $\mathrm{L}^{-1}$ e $15 \mathrm{~mL}$ de uma mistura de $\mathrm{H}_{2} \mathrm{SO}_{4}$ e $\mathrm{H}_{3} \mathrm{PO}_{4}$ concentrados na proporção de 2:1 (v/v). Após o aquecimento em banho-maria por 1 hora, adicionaram-se $10 \mathrm{~mL}$ de água deionizada e o excesso de dicromato foi determinado por titulação com $\mathrm{Fe}\left(\mathrm{NH}_{4}\right)_{2}\left(\mathrm{SO}_{4}\right)_{2} \cdot 6 \mathrm{H}_{2} \mathrm{O}$ (sulfato ferroso amoniacal) $0,33 \mathrm{~mol} \mathrm{~L}^{-1} \mathrm{em} \mathrm{H}_{2} \mathrm{SO}_{4} 0,4 \mathrm{~mol} \mathrm{~L}^{-1}$, usando-se fenolftaleína como indicador. A quantidade de dicromato consumido foi dada pela diferença entre o excesso titulado no extrato de solo e aquele que sobrou numa digestão em branco de $8 \mathrm{~mL}$ do extrator $\left(\mathrm{K}_{2} \mathrm{SO}_{4} 0,5 \mathrm{~mol} \mathrm{~L}^{-1}\right)$. A biomassa microbiana - $\mathrm{C}$ foi calculada pela seguinte equação:

Biomassa microbiana- $\mathrm{C}\left(\mathrm{mg} \mathrm{Kg}^{-1}\right.$ solo seco $)=\left(\mathrm{C}_{\mathrm{F}}-\mathrm{C}_{\mathrm{NF}}\right) / 0,33$

onde: $\mathrm{C}_{\mathrm{F}}=$ quantidade de carbono $\left(\mathrm{mg} \mathrm{kg}^{-1}\right.$ solo seco) na amostra fumigada $\mathrm{C}_{\mathrm{NF}}=$ quantidade de carbono $\left(\mathrm{mg} \mathrm{kg}^{-1}\right.$ solo seco) na amostra não fumigada 
0,33 = fator de correção $\left.k_{\mathrm{EC}}\right)$ que representa a eficiência de extração do carbono (Sparling \& West, 1988)

- $\quad$ - microbiano

O mesmo princípio foi empregado na determinação do $\mathrm{N}$ da biomassa microbiana, quantificado pelos compostos reativos a ninidrina (Joergensen \& Brookes, 1990).

Do mesmo extrato obtido para a quantificação da biomassa $C$, pipetou-se uma alíquota de 0,6 mL em tubo de ensaio de $20 \mathrm{~mL}$, ao qual acrescentour se 1,4 $\mathrm{mL}$ de ácido cítrico $\left(0,2 \mathrm{~mol} \mathrm{~L} \mathrm{~L}^{-1}, \mathrm{pH} 5\right)+1 \mathrm{~mL}$ de reagente ninidrina $(2 \mathrm{~g})+$ hydrindatina $(0,3 \mathrm{~g})$, ambos dissolvidos em dimetillsulfoxido (DMSO) $(75 \mathrm{~mL})$ + acetato de lítio $(25 \mathrm{~mL}, 4$ mol $\left.\mathrm{L}^{-1}, \mathrm{pH} 5,2\right)$. O tubo foi colocado em manho-maria a $100^{\circ} \mathrm{C}$ por $20 \mathrm{mim}$. Quando a temperatura da solução voltou a temperatura ambiente adicionaram-se $4 \mathrm{~mL}$ de etanol e fez-se a leitura da coloração do líquido em espectrofotômetro a $570 \mathrm{~nm}$ de comprimento de onda. Os resultados foram comparados com uma curva padrão construída com base no aminoácido leucina-L. A biomassa microbiana-N foi calculada pela seguinte equação:

Biomassa microbiana $-\mathrm{N}\left(\mathrm{mg} \mathrm{Kg}^{-1}\right.$ solo seco $)=\left(\mathrm{CRN}_{\mathrm{F}}-\mathrm{CRN}_{\mathrm{NF}}\right) \times 6,5$

onde: $\mathrm{CRN}_{\mathrm{F}}=$ quantidade de compostos reativos à ninidrina $\left(\mathrm{mg} \mathrm{kg}^{-1}\right.$ solo seco $)$ na amostra fumigada

$\mathrm{CRN}_{\mathrm{NF}}=$ quantidade de compostos reativos à ninidrina $\left(\mathrm{mg} \mathrm{kg}^{-1}\right.$ solo seco $)$ na amostra não fumigada

6,5 = fator de correlação que representa a eficiência de extração dos compostos reativos àninidrina (Sparling et al., 1993). 


\subsubsection{Forma de análises dos resultados}

Os resultados obtidos foram submetidos à análise de variância pelo teste $\mathrm{F}$, segundo o esquema fatorial $2 \times 2 \times 4$ ou $3 \times 2 \times 4$, considerando os dois tempos de adoção ou as três classes texturais, as seqüências de culturas e as profundidades como fator principal, secundário e terciário, respectivamente. Para tal, utilizou-se o procedimento GLM do programa de análise estatística SAS (SAS Institute, 1987). A comparação das médias foi realizada pelo teste Tukey a 5\%. Também foi realizada a análise de correlação linear simples de Pearson (Procedimento CORR do SAS) entre o $\mathrm{C}$ e o $\mathrm{N}$-microbiano e os teores de amônia e nitrato do solo.

\subsection{Resultados e discussão}

\subsubsection{Característica física e química das áreas estudadas}

Dentre as áreas há 12 anos sob SPD com diferentes texturas, a mais argilosa (PD12-TmuA) apresentou densidade 27\% menor na camada 0-20 cm que a PD12-TmeA e 25\% menor que a PD12-TA (Tabela 3). Esse efeito era esperado, uma vez que as partículas dos solos com textura fna apresentam maior espaço poroso total que os solos com textura mais grosseira, principalmente se o solo argiloso possuir alto teor de matéria orgânica. Em solos com texturas similares, o teor de matéria orgânica pode determinar a densidade (O’Sullivan, 1992; Arvisson, 1998), como foi observado na comparação das áreas PD12 e PD22-TA, onde a primeira é 9\% mais densa que a segunda.

A área PD12-TmuA apresentou os menores pHs nas camadas 0-2,5 e 2,5-5,0 cm ( $\mathrm{pH}(\mathrm{KCl})$ 4,4 e 4,2 respectivamente), característica que pode estar relacionada ao maior teor de argila (72\%), com suas cargas elétricas negativas na superfície. De um modo geral, a acidez do solo favorece os fungos em relação às bactérias, embora algumas 
bactérias autotróficas oxidantes de $\mathrm{S}$ e $\mathrm{Fe}$ tolerem $\mathrm{pH}$ menor que 1,0 como bem mencionado por Moreira e Siqueira (2002). Observou-se um gradiente decrescente do $\mathrm{pH}_{(\mathrm{KCl})}$ das camadas superficiais do solo para as mais profundas, cuja amplitude, no entanto, não ultrapassou 0.9. A menor variação foi observada na área PD12-TmuA. O Delta $\mathrm{pH}\left(\mathrm{KCl}-\mathrm{H}_{2} \mathrm{O}\right)$ das áreas foram negativos; com significado que há predominância de cargas negativas no solo. Os resultados Bayer \& Bertol (1999) em condições de solo subtropicais e em solos de cargas variáveis, mostraram que o retorno de resíduos culturais com 40 a $50 \%$ de $\mathrm{C}$, associado ao não revolvimento do solo aumenta a MOS e a carga negativa líquida. Infelizmente, não foram encontrados na literatura estudos sobre a relação entre o Delta $\mathrm{pH}$ e as cargas variáveis com a BMS em solos subtropicais e tropicais, portanto é uma lacuna que precisa ser preenchida com informações desta natureza.

De maneira geral as áreas apresentaram se fértil, e proporcional aos teores de argila e MOS. Com o seguinte decréscimo de fertilidade: PD12 - TmuA > PD22 - TA > PD12 - TA > PD12 - TmeA. Os maiores teores de bases tocáveis, P, K eV\% foram encontrados nas camadas $0-2,5$ e 2,5-5,0cm. Estudos mostram que a fertilidade química do solo beneficia os microrganismos devido a maior disponibilidade de nutrientes no solo e menor competitividade como as plantas pelo os mesmos (Sneh Goyal, et al., 1992, Dalal, 1998). Entretanto, como é sabido esse fator não é o preponderante para o desenvolvimento dos microrganismos.

A textura muito argilosa também favoreceu os teores de $\mathrm{C}$ e $\mathrm{N}$ total da camada 0-20cm, que foram 100\% maior que na área PD12-TA e respectivamente 2,6 e 2,3 vezes maior que na área PD12-TmeA (Quadro 2). Da mesma forma, a distribuição no perfil 
apresentou, mais uma vez, a menor variabilidade, com um declínio de somente 28 e $34 \%$ nos teores de $\mathrm{C}$ e $\mathrm{N}$ total. $\mathrm{O}$ tempo de adoção do SPD proporcionou aumento de 1,4 e 1,3 vezes o $\mathrm{C}$ e $\mathrm{N}$ total na área PD22-TA em relação à área PD12-TA na camada $0-20 \mathrm{~cm}$. O gradiente decrescente desses elementos no perfil do solo foi semelhante nas duas áreas. Os resultados acima estão de acordo com os obtidos por outros autores (Staley, et al. 1988; Cambardella \& Elliot, 1992; Sá, J. 2001) no que diz respeito à textura do solo e o do tempo de adoção do SPD.

Tabela 6. Teores carbono e nitrogênio total nas áreas de estudo

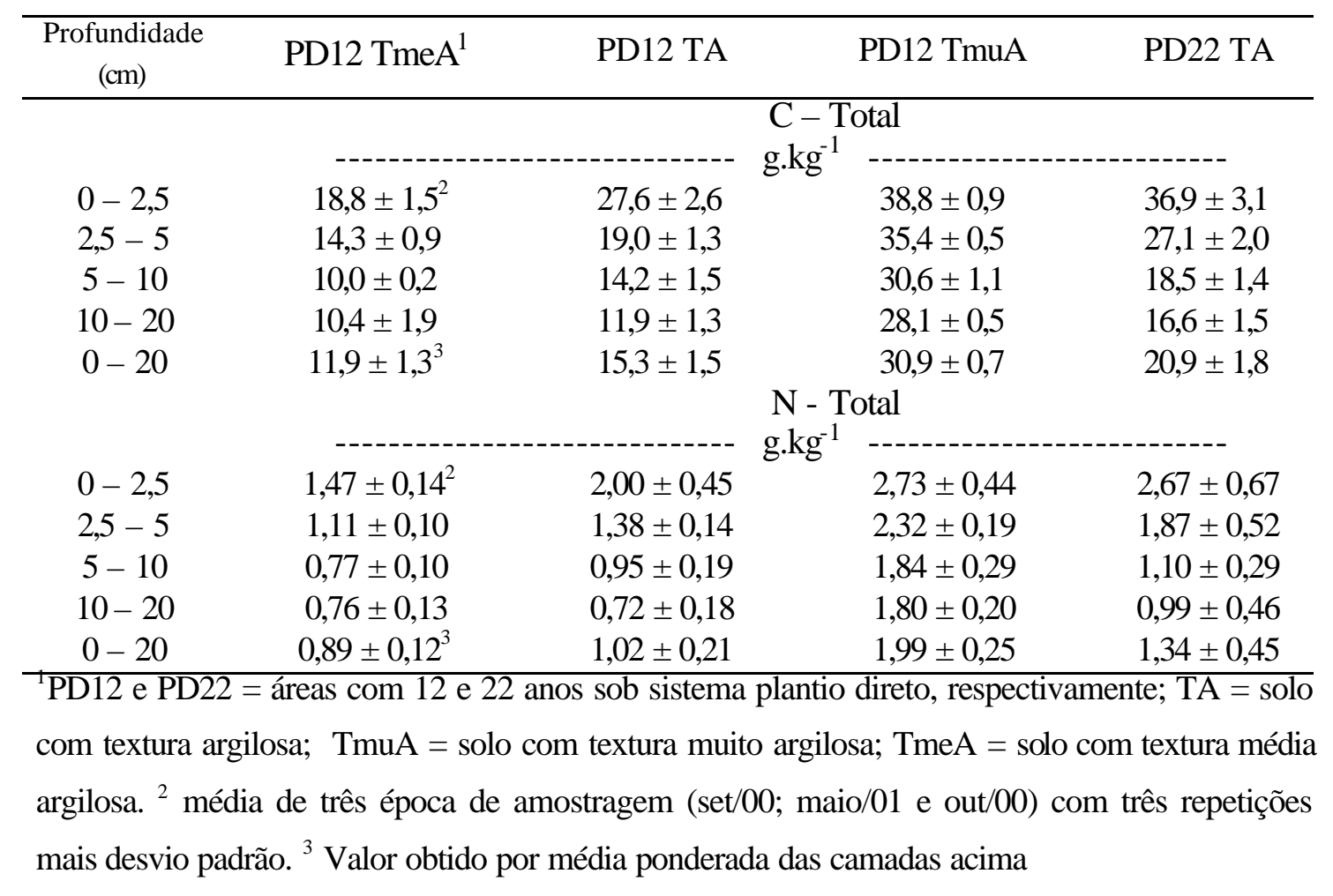




\subsubsection{Variação do C e N microbianos em função do tempo de adoção do SPD}

$\mathrm{O}$ efeito do tempo de adoção do SPD sobre o $\mathrm{C}$ e $\mathrm{N}$-microbianos não foi significativo na análise de variância pelo teste $\mathrm{F}$ para alguns meses na sequiência de culturas, tempo de adoção do SPD e para a interação sequiência de culturas e tempo de adoção (Tabela 7).

No inicio do experimento (set/00) foram encontrados cerca de $320 \mathrm{~kg} \mathrm{C}_{\mathrm{mic}} \mathrm{ha}^{-1} \mathrm{a}$ mais na área PD22-TA do que na área PD12-TA, na camada 0-20 cm. Durante o período analisado a área há mais tempo sob SPD (PD22) manteve a tendência a permanecer com a biomassa microbiana maior (Figura 6b), exceto nas épocas após o plantio do milho e da soja (nov/00) e do trigo (jun/01), provavelmente devido ao efeito da adubação de base e de cobertura que foram feitas cerca de 20 dias antes das amostragens do solo. É sabido que os fertilizantes minerais provocam alterações na BMS, em geral aumento da mesma (Marumoto, 1984; Sneh Goyal, et al., 1992). Aliado ao efeito dos fertilizantes, as chuvas (nov/00 e maio/01) e temperaturas elevadas (nov/00) (Figura 2) podem ter contribuído com o desvio da tendência. Carvalho (1997) verificou em Latossolo Vermelho na região de Carambeí - PR que as condições climáticas entre elas precipitações e temperaturas influenciaram o C-microbiano e a atividade microbiana no solo. 
Tabela 7. C e N-microbianos em função do tempo de adoção do sistema plantio direto (12 e 22 anos) em solo de textura argilosa (TA) sob duas seqüências de culturas (A e B)

\begin{tabular}{|c|c|c|c|c|c|c|c|c|c|c|c|c|}
\hline \multirow[b]{2}{*}{ Prof. } & \multicolumn{3}{|c|}{ PD12-TA } & \multicolumn{3}{|c|}{ PD22-TA } & \multicolumn{3}{|c|}{ PD12-TA } & \multicolumn{3}{|c|}{ PD22-TA } \\
\hline & $\mathrm{A}^{1}$ & $\mathrm{~B}^{1}$ & $\mathrm{~m}^{2}$ & $\mathrm{~A}$ & $\mathrm{~B}$ & $\mathrm{~m}$ & $\mathrm{~A}$ & $\mathrm{~B}$ & $\mathrm{~m}$ & $\mathrm{~A}$ & $\mathrm{~B}$ & $\mathrm{~m}$ \\
\hline $\mathrm{cm}$ & \multirow{2}{*}{\multicolumn{12}{|c|}{ 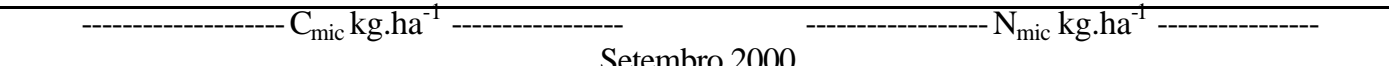 }} \\
\hline & & & & & \multicolumn{6}{|c|}{ Setembro 2000} & & \\
\hline $0-2,5$ & - & - & $136 \mathrm{~A}$ & - & - & $127 \mathrm{~A}$ & - & - & $48 \mathrm{~A}$ & - & - & $38 \mathrm{~A}$ \\
\hline $2,5-5$ & - & - & $90 \mathrm{~B}$ & & - & $189 \mathrm{~A}$ & - & - & $33 \mathrm{~A}$ & - & - & $37 \mathrm{~A}$ \\
\hline $5-10$ & - & - & $159 \mathrm{~B}$ & - & - & $240 \mathrm{~A}$ & - & - & $45 \mathrm{~A}$ & - & - & $35 \mathrm{~A}$ \\
\hline $10-20$ & - & - & $214 \mathrm{~B}$ & - & - & $\begin{array}{r}364 \mathrm{~A} \\
\text { C.V. } 29 \%\end{array}$ & - & - & $53 \mathrm{~A}$ & - & - & $\begin{array}{c}31 \mathrm{~A} \\
\mathrm{~V} .35 \%\end{array}$ \\
\hline & \multicolumn{12}{|c|}{ Outubro 2000} \\
\hline $0-2,5$ & 128 & $\mathrm{nd}^{3}$ & $128 \mathrm{~A}$ & 240 & nd & $240 \mathrm{~A}$ & 41 & nd & $41 \mathrm{~A}$ & 45 & nd & $45 \mathrm{~A}$ \\
\hline $2,5-5$ & 128 & nd & $128 \mathrm{~A}$ & 228 & nd & $228 \mathrm{~A}$ & 18 & nd & $18 \mathrm{~B}$ & 34 & nd & $34 \mathrm{~A}$ \\
\hline $5-10$ & 188 & nd & $188 \mathrm{~B}$ & 369 & nd & $369 \mathrm{~A}$ & 17 & nd & $17 \mathrm{~B}$ & 33 & nd & $33 \mathrm{~A}$ \\
\hline $10-20$ & 290 & nd & $290 \mathrm{~B}$ & 620 & nd & $\begin{array}{r}620 \mathrm{~A} \\
\text { C.V. } 40 \%\end{array}$ & 15 & nd & $15 \mathrm{~B}$ & 47 & nd & $\begin{array}{c}47 \mathrm{~A} \\
\text { V. } 32 \%\end{array}$ \\
\hline \multicolumn{13}{|c|}{ Novembro 2000} \\
\hline $0-2,5$ & $152 a^{4}$ & $168 \mathrm{a}$ & $160^{\mathrm{ns}}$ & 184 & 158 & 171 & $31^{\mathrm{ns}}$ & 46 & $39 \mathrm{~A}$ & $34^{\mathrm{ns}}$ & 50 & $42 \mathrm{~A}$ \\
\hline $2,5-5$ & $150 \mathrm{a}$ & $122 \mathrm{a}$ & 136 & 178 & 134 & 156 & 22 & 30 & $26 \mathrm{~A}$ & 28 & 37 & $33 \mathrm{~A}$ \\
\hline $5-10$ & $289 \mathrm{a}$ & $195 b$ & 242 & 257 & 194 & 226 & 35 & 31 & $33 \mathrm{~A}$ & 33 & 34 & $34 \mathrm{~A}$ \\
\hline $10-20$ & $\begin{array}{c}518 \mathrm{a} \\
\text { C.V. }\end{array}$ & $\begin{array}{l}351 \mathrm{~b} \\
1 \%\end{array}$ & 435 & 476 & 406 & 441 & $\begin{array}{l}30 \\
\mathrm{C}\end{array}$ & $\begin{array}{r}45 \\
0 \%\end{array}$ & $37 \mathrm{~B}$ & 66 & 70 & $\begin{array}{c}68 \mathrm{~A} \\
\text { V. } 36 \%\end{array}$ \\
\hline \multicolumn{13}{|c|}{ Fevereiro 2001} \\
\hline $0-2,5$ & $96^{\mathrm{ns}}$ & 78 & $87 \mathrm{~A}$ & $129^{\mathrm{ns}}$ & 121 & $125 \mathrm{~A}$ & $17^{\mathrm{ns}}$ & 18 & $18^{\mathrm{ns}}$ & $33^{\mathrm{ns}}$ & 35 & 34 \\
\hline $2,5-5$ & 89 & 88 & $89 \mathrm{~B}$ & 199 & 169 & $184 \mathrm{~A}$ & 16 & 16 & 16 & 34 & 34 & 34 \\
\hline $5-10$ & 122 & 106 & $114 \mathrm{~B}$ & 304 & 230 & $267 \mathrm{~A}$ & 21 & 23 & 22 & 42 & 31 & 36 \\
\hline $10-20$ & 220 & 148 & $184 \mathrm{~B}$ & 382 & 395 & $\begin{array}{r}389 \mathrm{~A} \\
\text { C.V. } 35 \%\end{array}$ & 22 & 28 & 25 & 57 & 63 & $\begin{array}{c}60 \\
\text { V. } 48 \%\end{array}$ \\
\hline & & \multicolumn{11}{|c|}{ Maio 2001} \\
\hline $0-2,5$ & $120^{\mathrm{ns}}$ & 132 & $126 \mathrm{~A}$ & $139^{\mathrm{ns}}$ & 156 & $147 \mathrm{~A}$ & $36^{\mathrm{ns}}$ & 41 & $38^{\mathrm{ns}}$ & $31^{\mathrm{ns}}$ & 30 & 31 \\
\hline $2,5-5$ & 83 & 116 & $100 \mathrm{~A}$ & 117 & 158 & $137 \mathrm{~A}$ & 33 & 30 & 32 & 25 & 25 & 25 \\
\hline $5-10$ & 137 & 128 & $132 \mathrm{~B}$ & 215 & 214 & $214 \mathrm{~A}$ & 37 & 40 & 38 & 17 & 31 & 24 \\
\hline $10-20$ & 235 & 226 & $231 \mathrm{~B}$ & 487 & 486 & $\begin{array}{c}487 \mathrm{~A} \\
\text { C.V. } 42 \%\end{array}$ & 81 & 58 & 70 & 31 & 38 & $\begin{array}{c}34 \\
\text { V. } 52 \%\end{array}$ \\
\hline \multicolumn{13}{|c|}{$\begin{array}{l}\text { C.V. } 42 \% \\
\text { Junho } 2001\end{array}$} \\
\hline $0-2,5$ & $210^{\mathrm{ns}}$ & 216 & $213 \mathrm{~A}$ & $192^{\mathrm{ns}}$ & 157 & $175 \mathrm{~A}$ & $38^{\mathrm{ns}}$ & 43 & $41^{\mathrm{ns}}$ & $37^{\mathrm{ns}}$ & 35 & 36 \\
\hline $2,5-5$ & 160 & 185 & $173 \mathrm{~A}$ & 147 & 129 & $134 \mathrm{~A}$ & 28 & 32 & 30 & 35 & 34 & 35 \\
\hline $5-10$ & 236 & 291 & $264 \mathrm{~A}$ & 215 & 194 & $205 \mathrm{~A}$ & 16 & 26 & 21 & 32 & 29 & 30 \\
\hline $10-20$ & 465 & 467 & $466 \mathrm{~A}$ & 349 & 219 & $284 \mathrm{~B}$ & 38 & 43 & 40 & 63 & 43 & 53 \\
\hline
\end{tabular}

${ }^{\mathrm{T}}$ Sequências de culturas: $\mathrm{A}=$ milho/trigo/soja e $\mathrm{B}=$ soja/trigo/soja; ${ }^{2} \mathrm{~m}=$ média das seqüências de culturas A e B (n=10); ${ }^{3}$ nd = não determinado; ${ }^{4}$ Médias seguidas de mesma letra, minúscula para sucessões e maiúscula para tempo de adoção na mesma linha, não diferem estatisticamente entre si pelo teste de Tukey a 5\%; $\mathrm{ns}=$ análise de variância não significativa pelo teste $\mathrm{F}$ a 5\% 
Tabela 7. C e N-microbianos em função do tempo de adoção do sistema plantio direto $(12$ e 22 anos) em solo de textura argilosa (TA) sob duas sequiências de culturas (A e B)

\begin{tabular}{|c|c|c|c|c|c|c|c|c|c|c|c|c|}
\hline \multirow[b]{2}{*}{ Prof. } & \multicolumn{3}{|c|}{ PD12-TA } & \multicolumn{3}{|c|}{ PD22-TA } & \multicolumn{3}{|c|}{ PD12-TA } & \multicolumn{3}{|c|}{ PD22-TA } \\
\hline & $\mathrm{A}^{1}$ & $\mathrm{~B}^{1}$ & $\mathrm{~m}^{2}$ & A & B & $\mathrm{m}$ & $\mathrm{A}$ & B & $\mathrm{m}$ & A & B & $\mathrm{m}$ \\
\hline $\mathrm{cm}$ & \multicolumn{12}{|c|}{ - $\mathrm{C}_{\mathrm{mic}}$ kg.ha ${ }^{-1}$-- } \\
\hline & \multicolumn{12}{|c|}{ Agosto 2001} \\
\hline $0-2,5$ & $171^{\mathrm{ns}}$ & 165 & $168^{\mathrm{ns}}$ & $198^{\mathrm{ns}}$ & 254 & 226 & $30 \mathrm{a}$ & $36 \mathrm{a}$ & $33^{\text {ns }}$ & $55^{\mathrm{ns}}$ & 50 & 53 \\
\hline $2,5-5$ & 134 & 139 & 137 & 176 & 159 & 168 & $14 \mathrm{a}$ & $25 \mathrm{a}$ & 19 & 37 & 36 & 37 \\
\hline $5-10$ & 151 & 238 & 197 & 281 & 196 & 239 & $16 \mathrm{a}$ & $17 \mathrm{a}$ & 17 & 36 & 32 & 34 \\
\hline $10-20$ & 301 & 359 & 330 & 359 & 328 & 343 & $55 \mathrm{a}$ & $25 \mathrm{~b}$ & 40 & 43 & 41 & 42 \\
\hline & & & & & & C.V. $37 \%$ & & $52 \%$ & & & & \\
\hline & \multicolumn{12}{|c|}{ Outubro 2001} \\
\hline $0-2,5$ & 150 & 129 & $139 \mathrm{~B}$ & 202 & 285 & $244 \mathrm{~A}$ & $30^{\mathrm{ns}}$ & 37 & $34^{\mathrm{ns}}$ & $50^{\mathrm{ns}}$ & 42 & 46 \\
\hline $2,5-5$ & 121 & 120 & $120 \mathrm{~B}$ & 226 & 274 & $250 \mathrm{~A}$ & 22 & 29 & 25 & 46 & 36 & 41 \\
\hline $5-10$ & 209 & 186 & 197 B & 402 & 439 & $421 \mathrm{~A}$ & 18 & 23 & 21 & 44 & 32 & 38 \\
\hline $10-20$ & 355 & 465 & $410 \mathrm{~B}$ & 577 & 841 & $709 \mathrm{~A}$ & 31 & 31 & 31 & 43 & 53 & 48 \\
\hline & \multirow{2}{*}{\multicolumn{9}{|c|}{ C.V. 33\% }} & \multirow{2}{*}{\multicolumn{3}{|c|}{ C.V. $27 \%$}} \\
\hline & & & & & & & & & & & & \\
\hline $0-2,5$ & $71^{\mathrm{ns}}$ & 88 & $79 \mathrm{~A}$ & $102^{\mathrm{ns}}$ & 80 & $91 \mathrm{~A}$ & $24^{\mathrm{ns}}$ & 25 & $25^{\mathrm{ns}}$ & $33^{\mathrm{ns}}$ & 36 & 34 \\
\hline $2,5-5$ & 73 & 65 & $69 \mathrm{~A}$ & 83 & 66 & $75 \mathrm{~A}$ & 20 & 23 & 22 & 28 & 28 & 28 \\
\hline $5-10$ & 73 & 114 & $94 \mathrm{~A}$ & 101 & 88 & $95 \mathrm{~A}$ & 20 & 21 & 21 & 33 & 32 & 33 \\
\hline $10-20$ & 120 & 126 & $123 \mathrm{~B}$ & 263 & 203 & $\begin{array}{l}233 \mathrm{~A} \\
\text { C.V. } 50 \%\end{array}$ & 25 & 28 & 26 & 47 & 41 & $\begin{array}{c}44 \\
\text { C.V. } 28 \%\end{array}$ \\
\hline
\end{tabular}

${ }^{1}$ Sequências de culturas: $\mathrm{A}=$ milho/trigo/soja e $\mathrm{B}=$ soja/trigo/soja; ${ }^{2} \mathrm{~m}=$ média das sequiências de culturas A e B (n=10); ${ }^{3}$ nd = não determinado; ${ }^{4}$ Médias seguidas de mesma letra, minúscula para sucessões e maiúscula para tempo de adoção na mesma linha, não diferem estatisticamente entre si pelo teste de Tukey a 5\%; $\mathrm{ns}=$ análise de variância não significativa pelo teste $\mathrm{F}$ a 5\%

O efeito da sequiência de culturas nas quantidades de BMS não pode ser verificado (Tabela 7) na maioria das épocas estudadas na maioria das épocas de amostragem, devido a interferência de efeitos não controláveis que impossibilitaram a interpretação dos dados (análise de variância não significativa a $5 \%$ pelo teste F). Entretanto os valores das médias C e N-microbiano na sua grande maioria apresentaram-se próximas nas duas áreas. Provavelmente devido a uma adaptação da composição da comunidade microbiana à influência do milho, soja, trigo, cultivados há mais de dez anos nessas áreas. Eventuais alterações também podem não ter sido detectadas pelos métodos quantitativos de massa empregados para determinar a BMS. 
a)

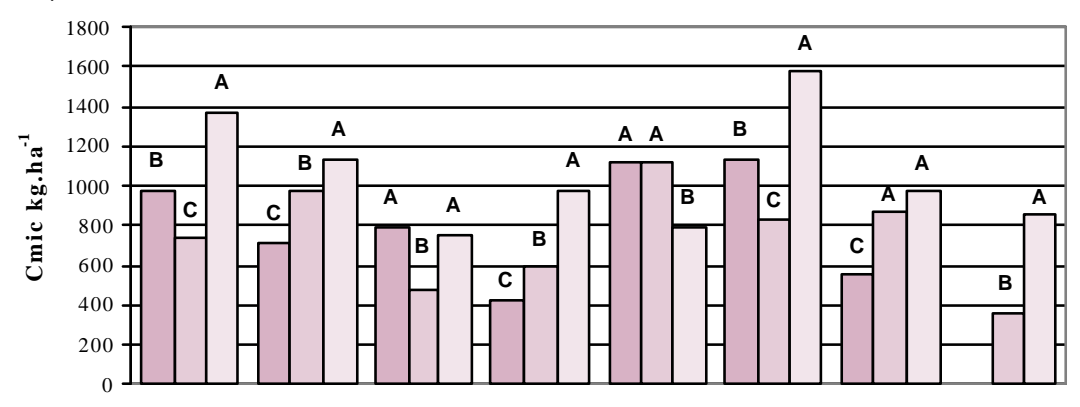

c)

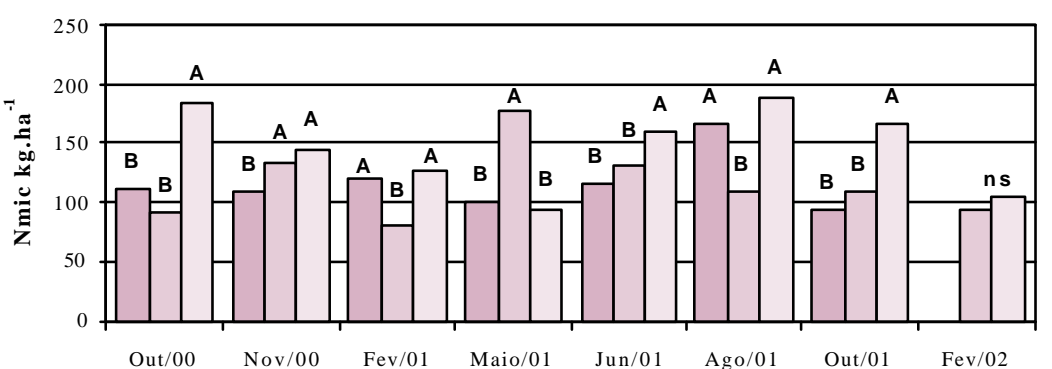

$\square \mathrm{PD} 12$ - TmeA $\square \mathrm{PD} 12$ - TA $\square \mathrm{PD} 12-\mathrm{TmuA}$

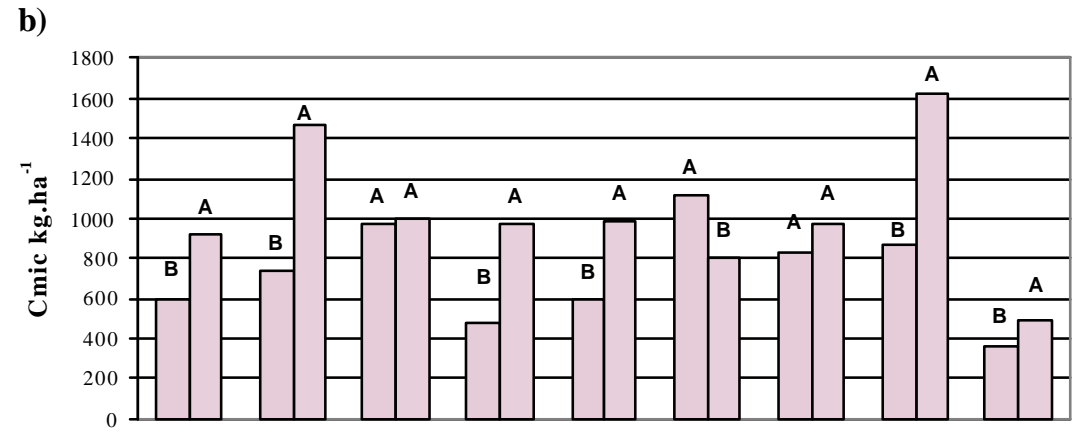

d)

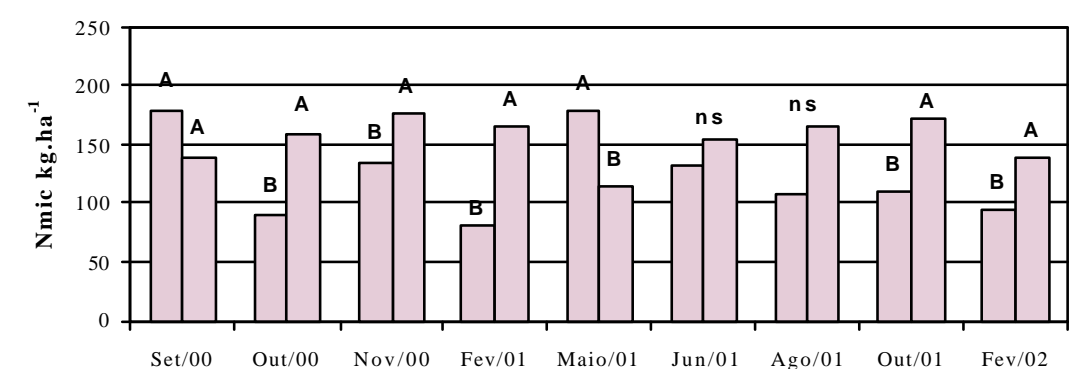

$\square \mathrm{PD} 12$ - TA $\square \mathrm{PD} 22-\mathrm{TA}$

Figura 6 - Teores de C e N em solos de diferentes classes texturais (a e c) sob 12 (PD12) e 22 (PD22) anos de adoção de sistema plantio direto (b e c) na camada $0-20 \mathrm{~cm} . \mathrm{TA}=$ solo com textura argilosa; $\mathrm{TmuA}=$ solo com textura muito argilosa; Tme A = solo com textura média argilosa. Médias seguidas de mesma letra não diferem estatisticamente entre si pelo teste Tukey a 5\%.ns $=$ Análise de variância não significativa pelo teste $\mathrm{F}$ a $5 \%$ 
Métodos qualitativos talvez fossem mais sensíveis às mudanças em curto prazo na comunidade microbiana. Outros autores também não obtiveram diferenças significativas de C-microbiano (Cattelan et al., 1997; Balota et al., 1998) e Nmicrobiano (Omay et. Al.,1997; Balota et al.; 1998; Souza \& Melo, 2000) em solo sob a rotação de cultura no SPD. Souza \& Melo (2000) analisaram o efeito da rotação de culturas e verificaram que os resíduos da cultura anterior influenciaram mais do que a quantidade de $\mathrm{N}$-microbiano no $\mathrm{N}$ potencialmente mineralizável. No trabalho de Omay et al. (1997) o C-microbiano foi influenciado pela sequiência milho-milho em solo franco arenoso, mas não pela seqüência milho-soja, e ambas as sequiências não influenciaram o N-microbiano. Os autores sugerem uma determinada cultura da seqüência pode ter mais efeito sobre a BMS que a rotação de culturas como um todo.

Após o plantio de milho e da soja (nov/00), a quantidade de C-microbiano nas camadas abaixo de $5 \mathrm{~cm}$ diferiu entre as sequiências A e B da área PD12-TA. A causa provável foi à presença das raízes do milho em profundidade, enquanto a soja apresentava ainda pouco crescimento radicular aos dez dias pós-emergência. $\mathrm{O}$ mesmo não foi observado na área PD22-TA, onde as condições favoráveis à comunidade microbiana, proporcionadas pelo tempo de adoção do SPD, tais como água, temperatura, substrato facilmente assimilável diluíram esse efeito. Alterações na estrutura do solo também podem ocorrer com o tempo de adoção do SPD (Beare et al., 1994; Six, et al., 1999; Six, et al., 2002) e com o aumento de C nas camadas mais profundas (Sá et al., 2001). Diversos trabalhos relatam que o C-microbiano está estreitamente relacionado com o C do solo, e mais ainda com o C-orgânico facilmente assimilável pela BMS (Lynch \& Parting, 1980; Powlson et al.,1987; Sparling, 1992; Witter, 1996). 
Nas épocas de ausência de plantas (set/00 e maio/01) e presença somente dos resíduos da cultura anterior, a área PD22-TA apresentou menores quantidades de $\mathrm{N}$ microbiano que a PD12-TA na camada de 0-20 cm (Figura 6d), embora em setembro a diferença não tenha sido estatisticamente significativa. Nas amostragens seguintes (out/00 no milho e na soja; e jun/01 e ago/01 no trigo), quando ocorreu entrada de fertilizantes e havia presença de um sistema radicular ativo no solo, a área PD22-TA apresentou $42 \mathrm{~kg} \mathrm{~N}_{\text {mic }} \mathrm{ha}^{-1}$ mais do que a área PD12-TA na fase vegetativa do milho (out/00) e 22 e $54 \mathrm{~kg} \mathrm{~N}_{\text {mic }} \mathrm{ha}^{-1}$ na fase vegetativa do trigo. Na média geral do período estudado, a superioridade do sistema mais antigo ficou em $30,8 \mathrm{~kg} \mathrm{~N}_{\text {mic }} \mathrm{ha}^{-1}$. Esses resultados corroboram com os encontrados por Sá, J. (2001), que observou um aumento na camada $0-5 \mathrm{~cm}$ de $63,8 \mathrm{~kg} \mathrm{~N}_{\text {mic }}$ ha $^{-1}$ para $75,5 \mathrm{~kg} \mathrm{~N}_{\text {mic }}$ ha $^{-1}$ em áreas há 10 e 20 anos sob SPD. Segundo Chen \& Stark (2000), quando se tem alta disponibilidade de C e ampla relação $\mathrm{C} / \mathrm{N}$ no substrato, aliado a fatores climáticos propícios à atividade microbiana, como nesses períodos, ocorre aumento de microsítios de imobilização de $\mathrm{N}$. Nesse sentido, Sá (1996) propôs a antecipação da adubação nitrogenada do milho quando este é cultivado sobre os resíduos de gramínea com alta relação C/N. O objetivo seria evitar os aspectos negativos da imobilização de $\mathrm{N}$ pela BMS. Além dos fatores climáticos e edáficos que podem influenciar a estratégia de fertilização devemos também considerar o tempo de adoção do SPD que influência a quantidade de $\mathrm{N}$ imobilizado no solo na fase inicial do desenvolvimento da cultura, como demonstrado pelos resultados apresentados na Figura 6d.

Mesmo com os valores maior $\mathrm{N}$-microbiano, o PD22-TA ha ${ }^{-1}$ apresentou menor amplitude de variação do que na PD12-TA (87 contra $112 \mathrm{~kg} \mathrm{~N} \mathrm{~N}_{\text {mic }}$ ha $^{-1}$ ). Esse 
resultado sugere que o tempo de adoção do SPD contribuiu com a constância de Nimobilizado no solo na forma microbiana. Esse fato pode ser decorrente de uma cadeia trófica mais complexa, o que levaria maior estabilidade na ciclagem do N. De acordo com Moore \& de Ruiter (1991), o fluxo de N através dos organismos predadores de bactérias e fungos é maior em sistemas conservacionista do que no sistema convencional de cultivo. Nesse mesmo sentido, Lundquist et al. (1999) verificaram em três solos da Califómia - EUA com diferentes tipos de manejo e praticas culturais, que após a incorporação de resíduos vegetais ao solo o número de nematóides bacterófagos e fungífagos aumentou da primeira para a segunda semana.

\subsubsection{C e N microbiano em solos de diferentes texturas}

O efeito da textura do solo sobre o $\mathrm{C}$ e $\mathrm{N}$-microbianos não foi significativo na análise de variância pelo teste $F$ para alguns meses na sequiência das culturas e a na interação entre sequiência das culturas e textura (Tabela 8)

Quinze dias após o plantio (out/00) e 3 dias após a adubação nitrogenada do milho, a área PD12-TmuA apresentou 86 e 103\% mais C e N-microbiano do que a área PD12-TA e 39 e 66\% mais do que a PD12-TmeA na camada 0-20 cm (Figura 6a). A área PD12-TA (733 kg C $\mathrm{mic}_{\text {ic }} \mathrm{ha}^{-1}$ e $91 \mathrm{~kg} \mathrm{~N}_{\text {mic }} \mathrm{ha}^{-1}$ ) não apresentou maior quantidade de C e N-microbianos que a PD12-TmeA (981 kg Cmic ha ${ }^{-1}$ e $111 \mathrm{~kg} \mathrm{~N}_{\text {mic }} \mathrm{ha}^{-1}$ ) como se poderia esperar por ter maior teor de argila e de matéria orgânica. 
Tabela 8. Efeito da textura do solo no $\mathrm{C}$ e N-microbianos nas diferentes épocas em áreas há 12 anos sob sistema plantio direto em duas seqüências de culturas

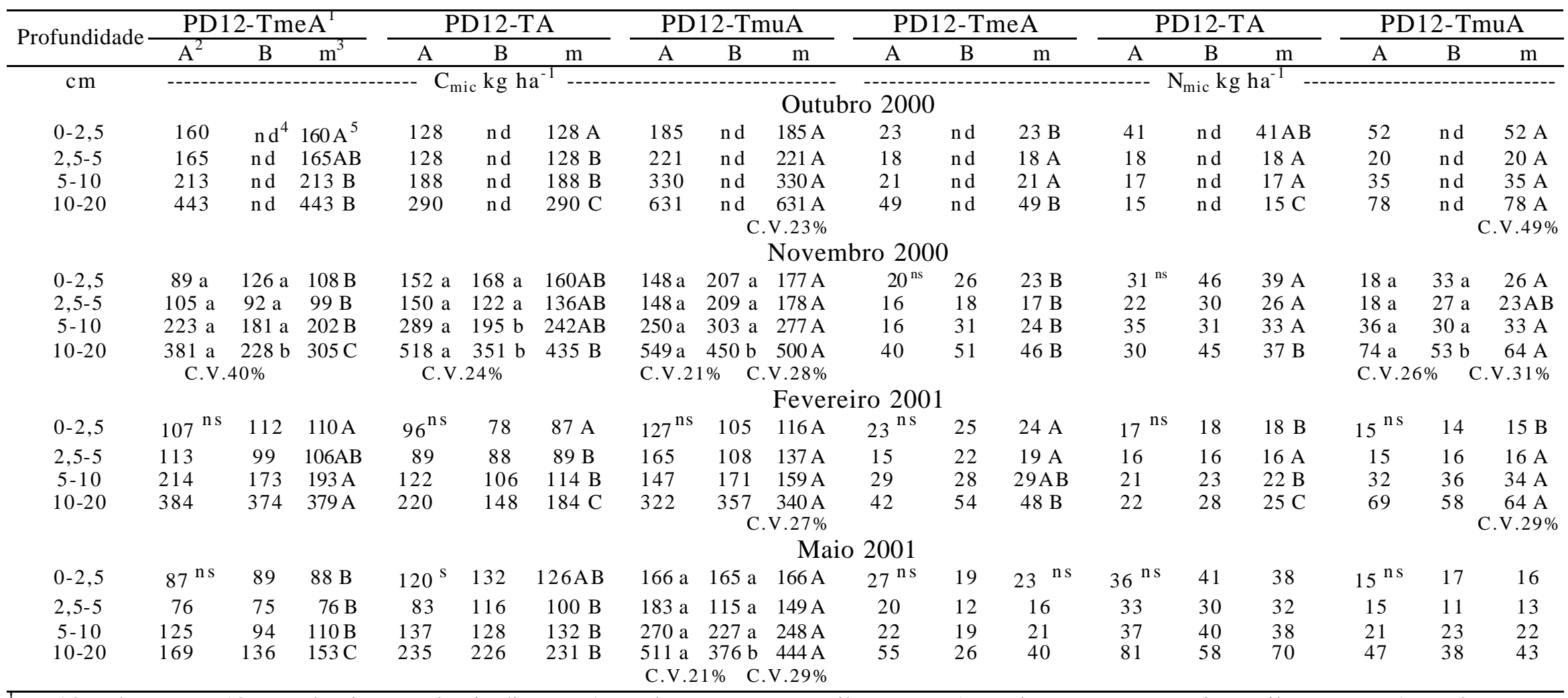

PD12 = áreas com 12 anos de sistema plantio direto; $\mathrm{TA}=$ solo com textura argilosa; TmuA = solo com textura muito argilosa e; Tme $\mathrm{A}=$ solo com textura média argilosa. ${ }^{2} \mathrm{~A}=$ sequiência de cultura Aveia-preta $/ \mathrm{milho} /$ trigo/soja e $\mathrm{B}=$ Aveia-preta/soja/trigo/soja; ${ }^{3} \mathrm{~m}=\mathrm{media}$ da seqüência de cultura $\mathrm{A}$ e B; ${ }^{4}$ nd = Não determinado ${ }^{5}$ Médias seguidas de mesma letra, minúscula para sucessões e maiúscula para tempo de adoção e classe textural na mesma linha, não diferem estatisticamente entre si pelo teste de Tukey a 5\%. ns = análise de variância não significativa pelo teste $\mathrm{F}$ a $5 \%$ 
Tabela 8. Efeito da textura do solo no $\mathrm{C}$ e $\mathrm{N}$-microbianos nas diferentes épocas em áreas há 12 anos sob sistema plantio direto em duas seqüiências de culturas

\begin{tabular}{|c|c|c|c|c|c|c|c|c|c|c|c|c|c|c|c|c|c|c|}
\hline \multirow{2}{*}{ Profundidade } & \multicolumn{3}{|c|}{$\mathrm{PD} 12-\mathrm{TmeA}^{1}$} & \multicolumn{3}{|c|}{ PD12-TA } & \multicolumn{3}{|c|}{ PD12-TmuA } & \multicolumn{3}{|c|}{ PD12-TmeA } & \multicolumn{3}{|c|}{ PD12-TA } & \multicolumn{3}{|c|}{ PD12-TmuA } \\
\hline & $\mathrm{A}^{2}$ & $\mathrm{~B}$ & $\mathrm{~m}^{3}$ & $\mathrm{~A}$ & $\mathrm{~B}$ & $\mathrm{~m}$ & $\mathrm{~A}$ & $\mathrm{~B}$ & $\mathrm{~m}$ & $\mathrm{~A}$ & $\mathrm{~B}$ & $\mathrm{~m}$ & $\mathrm{~A}$ & $\mathrm{~B}$ & $\mathrm{~m}$ & $\mathrm{~A}$ & $\mathrm{~B}$ & $\mathrm{~m}$ \\
\hline $\mathrm{cm}$ & ----- & & & $\cdots C$ & mic $\mathrm{kg}$ & $1 a^{-1}-$ & 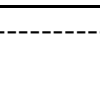 & ---- & Junl & 2001 & 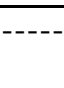 & & \multicolumn{3}{|c|}{$\mathrm{N}_{\mathrm{mic}} \mathrm{kg} \mathrm{ha}^{-1}$} & - & 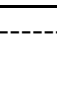 & --- \\
\hline $0-2,5$ & $163 \mathrm{a}$ & $163 \mathrm{a}$ & $163^{\mathrm{ns}}$ & $210^{\mathrm{ns}}$ & 216 & 213 & $108^{\mathrm{ns}}$ & 141 & 125 & $28^{\mathrm{ns}}$ & 31 & $30 \mathrm{~B}$ & $38^{\mathrm{ns}}$ & 43 & $41 \mathrm{~A}$ & $21^{\mathrm{ns}}$ & 24 & $23 \mathrm{~B}$ \\
\hline $2,5-5$ & $188 \mathrm{a}$ & $167 \mathrm{a}$ & 177 & 160 & 185 & 173 & 114 & 140 & 127 & 23 & 18 & $20 \mathrm{~A}$ & 28 & 32 & $30 \mathrm{~A}$ & 20 & 23 & $21 \mathrm{~A}$ \\
\hline $5-10$ & $284 \mathrm{a}$ & $268 \mathrm{a}$ & 276 & 236 & 291 & 264 & 181 & 215 & 198 & 29 & 22 & $26 \mathrm{~B}$ & 16 & 26 & $21 \mathrm{~B}$ & 39 & 42 & $41 \mathrm{~A}$ \\
\hline $10-20$ & $\begin{array}{l}578 \mathrm{a} \\
\text { C.V.2 }\end{array}$ & $\begin{array}{l}417 \mathrm{~b} \\
0 \%\end{array}$ & 497 & 465 & 467 & 466 & 358 & 338 & 348 & 32 & 48 & $40 \mathrm{~B}$ & 38 & 43 & $40 \mathrm{~B}$ & 79 & \multicolumn{2}{|c|}{ C.V. $31 \%$} \\
\hline $0-2,5$ & $210^{\mathrm{ns}}$ & 212 & $211 \mathrm{AB}$ & $171^{\mathrm{ns}}$ & 165 & $168 \mathrm{~B}^{5}$ & $301^{\mathrm{ns}}$ & 259 & $280 \mathrm{~A}$ & $42^{\mathrm{ns}}$ & 51 & $46^{\mathrm{ns}}$ & $30 \mathrm{a}$ & $36 \mathrm{a}$ & 33 & $42^{\mathrm{ns}}$ & 49 & 45 \\
\hline $2,5-5$ & 142 & 174 & $158 \mathrm{AB}$ & 134 & 139 & $136 \mathrm{~B}$ & 254 & 215 & $234 \mathrm{~A}$ & 28 & 35 & 32 & $14 \mathrm{a}$ & $25 \mathrm{a}$ & 19 & 29 & 39 & 34 \\
\hline $5-10$ & 315 & 269 & 292 B & 151 & 238 & $195 \mathrm{C}$ & 430 & 335 & $383 \mathrm{~A}$ & 41 & 26 & 34 & $16 \mathrm{a}$ & $17 \mathrm{a}$ & 17 & 36 & 45 & 41 \\
\hline \multirow[t]{2}{*}{$10-20$} & 449 & 506 & $477 \mathrm{~B}$ & 301 & 359 & $330 \mathrm{C}$ & 711 & 639 & $675 \mathrm{~A}$ & 60 & 51 & 55 & $55 \mathrm{a}$ & $25 \mathrm{~b}$ & 40 & 62 & 76 & 69 \\
\hline & \multicolumn{12}{|c|}{$\begin{array}{l}\text { C.V.33\% } \\
\quad \text { Outubro } 2001\end{array}$} & \multicolumn{3}{|c|}{ C.V. $52 \%$} & & & \\
\hline $0-2,5$ & $74^{\mathrm{ns}}$ & 91 & $83^{\text {ns }}$ & $150^{\mathrm{ns}}$ & 129 & 139 & $129^{\mathrm{ns}}$ & 177 & 153 & $28^{\mathrm{ns}}$ & 30 & $29 \mathrm{~A}$ & $30^{\mathrm{ns}}$ & 37 & $34 \mathrm{~A}$ & $24^{\mathrm{ns}}$ & 32 & $28 \mathrm{~A}$ \\
\hline $2,5-5$ & 69 & 105 & 87 & 121 & 120 & 121 & 137 & 157 & 147 & 17 & 18 & $18 \mathrm{~B}$ & 22 & 29 & $25 \mathrm{AB}$ & 26 & 25 & $26 \mathrm{~A}$ \\
\hline $5-10$ & 59 & 173 & 166 & 209 & 186 & 197 & 204 & 324 & 264 & 14 & 21 & $17 \mathrm{~B}$ & 18 & 23 & $21 \mathrm{~B}$ & 39 & 42 & $40 \mathrm{~A}$ \\
\hline $10-20$ & \multicolumn{15}{|c|}{ Fevereiro 2002} & \multicolumn{2}{|c|}{ C.V. $31 \%$} & \\
\hline $0-2,5$ & nd & $\mathrm{nd}$ & & $71^{\mathrm{ns}}$ & 88 & $79 \mathrm{~B}$ & $157^{\mathrm{ns}}$ & 169 & $163 \mathrm{~A}$ & $\mathrm{nd}$ & $\mathrm{nd}$ & & $24^{\mathrm{ns}}$ & 25 & $25 \mathrm{~A}$ & $16^{\mathrm{ns}}$ & 23 & $20 \mathrm{~A}$ \\
\hline $2,5-5$ & $\mathrm{nd}$ & $\mathrm{nd}$ & & 73 & 65 & $69 \mathrm{~B}$ & 150 & 118 & $134 \mathrm{~A}$ & $\mathrm{nd}$ & $\mathrm{nd}$ & & 20 & 23 & $21 \mathrm{~A}$ & 16 & 21 & $18 \mathrm{~A}$ \\
\hline $5-10$ & $\mathrm{nd}$ & $\mathrm{nd}$ & & 73 & 114 & $94 \mathrm{~B}$ & 250 & 178 & $213 \mathrm{~A}$ & $\mathrm{nd}$ & $\mathrm{nd}$ & & 20 & 21 & $21 \mathrm{~A}$ & 22 & 22 & $22 \mathrm{~A}$ \\
\hline $10-20$ & nd & nd & & 120 & 126 & $123 \mathrm{~B}$ & 403 & 287 & $\begin{array}{r}345 \mathrm{~A} \\
\mathrm{~V} .30 \%\end{array}$ & $\mathrm{nd}$ & $\mathrm{nd}$ & & 25 & 28 & $26 \mathrm{~B}$ & 41 & 49 & $\begin{array}{l}45 \mathrm{~A} \\
V .44 \%\end{array}$ \\
\hline
\end{tabular}

'PD12 = áreas com 12 anos de sistema plantio direto; TA = solo com textura argilosa; TmuA = solo com textura muito argilo sa e; TmeA = solo com textura média argilosa. ${ }^{2} \mathrm{~A}=$ sequiência de cultura Aveia -preta $/ \mathrm{milho} /$ trigo/soja e B = Aveia-preta/soja/trigo/soja; ${ }^{3} \mathrm{~m}=$ media da sequiência de cultura A e B $;{ }^{4}$ nd = Não determinado; ${ }^{5}$ Médias seguidas de mesma letra, minúscula para sucessões e maiúscula para tempo de adoção e classe textural na mesma linha, não diferem estatisticamente entre si pelo teste de Tukey a 5\%. ns = análise de variância não significativa pelo teste $\mathrm{F}$ a $5 \%$. 
As maiores e mais significativas diferenças de $\mathrm{C}$ e $\mathrm{N}$-microbiano pró PD12TmeA foram observadas na camada 10-20 cm (Tabela 8). Decorridos 32 dias do plantio do milho (nov/00), essa inversão foi revertida e a área PD12-TA apresentou $973 \mathrm{~kg} \mathrm{C}_{\mathrm{mic}}$ $\mathrm{ha}^{-1}$ e $135 \mathrm{~kg} \mathrm{~N}$ mic $\mathrm{ha}^{-1}$ enquanto a PD12-TmeA apresentou $714 \mathrm{~kg} \mathrm{C}_{\text {mic }} \mathrm{ha}^{-1}$ e $109 \mathrm{~kg}$ $\mathrm{N}_{\text {mic }}$ ha $^{-1}$ na camada $0-20 \mathrm{~cm}$.

$\mathrm{O}$ efeito positivo do sistema radicular do milho sobre o $\mathrm{C}$-microbiano na camada 10-20 cm, assim como nas áreas com diferentes tempos de adoção do SPD, também se fez notar no mês de nov/00 nas áreas com diferentes texturas. Esse efeito não se manteve do meio para o final do ciclo da cultura. Em fev/01, quando as culturas encontravam-se na fase de maturação, a biomassa microbiana nas sucessões A e B era semelhante, mas diferiu com a textura dos solos. A área PD12-TA apresentou 46 e 51\% menos C-microbiano e 37 e $32 \%$ menos N-microbiano que as áreas PD12-TmuA e PD12-TmeA. Já no intervalo entre uma cultura e outra (maio/01), quando o solo estava coberto somente com os resíduos das culturas de milho ou soja, o C-microbiano da sequiência A diferiu da sequiência B na camada 10-20cm (Tabela 8), provavelmente devido ao maior disponibilidade de matéria seca produzida pelo sistema radicular do milho do que da soja nessa camada, como demonstrado no capitulo dois desta Tese. Embora significância estatística tenha ocorrido somente na área PD12-TmuA.

Após o plantio do trigo (jun/01), as áreas PD12-TmeA e PD12-TA apresentaram $40 \%$ mais C-microbiano que a área PD12-TmuA, porem esta tinha $28 \mathrm{e}$ 18\% mais N-microbiano que as áreas PD12-TmeA e PD12-TA. Essas diferenças entre o C e N-microbiano ocorreram nas camadas de 5-10 e 10-20 cm. Dois fatores podem ter causado simultaneamente essas diferenças: alta umidade no solo decorrente de chuvas 
nos meses de maio e junho 2001 associada a adubação m plantio do trigo. Acidificação do solo pela adição de fertilizantes com a diminuição de oxigênio podem ter mudado a composição da estrutura microbiana do solo, vindo refletir nas relações $\mathrm{C}$ e $\mathrm{N}$ microbiano na área PD12-TmuA. Quanto maior o teor de argila no solo menor será o tamanho dos poros, dificultando as troca de gases entre o solo e a atmosfera, favorecendo os microrganismos anaeróbicos e aumentando o processo de denitrificação. Siqueira Neto (2003), em trabalho realizado na mesma região, verificou que o maior fluxo de $\mathrm{N}_{2} \mathrm{O}$ ocorreu no mês de junho de 2001 nas áreas PD12-TA e PD22-TA, confirmado o efeito relatado acima. Com a diminuição das chuvas e o aumento da temperatura ambiental no mês seguinte, associado ao desenvolvimento pleno da cultura de trigo (estimulo rizosferico) a área PD12-TmuA voltou a apresentar as maiores quantidades de $\mathrm{C}$ e $\mathrm{N}$-microbiano, seguida pelas áreas PD12-TmeA e PD12-TA na camada $0-20 \mathrm{~cm}$. Novamente as diferenças entre as áreas se concentraram nas camadas $5-10$ e $10-20 \mathrm{~cm}$.

Um dia após a colheita do trigo (out/01), o C e N-microbiano da camada 0-20 cm diminuíram nas áreas PD12-TmuA e PD12-TmeA em relação à amostragem anterior em decorrência da falta do estímulo rizosférico, proporcionado pelos exudados e excreções da planta de trigo. Nesse período de pequeno pousio, as potenciais fontes de nutrientes para a comunidade microbiana são a decomposição do sistema radicular e dos resíduos depositados na superfície do solo. A diferença na quantidade de $\mathrm{N}$-microbiano entre as áreas foi observada nas camadas 5-10 e 10-20cm, indica que as raízes constituíam naquele momento a principal fonte de $\mathrm{C}$ no período pós-colheita. 
Em fevereiro do ano seguinte, com a cultura da soja no início da fase de maturação, a área PD12-TmuA apresentou em media $856 \mathrm{~kg} \mathrm{C}_{\text {mic }} \mathrm{ha}^{-1}$ enquanto a área PD12-TA tinha somente $365 \mathrm{~kg} \mathrm{C}_{\mathrm{mic}} \mathrm{ha}^{-1}$ na camada $020 \mathrm{~cm}$ (Figura 6a), e a diferença ocorreu em todas as camadas do solo. $\mathrm{O}$ mesmo não ocorreu com $\mathrm{N}$-microbiano que não foi estatisticamente igual nas camadas $0-2,5 ; 2,5-5$ e $5-10 \mathrm{~cm}$. Como relatado anteriormente, o estimulo direcionado do sistema radicular da soja as bactérias, pode ter proporcionado a semelhança de N-microbiano às áreas.

No período da condução do experimento a quantidade de C-microbiano variou entre 425 e 1138 kg Cmic ha-1 na área PD12-TmeA, na área PD12-TA entre 365 e 1115 $\mathrm{kg} \mathrm{C}_{\text {mic }} \mathrm{ha}^{-1}$ e na área PD12-TmuA entre 752 e $1572 \mathrm{~kg} \mathrm{C}_{\text {mic }} \mathrm{ha}^{-1}$ na camada de 0-20 cm (Figura 6a). Esses resultados corroboram com os obtidos por Mercks et al. (1985), Ladd (1992) e Hassink (1994), onde demonstraram que solo com textura fina apresenta maior C-microbiano que solo com textura grossa. A PD12-TmuA apresentou os maiores valores de Cmicrobiano em todas as profundidades estudadas, exceto na fase vegetativa do trigo (jun/01), onde a precipitação pluviométrica e a baixa temperatura, aliado a característica física do solo foram as prováveis causas desta diminuição como relatado acima. A área PD12-TA apresentou o C-microbiano maior na camada $0-20 \mathrm{~cm}$ que a área PD12-TmeA nos meses em que não houve aplicação de fertilizantes (nov/00, maio/01, out/01) e menor ou igual nos demais (out/00 e jun/01). Por possuir maior teor de matéria orgânica e argila no solo, esperava-se que o C-microbiano fosse sempre maior na área PD12-TA. Entretanto, a diferença pró PD12-TmeA ocorreu nas camadas abaixo de $5 \mathrm{~cm}$. Talvez aspectos físicos do solo como porosidade e compactação na área PD12-TmeA tenha favorecido a lixiviação dos nutrientes no perfil do solo e o 
desenvolvimento do sistema radicular nas camadas mais profundas, resultando na maior disponibilidade de $\mathrm{C}$ assimilável. Aliado às condições ambientais favoráveis, houve aumento temporário do $\mathrm{C}$-microbiano nessas camadas, principalmente em culturas com elevada produção de massa radicular como o milho.

O efeito da sequiência de culturas nos solos com diferentes texturas também não foi possível ser verificado para o $\mathrm{N}$-microbiano na maioria das épocas de amostragem (análise de variância não significativa a $5 \%$ pelo teste $\mathrm{F}$ ).

O teor de $\mathrm{N}$-microbiano variou entre 93 e $167 \mathrm{~kg} \mathrm{~N}_{\text {mic }} \mathrm{ha}^{-1}$ na área PD12TmeA, 80 e $180 \mathrm{~kg} \mathrm{~N}_{\text {mic }} \mathrm{ha}^{-1}$ na PD12-TA e entre 94 e $189 \mathrm{~kg} \mathrm{~N}_{\text {mic }}$ ha $^{-1}$ na PD12-TmuA na camada $0-20 \mathrm{~cm}$ (Figura 6b). Em geral, a área PD12-TmuA apresentou o maior teor de $\mathrm{N}$-microbiano na camada $0-20 \mathrm{~cm}$, exceto no intervalo da colheita do milho e soja e a implantação da cultura de trigo (maio/01). Não houve predominância dos teores de $\mathrm{N}$ microbiano entre as áreas PD12-TA e PD12-TmeA na camada 0-20 cm ao longo do período (Figura 6a). Acredita-se que os tratos culturais (adubação) e a presença de resíduos radiculares, associados às condições ambientais, tenham favorecido o $\mathrm{N}$ microbiano na área PD12-TmeA em profundidade.

A correlação positiva entre o conteúdo de argila do solo e a biomassa microbiana indica que existe uma maior capacidade de proteção dos microrganismos em solos argilosos do que arenosos (Ladd et al., 1992; Hassink,1994). Constatou-se que o solo com maior teor de argila (PD12-TmuA) apresentou também maior teor de C e $\mathrm{N}$ microbianos, porem os solo com texturas próximas (PD12-TA e PD12-TmeA) demonstram semelhança nas quantidades $\mathrm{C}$ e $\mathrm{N}$-microbiano na camada superficial ( 0 5cm) (Tabela 8), mesmo com quantidade de $\mathrm{C}$ e $\mathrm{N}$-total diferentes (Tabela 6). Devido ao 
aumento da agregação das partículas proporcionado pelo emprego do SPD (Six, et al.1999) provavelmente houve uma melhoria das condições do meio físico para a BMS, que se estende para as camadas mais profundas com o tempo de adoção do sistema.

\subsubsection{Correlações entre o C e $\mathrm{N}$ microbiano e o $\mathrm{N}$ mineral no solo}

No geral, as correlações lineares do $\mathrm{C}$ e $\mathrm{N}$-microbiano com o $\mathrm{N}$-mineral foram baixas $(r=0,16$ a 0,62) nas diferentes áreas e sequiência de culturas (Tabela 9). No total das análises, o C-microbiano apresentou $r=0,36(\mathrm{P}<0,001, \mathrm{n}=1220)$ com o $\mathrm{N}$-mineral $\left(\mathrm{N}-\mathrm{NO}_{3}{ }^{-}+\mathrm{N}-\mathrm{NH}_{4}{ }^{+}\right)$do solo enquanto que o $\mathrm{N}$-microbiano apresentou $r=0,19(\mathrm{P}<$ 0,001, $\mathrm{n}=1220$ ). Em condições controladas, Deng et al. (2000) verificaram a correlação linear entre o C-microbiano e o acumulo de $\mathrm{N}$ mineralizado de $r=0,66(\mathrm{P}<0,001, \mathrm{n}=$ 44) e do $\mathrm{N}$-microbiano de $r=0,80(\mathrm{P}<0,001, \mathrm{n}=44)$ em solo incubado por 24 semanas. Esses autores concluíram que o $\mathrm{C}$ ou $\mathrm{N}$-microbiano são melhores índices para estimar o potencial de mineralização ou a disponibilidade de $\mathrm{N}$.

O C-microbiano apresentou melhor correlação com o $\mathrm{N}-\mathrm{NH}_{4}{ }^{+}$e o $\mathrm{N}-\mathrm{NO}_{3}{ }^{-}$que o N-microbiano, independente das texturas, do tempo de adoção ou da seqüência de culturas (Quadro 05). Resultados obtidos por Patra et al. (1990) em trigo em sistema convencional mostrou também fraca relação entre o $\mathrm{N}$-microbiano e o $\mathrm{N}-\mathrm{NO}_{3}{ }^{-}$e os dados apresentados por Smith (1994) mostram forte relação entre o C-microbiano e a $\mathrm{N}-\mathrm{NO}_{3}{ }^{-}$durante a absorção de $\mathrm{N}$ pela planta de trigo. Lundquist et al. (1999) verificaram que após a incorporação de centeio ao solo houve um rápido aumento seguido de diminuição do $\mathrm{C}$-microbiano, enquanto o $\mathrm{N}$-microbiano permaneceu razoavelmente constante. Os resultados mostraram que o $\mathrm{C}$-microbiano acompanhou melhor a 
dinâmica da concentração de $\mathrm{N}-\mathrm{NO}_{3}{ }^{-}$no solo do que o $\mathrm{N}$-microbiano durante as seis semanas de observação.

Tabela 9. Coeficiente de correlação linear entre o $\mathrm{C}$ e N-microbianos, $\mathrm{N}-\mathrm{NH}_{4}{ }^{+}, \mathrm{N}^{-} \mathrm{NO}_{3}{ }^{-}$e o $\mathrm{N}$-mineral $\left(\mathrm{N}-\mathrm{NH}_{4}{ }^{+}+\mathrm{N}^{-\mathrm{NO}_{3}}{ }^{-}\right)$do solo nas diferentes áreas e sequiências de culturas

\begin{tabular}{|c|c|c|c|c|}
\hline Avaliações & ${\mathrm{N}-\mathrm{NH}_{4}}^{+}$ & $\mathrm{N}^{-\mathrm{NO}_{3}}{ }^{-}$ & $\mathrm{N}_{\text {mineral }}$ & $\mathrm{n}^{3}$ \\
\hline & & $\begin{array}{l}\text { PD12 - TmeA } \\
\end{array}$ & & 260 \\
\hline $\mathrm{C}-\operatorname{mic}\left(\mathrm{kg} \mathrm{ha}^{-1}\right)$ & $0,23 * * *$ & $0,44 * * *$ & $0,39 * * *$ & \\
\hline $\mathrm{N}-\operatorname{mic}\left(\mathrm{kg} \cdot \mathrm{ha}^{-1}\right)$ & $0,09^{\dagger}$ & $0,25 * * *$ & $0,19 * *$ & \\
\hline & & PD12 - TmuA & & 320 \\
\hline $\mathrm{C}-$ mic & $0,11 *$ & $0,36 * * *$ & $0,24 * * *$ & \\
\hline $\mathrm{N}-$ mic & $0,15^{* *}$ & $\begin{array}{c}0,21 * * * \\
\text { PD12 - TA }\end{array}$ & $0,20 * * *$ & 320 \\
\hline $\mathrm{C}-$ mic & $0,27 * * *$ & $0,64 * * *$ & $0,62 * * *$ & \\
\hline $\mathrm{N}-$ mic & $-0,09^{\dagger}$ & $\begin{array}{c}0,26 * * * \\
\text { PD22 - TA }\end{array}$ & $0,17 * *$ & 320 \\
\hline $\mathrm{C}-$ mic & $0,26 * * *$ & $0,32 * * *$ & $0,38 * * *$ & \\
\hline $\mathrm{N}-\mathrm{mic}$ & $0,07^{\dagger}$ & $\begin{array}{c}0,31 * * * \\
\text { Seqüência } A^{2}\end{array}$ & $0,26 * * *$ & 620 \\
\hline $\mathrm{C}-$ mic & $0,22 * * *$ & $0,49 * * *$ & $0,39 * * *$ & \\
\hline $\mathrm{N}-$ mic & $0,12 * * *$ & $\begin{array}{c}0,28 * * * \\
\text { Sequiência B }\end{array}$ & $0,22 * * *$ & 600 \\
\hline $\mathrm{C}-$ mic & $0,16 * * *$ & $0,32 * * *$ & $0,33 * * *$ & \\
\hline $\mathrm{N}-$ mic & $0,08^{\dagger}$ & $\begin{array}{l}0,16 * * * \\
\text { Total }\end{array}$ & $0,16 * * *$ & 1220 \\
\hline $\mathrm{C}-$ mic & $0,19 * * *$ & $0,42 * * *$ & $0,36 * * *$ & \\
\hline $\mathrm{N}-$ mic & $0,10 * * *$ & $0,23 * * *$ & $0,19 * * *$ & \\
\hline
\end{tabular}

${ }^{\mathrm{T}} \mathrm{PD} 12$ e PD22 = áreas com 12 e 22 anos sob sistema plantio direto, respectivamente; TA = solo com textura argilosa; $\mathrm{TmuA}=$ solo com textura muito argilosa e $\mathrm{Tme} \mathrm{A}=$ solo com textura média argilosa.

${ }^{2}$ Sequiência de cultura $\mathrm{A}=$ milho/trigo/soja e sequiência de cultura $\mathrm{B}=$ soja/trigo/soja.

${ }^{3} \mathrm{n}=$ números de pares correlacionados

${ }^{\dagger}: P>0,05 ; *: P<0,05 ; * *: P<0,01 ; * * *: P<0,001$ 
$\mathrm{O} \mathrm{N}-\mathrm{NH}_{4}{ }^{+}$mostrou ter menor correlação com o $\mathrm{C}$ e $\mathrm{N}$-microbiano do que o $\mathrm{N}$ $\mathrm{NO}_{3}{ }^{-}$. Pelo menos três fatores contribuem para que a quantidade $\mathrm{N}-\mathrm{NH}_{4}{ }^{+}$seja instável em relação a BMS: 1) o $\mathrm{N}-\mathrm{NH}_{4}{ }^{+}$é rapidamente oxidado em $\mathrm{N}-\mathrm{NO}_{3}{ }^{-}$pelas bactérias nitrificadoras (Boer \& Kowalchuk, 2001); 2) os protozoários, ao se alimentarem das bactérias, excretam N-NH${ }_{4}^{+}$(Kuikman \& Veen, 1989; Zwart \& Darbyshire, 1992) e sua comunidade é bastante flutuante no solo (Ingham et al., 1986; Juma 1993); 3) o N-NH${ }_{4}^{+}$ por ter característica catiônica fica adsorvido na superfície das argilas (Young \& Aldag, 1985).

\subsection{Conclusões}

Com base nos resultados obtidos pode-se concluir que:

- Em função do tempo de adoção do SPD o C-microbiano aumenta em profundidade. $\mathrm{O} \mathrm{N}$ imobilizado aumenta na forma microbiana, porém apresenta maior constância na camada $0-20 \mathrm{~cm}$.

- A textura influência na quantidade de $\mathrm{C}$ e $\mathrm{N}$-microbiano. A área com maior teor de argila apresentou os maiores valores de $\mathrm{C}$ e $\mathrm{N}$-microbiano. Entretanto, solos sob SPD com texturas próximas apresentam quantidades iguais de $\mathrm{C}$-microbiano na camada de 0-5 cm durante o sistema de produção.

- Não foi possível verificar o efeito das seqüências de milho-trigo-soja e soja-trigosoja nas quantidades de $\mathrm{C}$ e N-microbiano nas áreas com 12 e 22 anos de SPD e nas diferentes texturas devido a fatores incontroláveis que impossibilitou a interpretação dos resultados com respaldo estatístico. 
- $\quad$ O C-microbiano em condições de campo apresenta melhor correlação com as quantidades de $\mathrm{N}$-mineral no solo tanto na forma de nitrato com na de amônia. 


\section{PARÂMETROS RADICULARES DO MILHO E DA SOJA SOB SISTEMA PLANTIO DIRETO E SUA INFLUÊNCIA NA BIOMASSA MICROBIANA DO SOLO}

\section{Resumo}

Parâmetros radiculares como distribuição, comprimento, diâmetro e matéria seca são inerentes a cada espécie de planta. As raízes podem influenciar a população microbiana durante o ciclo vegetativo através das rizodeposições e, após a senescência, integrando a matéria orgânica do solo. Pelo fato de representarem um substrato lábil, especialmente de nitrogênio, podem ditar o ritmo da disponibilidade de nutrientes na sequiência de culturas sob sistema plantio direto (SPD). A comparação dos sistemas radiculares de uma gramínea (milho) e uma leguminosa (soja) e sua influência sobre a distribuição espacial do $\mathrm{C}$ e $\mathrm{N}$ microbianos foram feitas em um Latossolo vermelho-escuro, textura argilosa, cultivados há 22 anos sob SPD, no município de Tibagi (PR). Técnicas de processamento de imagens e de placa de pregos foram empregadas na avaliação de 40 quadrículas de um perfil de $80 \times 50 \times 3 \mathrm{~cm}$, revelando que $36 \%$ das raízes de milho e $30 \%$ das raízes de soja estão concentradas na camada $0-10 \mathrm{~cm}$ do solo. A distribuição percentual no perfil do solo de matéria seca radicular foi semelhante nas duas culturas. $\mathrm{O}$ sistema radicular do milho apresentou um total de $1324 \mathrm{~kg} \mathrm{C}^{-1}$ e $58 \mathrm{~kg} \mathrm{~N}^{-1}$, com maior densidade por comprimento e por matéria seca e raízes em vias de decomposição 
na camada superficial do solo, decrescendo com a profundidade. O sistema radicular da soja (392 $\mathrm{kg} \mathrm{C}$ ha $^{-1}$ e $21 \mathrm{~kg} \mathrm{~N} \mathrm{ha}^{-1}$ ) teve contribuição maior de raízes finas e densidade por comprimento do que o milho. O efeito das raízes do milho sobre o C-microbiano chega a camadas mais profundas do que o das raízes da soja. $\mathrm{O} \mathrm{N}$-microbiano apresentou melhor correlação com a concentração de raízes finas ativas e com as raízes em decomposição ou de forma indefinida, provavelmente seja devido a maior quantidade de $\mathrm{C}$ e $\mathrm{N}$ de fácil assimilação pelos microrganismos.

\section{Summary}

Some root parameters like distribution, length, diameter and dry matter are inherent to each plant specie. Roots can influence the microbial population during vegetative cycle trough the rhizodeposits and, after senescence, integrating the soil organic matter pool. Since they represent a labile subtracts, especially of nitrogen, they can determine the rate of nutrient availability to the next crop cultivated under no-tillage (NT). We compared the root systems of a grass (corn) with a legume (soybean) and their influence on spatial distribution of the microbial $\mathrm{C}$ and $\mathrm{N}$ in a Latossolo vermelho-escuro soil of loamy texture, cultivated for 22 years under NT, located in Tibagi (PR). Digital image processing and nails plate techniques were used to evaluate 40 square parts of a $80 \times 50 \times 3 \mathrm{~cm}$ profile, showing that $36 \%$ and $30 \%$ of the corn and soybeans roots are concentrated in the $010 \mathrm{~cm}$ soil layer. The percentual distribution of root dry matter was similar for both crops. The corn roots presented a total of $1324 \mathrm{~kg} \mathrm{C} \mathrm{ha}^{-1}$ and $58 \mathrm{~kg} \mathrm{~N}^{-}$ 1 , with greater density per length and per mass and more roots in decomposition in the upper soil layer, decreasing with depth. The soybean roots $\left(392 \mathrm{~kg} \mathrm{C} \mathrm{ha}^{-1}\right.$ and $21 \mathrm{~kg} \mathrm{~N}$ 
$\mathrm{ha}^{-1}$ ) showed more fine roots and density per length than the corn. The corn roots stimulated microbialC till deeper soil layers than the soybean roots. The microbial $\mathrm{N}$ was presented a better correlation with the concentration of fine active roots and with roots in decomposition or in indefinite shape, possibly due to a greater concentration of $\mathrm{C}$ and $\mathrm{N}$ easily assimilated by soil microorganisms.

\subsection{Introdução}

$\mathrm{O}$ sistema plantio direto (SPD) tem potencial para aumentar o $\mathrm{C}$ orgânico do solo. Diversos estudos têm afirmado que o ato de semear sem o prévio revolvimento total do solo, a rotação de culturas e a permanência dos resíduos na superfície do solo são os principais procedimentos que resultam no aumento do C orgânico no solo (Staley, et al. 1988; Carter, 1992; Sá et al. 2001). Gale \& Cambardella (2000), usando aveia marcada com ${ }^{14} \mathrm{C}$ como traçador, demonstraram que um ano após a incorporação $42 \%$ dos resíduos remanescentes no solo eram provenientes das raízes, enquanto que $16 \%$ provinham dos resíduos deixados na superfície. O sistema radicular das plantas superiores, que ocupa menos 1\% do volume do solo (Barber, 1995), além de influenciar as características químicas, físicas e/ou biológicas ao seu redor (Rovira, 1979) exerce, portanto, também a função de aumentar o estoque de carbono no solo sob SPD.

Do ponto de vista agronômico, é desejável que o sistema radicular seja abrangente e extenso. A densidade de raízes no solo varia com as espécies vegetal. Situa-se na faixa de 1 a $5 \mathrm{~cm} \mathrm{~cm}^{-3}$ na camada superficial do solo nas culturas anuais, chegando até a $50 \mathrm{~cm} \mathrm{~cm}^{-3}$ nas gramíneas perenes (Barder, 1995). Biologicamente, sua importância reside na qualidade e também na produção de matéria seca. Estima-se que 
cerca de $60 \%$ dos fotoassimilados sejam translocados para as raízes, e destes, $50 \%$ são liberados na forma de $\mathrm{CO}_{2}$ durante a respiração. Os outros $50 \%$ são utilizados no crescimento das raízes ou depositados no solo na forma de exsudatos, mucilagem, lisados e outras formas, chamadas de rizodepósitos (Bolton Junior et al., 1993; Moreira e Siqueira, 2002), que são fonte de energia e nutrição para os microrganismos. O efeito estimulante sobre a biomassa microbiana varia com as características do meio físico e com a fisiologia, morfologia e arquitetura do sistema radicular de cada espécie vegetal. De um modo geral, as leguminosas apresentam efeito mais pronunciado por matéria seca de raiz, porém as gramíneas, por terem sistema radicular mais desenvolvido e de renovação mais intensa, apresentam efeito total maior (Rovira, 1979, Lynch, 1982). Cattelan \& Vidor (1990), em estudo realizado em sete sistemas de rotação e sucessão de culturas no Rio Grande do Sul, observaram que os sistemas com maior produção de fitomassa e acúmulo de resíduos, constituídos basicamente de gramíneas, apresentaram os maiores teores de C-microbiano na camada $0-5 \mathrm{~cm}$ do solo. Os autores atribuíram o efeito em parte ao estímulo da rizosfera sobre os microrganismos.

Estudos de avaliação do sistema radicular da cultura de grãos em solos brasileiros são raros, principalmente sob sistema de plantio direto. A quantificação de raízes é um dos processos mais dispendiosos em termos financeiros, de trabalho e de tempo, porém é um parâmetro eficaz para avaliar os efeitos do uso da terra sobre o solo (compactação) e as plantas (crescimento radicular). Nos últimos anos a avaliação da distribuição das raízes foi facilitada pelo surgimento de novas metodologias como o processamento de imagens digitais. 
Nesse contexto, o objetivo deste trabalho foi avaliar o efeito da distribuição, comprimento, diâmetro e a matéria seca do sistema radicular de uma gramínea (milho) e uma leguminosa (soja) e sua influência sobre os teores de $\mathrm{C}$ e $\mathrm{N}$ microbiano do solo sob sistema de plantio direto.

\subsection{Material e Métodos}

\subsubsection{Localização da área de amostragem e trato cultural}

Os trabalhos foram realizados na Fazenda Santa Branca, município de Tibagi no Paraná $\left(24^{\circ} 26^{\prime} \mathrm{S}\right.$ e $\left.50^{\circ} 23^{\prime} \mathrm{O}\right)$, em um solo classificado como Latossolo vermelho-escuro com classe textural argilosa $\left(420,80\right.$ e $500 \mathrm{~g} \mathrm{~kg}^{-1}$ solo de argila, silte e areia, respectivamente). A área se encontrava há 22 anos sob plantio direto com otação de soja, milho, trigo e aveia-preta nos últimos 10 anos. Outras características físicas e químicas do solo foram detalhadas por Sá et al. (2001). No milho Cargill 909 foram aplicados $400 \mathrm{~kg} \mathrm{ha}^{-1}$ de adubo (20-00-10) no plantio e após 20 dias mais $200 \mathrm{~kg} \mathrm{ha}^{-1}$ de sulfato de amônia. Na soja Embrapa 59 foram aplicados $200 \mathrm{~kg} \mathrm{ha}^{-1}$ de Super Simples e manganês (Starter $2 \mathrm{~L} \mathrm{ha}^{-1}$ ) + cobalto e molibdênio (Stoler $150 \mathrm{~mL} \mathrm{ha}{ }^{-1}$ ). As sementes de soja foram inoculadas com rizóbio Ceotec (150 g inoculante $100 \mathrm{~kg}^{-1}$ semente) e

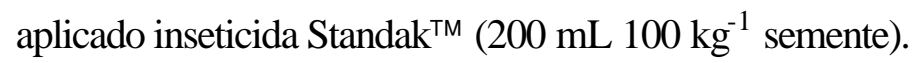

\subsubsection{Avaliação do sistema radicular do milho e da soja}

A amostragem do sistema radicular do milho foi realizada quando a cultura se encontrava no estádio de emissão do pendão e a da soja no estádio R1 da escala de Fehr et al. (1971), que corresponde ao início do florescimento. Foram abertas três trincheiras 
em cada local, analisando-se o sistema radicular numa das paredes, perpendicular às linhas de plantio, duas consecutivas no milho e três na soja.

O método empregado para a avaliação do sistema radicular foi o processamento de imagens digitais (Crestana et al., 1994; Fante Júnior, 1997) associado ao da placa de pregos (Schurmann \& Goedewaagen, 1971; Bohm, 1979), visando quantificar a distribuição no perfil do solo, o comprimento, o diâmetro e a matéria seca. O perfil do solo foi filmado com uma câmara de vídeo, tomando-se imagens separadas de cada um dos retículos de 10 x $10 \mathrm{~cm}$ delimitados com fios de nylon em um quadro de madeira de 80 x $50 \mathrm{~cm}$ fixado à parede do perfil a partir da superfície. Um total de 40 imagens por perfil ou 120 imagens por cultura foram digitalizadas e processadas inicialmente em COREL DRAW® para melhorar a qualidade das imagens. Em seguida o programa SIARCS (Sistema Integrado para Análise de Raízes e Cobertura do Solo) desenvolvido pela EMBRAPA (Crestana et al., 1994) foi usado para determinar a distribuição espacial por comprimento das raízes. Após a gravação das imagens, foi cravada uma placa de 80 x $50 \mathrm{~cm}$ no mesmo local com pregos de $3 \mathrm{~cm}$ de comprimento espaçados uniformemente a cada 2,5 x 2,5 cm. A camada de solo presa juntamente com as raízes das plantas no retículo de pregos foi destacada do perfil, aparada quando necessário, de maneira a resultar também em 40 amostras de cada trincheira, com volume de 10 × 10 × $3 \mathrm{~cm}$ por perfil ou 120 por cultura (Figura 7). 


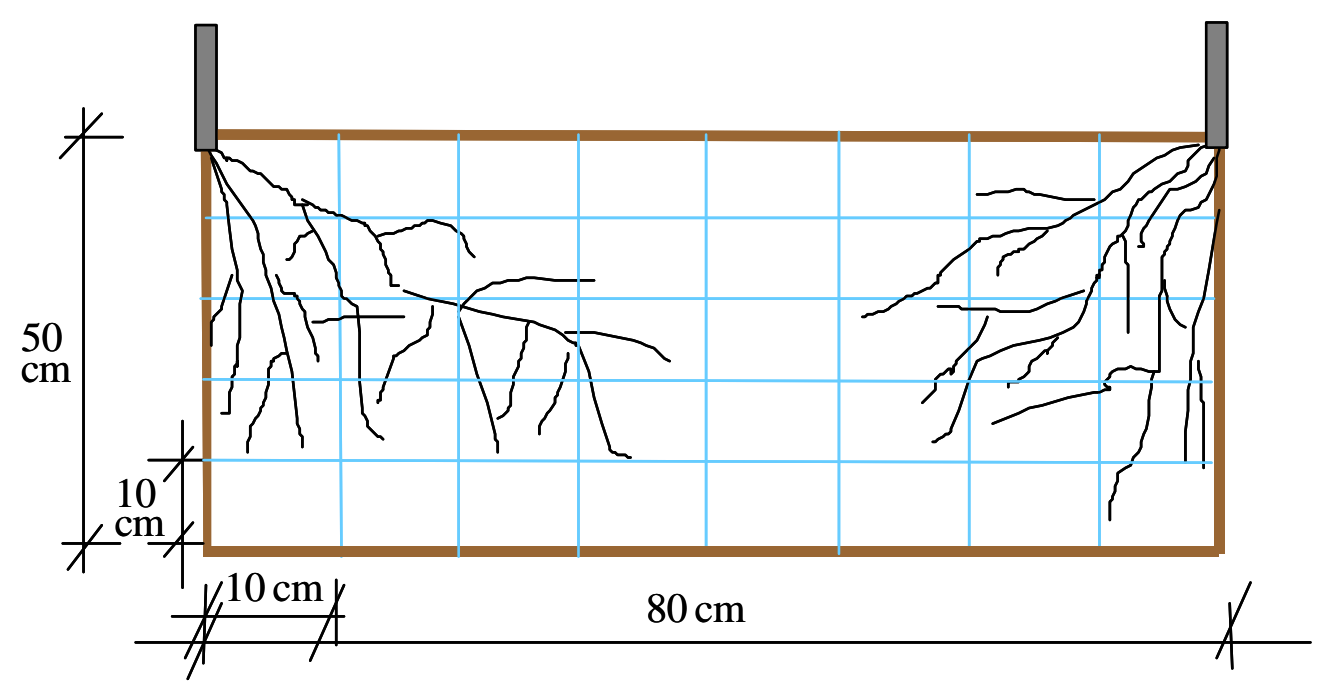

Figura - 7 Representação da amostragem do sistema radicular na cultura do milho

No laboratório procedeu-se a separação das raízes da terra com auxílio de pinça e peneira de $0,5 \mathrm{~cm}$ de abertura de malha. As amostras de solo foram analisadas quanto aos teores de $\mathrm{C}$ e $\mathrm{N}$-microbiano e total. As raízes foram lavadas em água para a completa remoção da terra aderida as mesmas, separadas por classes de diâmetro (raízes finas e raízes grossas) e colocadas em cuba com água sobre um "scanner" de mesa para obtenção de imagens digitais. Essas imagens foram processadas como especificado anteriormente para obtenção das grandezas: DMSR = densidade de matéria seca radicular (matéria seca de raízes íntegras por volume de solo amostrado); DCR = densidade de comprimento radicular (comprimento de raízes por volume de solo amostrado); matéria seca de raízes com forma indefinida ou em fase de decomposição; e diâmetro radicular, obtido através da divisão entre o comprimento e a superfície radicular (Fante Júnior, 1997). As raízes foram secas em estufa a $60^{\circ} \mathrm{C}$ por 24 horas para determinação da matéria seca. 


\subsubsection{Determinação dos teores de $\mathrm{C}$ e $\mathrm{N}$ das raízes, do solo e microbiano.}

Após as determinações físicas das raízes, as mesmas foram secas ao ar, moídas em moinho de aço inox para passar na peneira de $150 \mu \mathrm{m}$ e submetidas à determinação do teor de $\mathrm{C}$ e $\mathrm{N}$ total pelo método de combustão a seco em autoanalisador CN-2000 LECOß. O mesmo procedimento de preparo foi aplicado para a determinação do $\mathrm{C}$ e $\mathrm{N}$ total nas amostras de solo.

O C e N-microbianos foram avaliados respectivamente pelo método da fumigação-extração (Brookes et al.,1985 e Vance et al., 1987), com a utilização do fator de correção $k_{\mathrm{EC}}=0,33$ (Sparling \& West, 1988) e pelo método da quantificação dos compostos reativos à ninidrina (Joergensen \& Brookes, 1990), aplicando o fator de conversão $k_{\mathrm{EN}}=6,5$ (Sparling, et al., 1993).

\subsubsection{Análises estatísticas}

As médias obtidas em três repetições (trincheiras) das oito colunas $(10 \mathrm{x} 10 \mathrm{~cm})$ em cada uma das cinco camadas do solo para a avaliação dos sistemas radiculares das culturas do milho e da soja foram comparadas pelo teste Student. O programa de análise estatística SAS (SAS Institute, 1987), procedimento TTEST, foi utilizado para comparar os dois grupos de observações independentes. Foi realizada também a análise de correlação linear simples de Pearson (procedimento CORR do SAS) entre as variáveis de interesse. 


\subsection{Resultados e discussão}

\subsubsection{Distribuição, comprimento, diâmetro e matéria seca do sistema radicular do milho e da soja}

A distribuição do sistema radicular das plantas de milho e soja, obtida pelo método da filmagem do perfil do solo $(50$ x $80 \mathrm{~cm})$ está representada na Figura 8 . Na cultura do milho predominaram as raízes com comprimento maior que $1 \mathrm{~cm}$ enquanto que na soja predominaram as menores que $1 \mathrm{~cm}$. Na camada superficial de $4 \mathrm{~cm}$, as raízes do milho abrangeram toda a extensão de $80 \mathrm{~cm}$ entre plantas com comprimento de raízes maior que $2 \mathrm{~cm}$, enquanto que a soja, com a distância de $40 \mathrm{~cm}$ entre plantas, apresentou raízes com comprimento menor que $1 \mathrm{~cm}$ (Figura 8).

Na cultura do milho $36 \%$ do total das raízes concentraram-se na camada de 0 $10 \mathrm{~cm}$ do solo enquanto que na cultura da soja $30 \%$, com pronunciada distinção na constituição, ou seja, $28 \%$ de raízes finas no caso do milho contra $92 \%$ de raízes finas no caso da soja (Figura 9). Entende-se por raízes finas aquelas com diâmetro inferior ou igual a $0,12 \mathrm{~cm}$, observado no processamento das imagens. A maior quantidade de raízes finas da soja proporciona maior superfície de contato com a matriz do solo, resultando em maior capacidade de exploração do meio. Para os microrganismos, em especial as bactérias, essa característica é desejável devido à sua pequena mobilidade, porém não assegura um efeito mensurável sobre os microrganismos em geral, principalmente os saprófitos. 




Figura 8 - Representação gráfica da distribuição do sistema radicular do milho (a) e da soja (b) no perfil do solo $(50 \times 80 \mathrm{~cm})$. Gráficos construídos com resultados de comprimentos de raízes (média de três repetições) calculados pelo programa SIARCS em regiões de $2 \times 2 \mathrm{~cm}$, a partir de imagens obtidas por filmagens em regiões de $10 \times 10 \mathrm{~cm}$ 


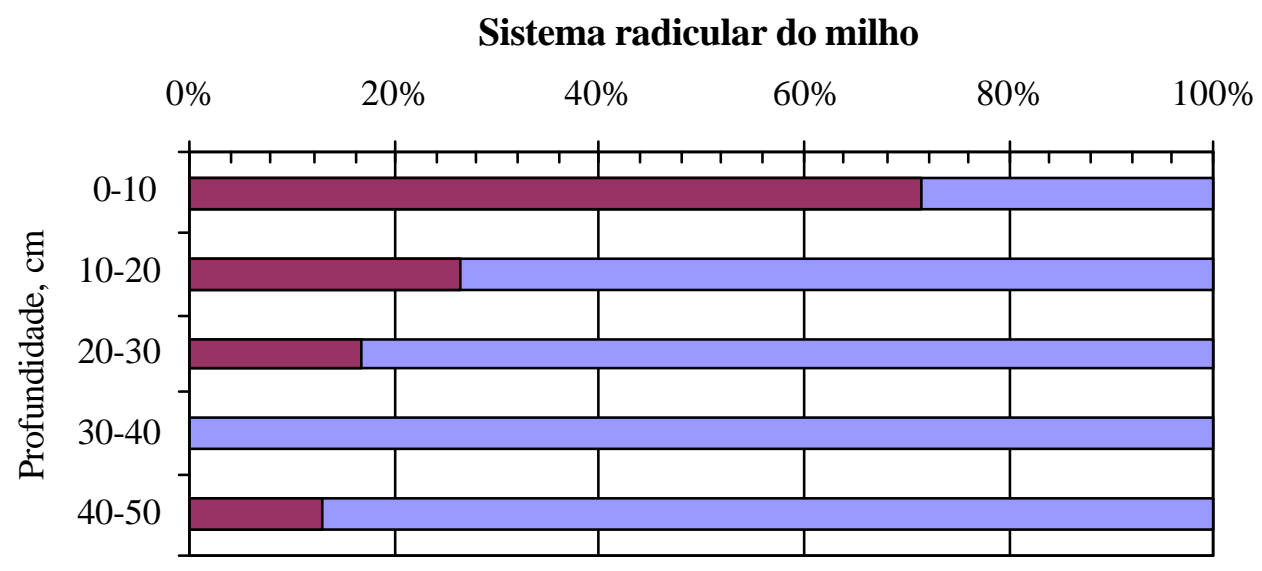

Sistema radicular da soja

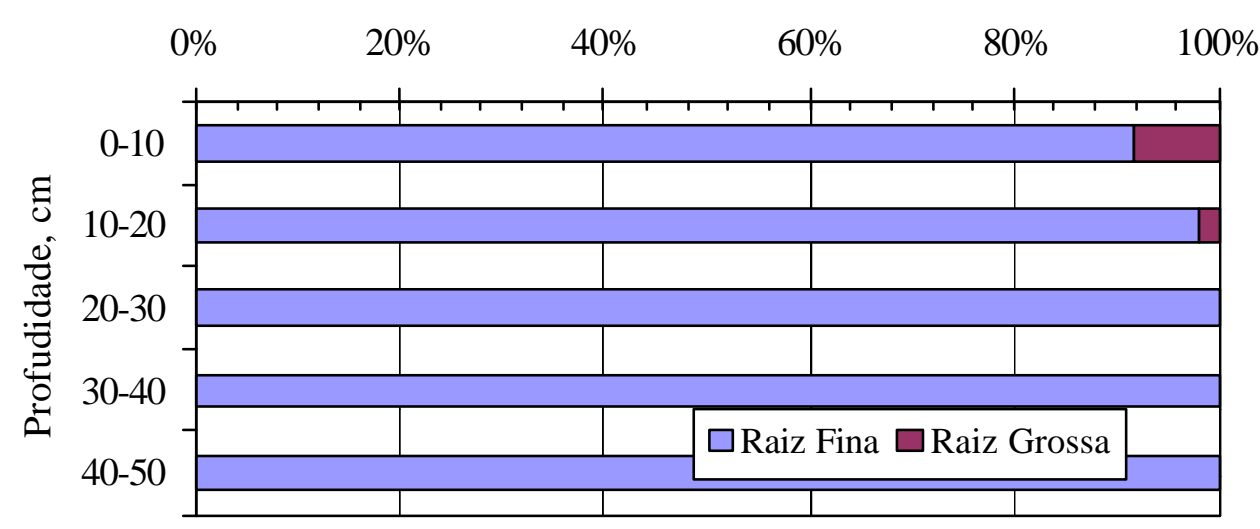

Densidade radicular por densidade, $\mathrm{cm} \mathrm{cm}^{-3}$

Figura 9 - Contribuição das raízes grossas (diâmetro $>0,12 \mathrm{~cm}$ ) e finas (diâmetro $\leq$ $0,12 \mathrm{~cm}$ ) no sistema radicular do milho e da soja

O solo sob cultura da soja apresentou de 1,7 a 2,8 vezes maior densidade de comprimento radicular (DCR) por $\mathrm{cm}^{-3}$ de solo que o milho (Figura 10) e, ao contrário deste, sem diminuição em profundidade. Como relatado acima, as raízes finas da soja são as principais contribuintes para esta alta DCR.

A média da densidade de matéria seca radicular (DMSR) por $\mathrm{cm}^{-3}$ de solo da soja foi estatisticamente igual à do milho, exceto na camada 30-40cm (Figura 10). Apesar disso, o milho apresentou 78 e 134\% mais DMSR que a soja nas camadas 0-10 e 10- 
20cm. A analise da distribuição das raízes das duas culturas (Figura 8) e o aumento do diâmetro das raízes do milho nas camadas $30-40$ e 40-50cm em relação à camada 2030cm (Figura 10), sugere haver adensamento do solo a cerca de $15 \mathrm{~cm}$ de profundidade. A soja apresentou maior média de DMSR nas camadas mais profundas do que o milho, provavelmente porque suas raízes mais finas tiveram maior facilidade para atravessar essa camada compactada, como já verificado em outras culturas por Shierlaw \& Alton (1984). Em decorrência, o efeito de impedimento à penetração foi menor na cultura da soja que na do milho.

Os diâmetros das raízes da soja e do milho foram estatisticamente iguais na camada superficial do solo $(0-10 \mathrm{~cm})$, enquanto nas demais o do milho foi de 0,8 a 2,8 vezes maior do que da soja (Figura 10). Essa característica física das raízes é muito importante para a sustentabilidade do SPD. Nesse sistema, onde não há revolvimento do solo e ocorre intenso tráfico de máquinas (Tormena, 1995), a existência dos canais de grande diâmetro deixados pelas raízes e pela fauna é imprescindível, pois é através deles que se darão a infiltração de água e as trocas de gases.

O milho apresentou 3,5 vezes mais raízes em fase de decomposição ou com forma indefinida do que a soja no perfil (Figura 10). Em geral, as gramíneas apresentam maior taxa de renovação das raízes do que as leguminosas (Lynch, 1982), produzindo maior quantidade de matéria seca ao longo do ciclo. 

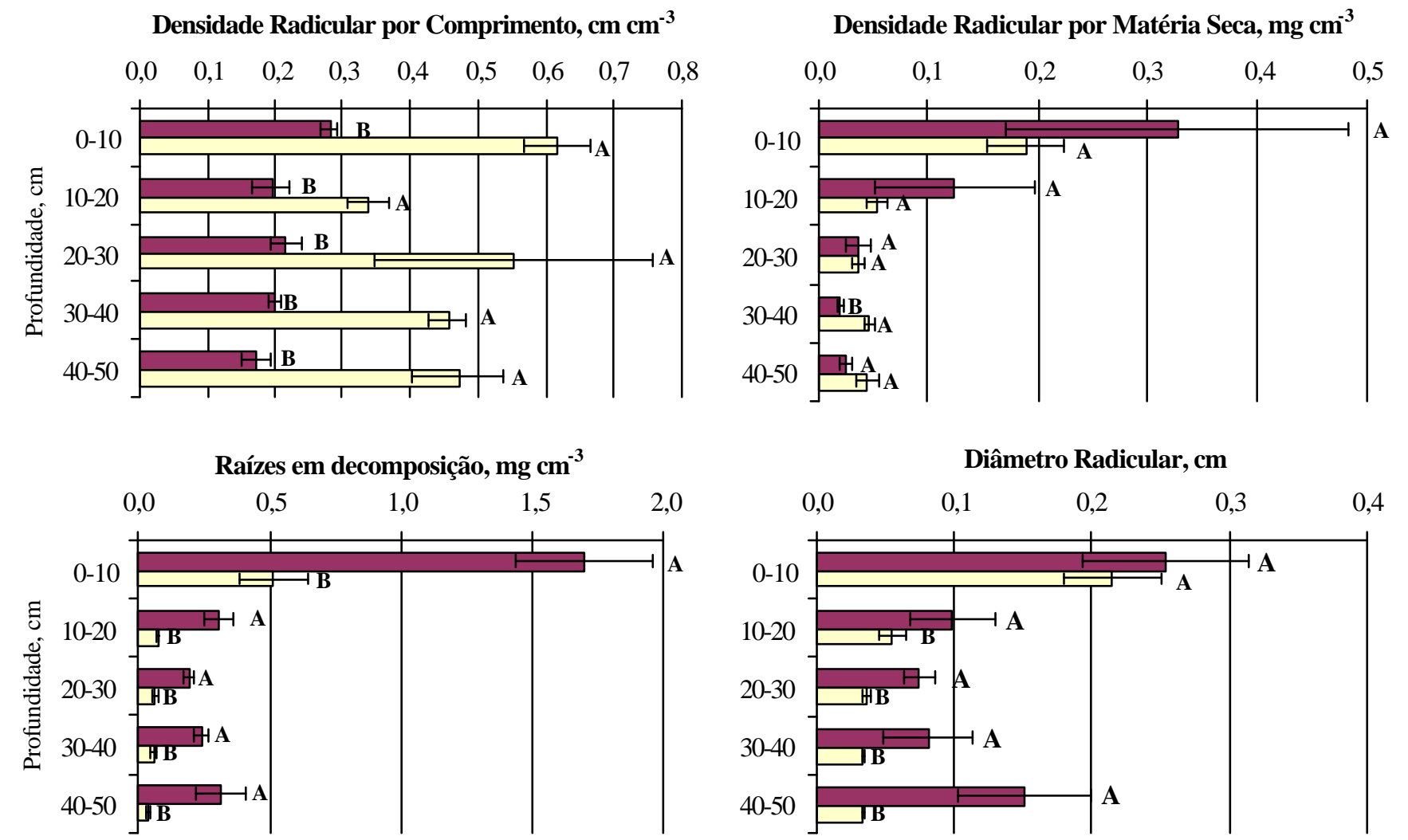

$\square$ Milho

$\square$ Soja

Figura 10. Parâmetros radiculares do milho e da soja em solo sob sistema plantio direto. Média de três repetições \pm erro padrão. As médias seguidas de mesma letra na profundidade não diferem entre si pelo teste Student a 5\% 
O sistema radicular do milho apresentou no momento da coleta um total de 1324 $\mathrm{kg} \mathrm{C} \mathrm{ha}{ }^{-1}$ e $58 \mathrm{~kg} \mathrm{~N} \mathrm{ha}^{-1}$ na camada $050 \mathrm{~cm}$ e a soja $392 \mathrm{~kg} \mathrm{C} \mathrm{ha}^{-1}$ e $20,7 \mathrm{~kg} \mathrm{~N} \mathrm{ha}^{-1}$ (Tabela 10), ou seja, cerca de 3,5 vezes mais $\mathrm{C}$ e 2,5 vezes mais $\mathrm{N}$. O milho, por ser planta de ciclo fotossintético $\mathrm{C}_{4}$, tem grande capacidade de fixação de carbono, com produção de matéria seca acima e abaixo da superfície do solo maior que a da soja. Entretanto, a distribuição percentual de matéria seca radicular total (raízes ativas mais raízes em decomposição) nas camadas de solo analisadas foi semelhante entre as duas culturas $(61,13,7,8$ e $10 \%$ para o milho e $61,12,9,10$ e $8 \%$ para a soja) pelo método da placa de prego. Isso significa que os efeitos gerados por estas características do sistema radicular da soja e do milho sobre a biomassa microbiana, guardadas as proporções de quantidade de matéria seca, tiveram a mesma distribuição no solo sob plantio direto, uma vez que o importante para os microrganismos não é só a quantidade e a qualidade das raízes e dos rizodepósitos, mas também a localização das mesmas no perfil do solo.

Tabela 10. Quantidades de C e N nas diferentes classes de raízes do milho e da soja em solo sob sistema plantio direto

\begin{tabular}{|c|c|c|c|c|c|c|}
\hline \multirow{2}{*}{ Classes de Raízes } & \multicolumn{3}{|c|}{ Milho } & \multicolumn{3}{|c|}{ Soja } \\
\hline & $\mathrm{C}$ & $\mathrm{N}$ & $\mathrm{C} / \mathrm{N}$ & $\mathrm{C}$ & $\mathrm{N}$ & $\mathrm{C} / \mathrm{N}$ \\
\hline & \multicolumn{3}{|c|}{----- $\mathrm{kg} \mathrm{ha}^{-1}$} & \multicolumn{3}{|c|}{----- $\mathrm{kg} \mathrm{ha}^{-1}$} \\
\hline Fina & $84 *$ & 4,3 & 20 & 90 & 4,5 & 20 \\
\hline Grossa & 112 & 4,5 & 25 & 50 & 1,6 & 30 \\
\hline Decomposição & 1127 & 49,2 & 23 & 252 & 14,6 & 17 \\
\hline Total & 1323 & 58,0 & 23 & 392 & 20,7 & 20 \\
\hline
\end{tabular}

* Média de três trincheiras.

Obs. A classe de raízes em decomposição inclui as raízes com forma indefinida 
A quantidade de $\mathrm{C}$ e $\mathrm{N}$ nas raízes finas do milho e da soja no momento da coleta foram similares, sendo que as raízes do milho apresentaram $84 \mathrm{~kg} \mathrm{C} \mathrm{ha}^{-1}$ e 4,3 $\mathrm{kg} \mathrm{N} \mathrm{ha}^{-1}$ e das raízes da soja com $90 \mathrm{~kg} \mathrm{C} \mathrm{ha}^{-1}$ e 4,5 $\mathrm{kg} \mathrm{N} \mathrm{ha}^{-1}$. Já as raízes grossas, o milho apresentou mais que o dobro de $\mathrm{C}\left(112 \mathrm{~kg} \mathrm{C} \mathrm{ha}^{-1}\right)$ do que a soja $\left(50 \mathrm{~kg} \mathrm{C} \mathrm{ha}^{-1}\right)$ (Tabela 10). Entretanto, a maior contribuição de $\mathrm{C}$ e $\mathrm{N}$ para o solo são as raízes em decomposição. No milho as raízes constituíam uma fração de $1127 \mathrm{~kg} \mathrm{C}$ ha $^{-1}$ e 49,2 kg N $\mathrm{ha}^{-1}$ na camada de $0-50 \mathrm{~cm}$ do solo, bem maior que as raízes da soja, com $252 \mathrm{~kg} \mathrm{C} \mathrm{ha}^{-1} \mathrm{e}$ 14,6 $\mathrm{kg} \mathrm{N} \mathrm{ha}^{-1}$. De qualquer forma, pode-se dizer que essa classe de raízes constitui a principal fonte quantitativa de nutrientes para os microrganismos em ambas as culturas. Com isso pode ocorrer simultaneamente imobilização e mineralização dos nutrientes no solo, principalmente o $\mathrm{N}$ mineral. Todavia a intensidade do impacto desse processo na matéria orgânica do solo (MOS) remanescente motiva controvérsia. Há relatos de aumento (Billes \& Botter, 1981; Cheng \& Coleman, 1990; Qian et al., 1997), de redução (Jenkinson, 1977; Sparling et al., 1982; Fisher \& Gosz, 1986), e de manutenção (Cuenca et al., 1983) da taxa de decomposição da MOS na presença do sistema radicular. A discrepância desses resultados reflete a diversidade de solos utilizados, espécie de planta, método experimental e a complexidade das interações planta-solo no estudo da dinâmica da MOS.

\subsubsection{Biomassa microbiana no perfil do solo}

A média de C-microbiano por camada de solo sob influência do sistema radicular do milho diminuiu com o aumento da profundidade de 526 para $322 \mathrm{mg} \mathrm{C} \mathrm{kg}$ ${ }^{1}$ solo, e a da soja de 473 para $211 \mathrm{mg} \mathrm{C} \mathrm{kg}^{-1}$ solo (Figura 11). As diferenças significativas 
entre as duas culturas ocorreram nas camadas $010,30-40$ e $40-50 \mathrm{~cm}$, sendo que nas duas últimas foram mais pronunciadas em decorrência da diferença na quantidade de raízes em decomposição ou com forma indefinida (Figura 10). O C-microbiano foi estimulado pelo sistema radicular do milho, que chegou a camadas mais profundas do que o da soja, efeito evidenciado também pela maior relação entre o Gmicrobiano e o C-total (Cmic:C-total) destas camadas. Em resumo, existe maior quantidade de C disponível nessas camadas sob cultura de milho para formação e manutenção da biomassa microbiana.

A relação Cmic:Ctotal no milho praticamente não diminuiu com o aumento da profundidade (de 26 para $25 \mathrm{mg}: \mathrm{g}$ ) como œorreu na soja (de 25 para $18 \mathrm{mg}: \mathrm{g}$ ). Esses resultados diferem dos encontrados por Sparling (1992) e Haynes (1999) em solo de clima temperado, que relatam diminuição da relação Cmic:Ctotal com o aumento da profundidade. Estão de acordo, no entanto, com os de Venzke Filho (1999) e Sá, J. (2001) obtidos na mesma área deste estudo em 1997. Os resultados obtidos recentemente por Balota et al. (2003) mostram a constância da relação Cmic:Ctotal em profundidade no sistema convencional, enquanto no SPD ela foi dependente da seqüência de culturas utilizada. Nas sequiências milho-trigo e algodão-trigo foi verificado um decréscimo com o aumento da profundidade enquanto na seqüência soja-trigo a relação não se alterou com a profundidade. Contudo, nos trabalhos mencionados, as amostragens de solo foram realizadas sem a presença do sistema radicular ativo, o que pode ter influenciado os resultados por não levar em consideração a qualidade da entrada do $\mathrm{C}$ no solo via rizodepósitos. 


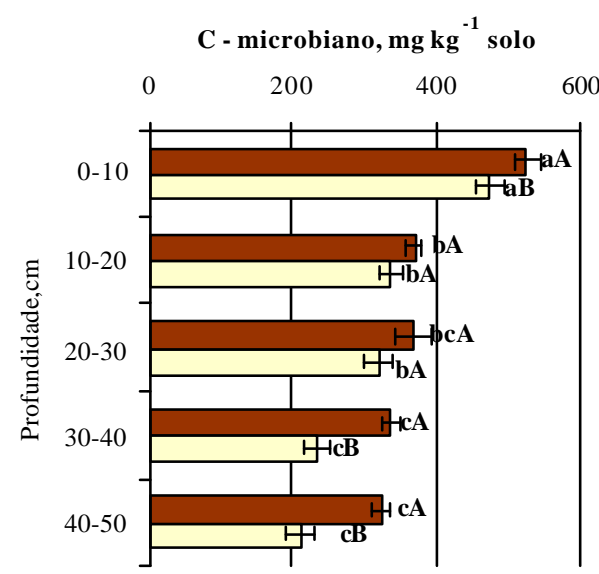

Cmic:Ctotal (mg:g)
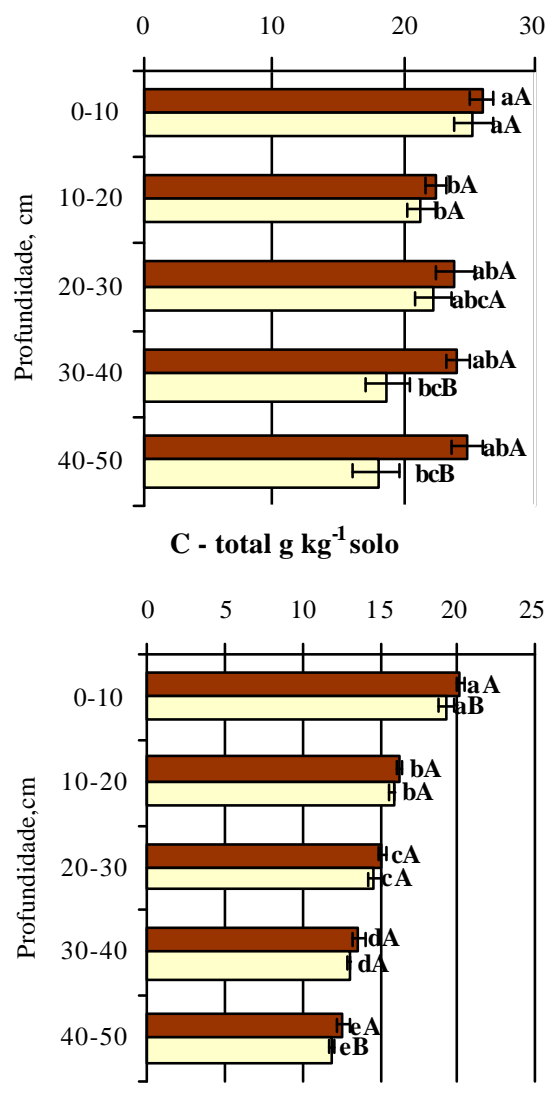

$\mathrm{N}$ - microbiano, $\mathrm{mg} \mathrm{kg}^{-1}$ solo
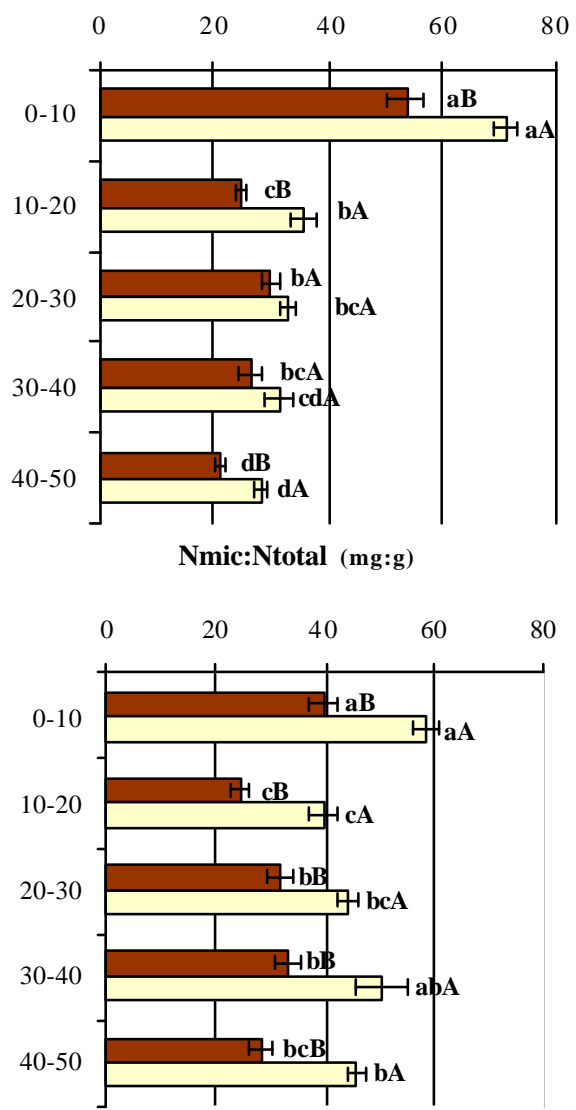

$\mathrm{N}$ - total $\mathrm{g} \mathrm{kg}^{-1}$ solo

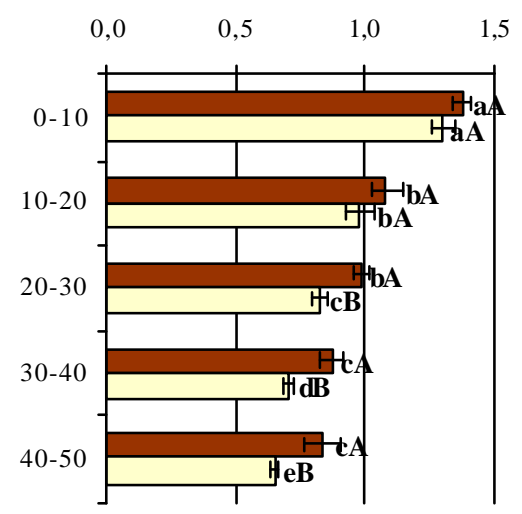

Culturas

Milho

Soja

Figura 11 - C e N microbiano e sua relação com C e N total sob influência do sistema radicular do milho e da soja em solo sob sistema plantio direto. As médias seguidas de mesma letra na profundidade não diferem entre si pelo teste Student a 5\%. Média de três repetições \pm erro padrão 
A cultura do milho apresentou maior teor de $\mathrm{C}$ total do que a da soja nas camadas 010 e $40-50 \mathrm{~cm}$ (Figura 11) e $\mathrm{N}$ total maior nas três camadas mais profundas. Os pequenos aumentos de $\mathrm{C}$ e $\mathrm{N}$ nessas camadas provavelmente se devem à maior rizodeposição e à renovação de raízes da planta de milho ao longo do ciclo da cultura, sendo que a quantidade de rizodepósitos produzido pela planta é proporcional à quantidade de C total fixado pela planta (Bolton Junior et al., 1993).

Os teores de Nmicrobiano apresentaram decréscimo com a profundidade do solo em ambas as culturas (Figura 11). No milho diminuiu de 54 para $21 \mathrm{mg} \mathrm{N} \mathrm{kg}^{-1}$ solo e na soja de 71 para $28 \mathrm{mg} \mathrm{N} \mathrm{kg}^{-1}$ solo no perfil do solo analisado. $\mathrm{O} \mathrm{N}$-microbiano foi maior na soja do que no milho em todas as camadas com diferença estatisticamente significante nas camadas 0-10, 10-20 e 40-50cm. De maneira geral, o estímulo rizosférico das leguminosas atua mais no crescimento das bactérias gran-negativas do que nos fungos. As bactérias parecem ser favorecidas: 1) pela rizodeposição rica em aminoácidos (Ayers \& Thornton, 1968; Vancura \& Hanzlikova, 1972; Jones, 1999) e açúcares solúveis das leguminosas (Jensen, 1996); 2) pela resistência aos antibióticos, abundantes na rizosfera devido ao antagonismo entre os microrganismos (Moreira e Siqueira, 2002); e 3) pela taxa de crescimento mais lenta dos fungos apresentada, em geral, nos meios de cultura artificiais. Sob influência desses fatores, o número de bactérias aumenta rapidamente no solo sob efeito das raízes e, por apresentarem relação C:N mais estreita do que os fungos (Hunt et al., 1987), podem contribuir significativamente com o aumento da concentração de $\mathrm{N}$-microbiano na rizosfera.

A relação entre o Nmicrobiano e o $\mathrm{N}$ total (Nmic:Ntotal) foi maior na cultura da soja do que no milho em todas as camadas, com distribuição semelhante no perfil do 
solo. Essa diferença na relação Nmic:Ntotal induz a conclusão de que pode ter havido alteração quantitativa da comunidade microbiana sob efeito das raízes. Tal afirmação é baseada em diversos estudos onde as plantas foram consideradas o principal agente determinante da estrutura da comunidade microbiana do solo (Rovira, 1959; Miller et al, 1989; Grayston 1998).

Esse aumento da relação Nmic:Ntotal na cultura da soja pode ser benéfico a cultura subseqüente. Segundo McGill et al. (1988), essa relação expressa melhor a fração mais facilmente mineralizável de $\mathrm{N}$ do que a quantidade do $\mathrm{N}$-microbiano. Portanto, os resultados permitem inferir que a cultura subseqüente à soja encontrará um solo com maior potencial de mineralização de $\mathrm{N}$ do que após a cultura do milho.

\subsubsection{Relação entre o C e N microbiano e os parâmetros radiculares do milho e da soja.}

As correlações encontradas entre os parâmetros radiculares e o $\mathrm{C}$ e Nmicrobiano não foram altas (abaixo de $r=0,60$ ). O DRC na cultura do milho apresentou correlação negativa com o C-microbiano $(r=-0,21 ; \mathrm{p}=0,01 ; \mathrm{n}=120)$ e positiva com Nmicrobiano $(r=0,27 ; \mathrm{p}=0,01 ; \mathrm{n}=120)$. A maior concentração de raízes de milho provavelmente alterou a relação $\mathrm{C}: \mathrm{N}$ microbiana por ter interferido na composição da comunidade microbiana. A maioria dos estudos em rizhotron ou in vitro demonstram um aumento significativo de bactérias ao redor das raízes em crescimento (Bolton Junior, 1993; Grayston et al., 1998) e de micorrizas (Andrade et al., 1998). Essas bactérias atraem predadores como protozoários e nematóides bacteriófagos. Os protozoários consomem as bactérias, mobilizando em torno de $1 / 3$ do $\mathrm{N}$ contido na biomassa 
bacteriana, que é liberado na forma de $\mathrm{NH}_{4}^{+}$e pode ser utilizado pelas raízes (Clarholm, 1989). Estudos específicos sobre a cadeia trófica e a mudança na composição da comunidade microbiana e da microfauna sob influência do sistema radicular durante o ciclo das leguminosas ou das gramíneas se fazem necessários para entende o diferentes fluxos de energia e de nutrientes no solo agrícola com alta intensificação tecnológica.

A DCR total (raízes finas + grossas) da soja não apresentou correlação significativa com o $\mathrm{C}$ ou o $\mathrm{N}$-microbianos. No entanto, a DCR das raízes finas da soja apresentou correlação somente com o N-microbiano ( $r=0,36 ; \mathrm{p}=0,001 ; \mathrm{n}=120)$, enquanto a DCR das raízes grossas da soja apresentou correlação significativa somente com o C-microbiano, deixando claro que as raízes finas são as responsáveis pelo maior efeito no $\mathrm{N}$-microbiano do que no $\mathrm{C}$-microbiano. As raízes finas são mais ativas fisiologicamente e tem maior capacidade de liberação de exsudatos em sua extremidade que as raízes grossas que exercem a função de sustentação. Na planta de trigo, o local da raiz onde há maior liberação de compostos orgânicos é o da alongação (Rovira, 1973; Campbell \& Greaves, 1990), porém as rizodeposições também ocorrem em outros locais (Bolton et al., 1993). Portanto, os resultados obtidos nesse trabalho apontam que a região onde ocorre maior concentração de raízes finas no solo há um direcionamento no efeito das raízes para o N-microbiano.

A DMSR do milho não apresentou correlação com o C-microbiano, mas sim com o $\mathrm{N}$-microbiano e a relação Nmic:Ntotal $(r=0,35$ e $r=0,40, \mathrm{p}=0,001, \mathrm{n}=120)$. A DMSR da soja apresentou fracas correlações com o $\mathrm{C}$ e $\mathrm{N}$-microbianos, $(r=0,30$ e $r=0,34$, $\mathrm{p}=0,001, \mathrm{n}=120$, respectivamente). Diante desses resultados, parece ter havido efeito da 
concentração de raízes ativas, mas somente sobre o $\mathrm{N}$-microbiano nas duas culturas analisadas e sobre o C-microbiano somente pelas raízes da soja.

$\mathrm{O}$ diâmetro das raízes das culturas não apresentou correlação com o $\mathrm{C}$ e $\mathrm{N}$ microbiano. Sendo o diâmetro uma variável resultante do comprimento, esperava-se que essa parâmetro expressasse uma relação imediata de causa/efeito da raízes sobre a comunidade microbiana. No entanto, ela talvez venha a ter importância futura para a comunidade microbiana, pois é através dos canais deixados pelas raízes que ocorrerão as trocas de gases e a infiltração da água no solo, auxiliando a expansão do sistema radicular da cultura subseqüente (Cannell, 1981; Kemper \& Derpsch, 1981).

As raízes da soja em decomposição ou com forma indefinida apresentaram uma correlação linear com o C-microbiano de $r=0,33$ ( $\mathrm{p}=0,01 ; \mathrm{n}=120)$, enquanto que na cultura do milho não foi significativa a correlação. No entanto, as raízes em decomposição apresentaram as maiores correlações com o N-microbiano. Na cultura do milho, a correlação foi de $r=0,53(\mathrm{p}=0,01 ; \mathrm{n}=120)$ e na cultura da soja foi de $r=0,60$ $(\mathrm{p}=0,01 ; \mathrm{n}=120)$. Pode-se dizer que esse característica do sistema radicular é o a que mais estimula o $\mathrm{N}$-microbiano. As raízes em decomposição, além de apresentarem a maior quantidade de $\mathrm{C}$ e $\mathrm{N}$ disponível para o crescimento microbiano, apresentaram ainda a menor relação $\mathrm{C}: \mathrm{N}$ (Tabela 10). Decorrente disto, o estímulo criado por essa característica sobre a biomassa microbiana pode, num primeiro momento, competir com a planta de milho pelo $\mathrm{N}$ mineral e imobilizá-lo, isso porque essas raízes apresentam uma relação C:N de aproximadamente 17-23:1 (Tabela 10). Ainda que isto se apresente como um substrato melhor balanceado que a palha. 
Diante dos resultados obtidos acima, pode se afirmar que local de maior densidade raízes finas ativas e de raízes em decomposição ou em forma indefinida nas duas culturas estão mais relacionados com o N-microbiano do que o C-microbiano, possivelmente devido ao aumento da comunidade bacteriana, decorrente da maior concentração de $\mathrm{C}$ e $\mathrm{N}$ de fácil assimilação, proporcionado por essas características radiculares.

\subsection{Conclusões}

- O cultivo da soja e do milho no sistema de plantio direto produzem efeitos diferenciados na biomassa microbiana. As raízes do milho estimulam o Cmicrobiano nas camadas mais profundas do solo, enquanto que as da soja atuam mais sobre o N-microbiano.

- As raízes finas e as raízes em decomposição ou de forma indefinida são os parâmetros que melhor expressam o efeito radicular, tanto da cultura do milho como da soja, sobre o N-microbiano do solo.

- $\quad \mathrm{O}$ milho, por ser uma planta $\mathrm{C}_{4}$, tem maior produção relativa de matéria seca radicular que a soja, porém a distribuição percentual de matéria seca no perfil do solo é semelhante entre as duas culturas em solo sob plantio direto.

- O cultivo de plantas com características morfológicas diferenciadas, como as de gramíneas $\left(\mathrm{C}_{4}\right)$ e leguminosas $\left(\mathrm{C}_{3}\right)$, beneficia o SPD por alternar efeitos sobre as características físicas (canais de drenagem, quantidade de matéria orgânica incorporada em profundidade) e biológicas do solo (disponibilidade de $\mathrm{N}$ lábil). 


\section{CONCLUSÕES GERAIS}

O sistema plantio direto (SPD) tem sido empregado pelos produtores rurais na região de Campos Gerais, Tibagi (PR) respeitando os três requisitos mínimos: não revolvimento do solo, rotação de culturas e uso de culturas de cobertura para formação de palhada, associada ao manejo integrado de pragas, doenças e plantas daninhas. Essas práticas têm efeito cumulativo no aumento da matéria orgânica do solo e, conseqüente, no aumento da biomassa microbiana. Dez anos de diferença no tempo de adoção do SPD (de 12 a 22 anos), levaram a um aumento da quantidade de C-microbiano na camada subsuperficial $10-20 \mathrm{~cm}$ e a um aumento da quantidade e constância do $\mathrm{N}$-microbiano na camada $0-20 \mathrm{~cm}$ do solo durante o processo de produção agrícola.

A textura do solo tem a capacidade de influenciar, a longo prazo, a quantidade de MOS e os teores de $\mathrm{C}$ e $\mathrm{N}$ microbianos. Entretanto, mesmo solos cultivados há mais de 10 anos no SPD, sob as mesmas condições climáticas, podem apresentar quantidades equivalentes de $\mathrm{C}$-microbiano na camada superficial $(0-5 \mathrm{~cm})$, especialmente quando pertencentes a classes texturais próximas. Nesse caso mudanças na estrutura física do solo (formação de agregados, capacidade de retenção de água) pode ter suplantado o efeito da textura.

Independente da textura, do tempo de adoção do SPD, da sequiência de culturas e das condições de campo, o C-microbiano apresenta melhor correlação do que o Nmicrobiano com as quantidades de N-mineral no solo, tanto na forma de nitrato com na de 
amônia, indicando ser este um parâmetro a ser considerado na modelagem da dinâmica do nitrogênio.

Não foi possível determinar o efeito da seqüência de culturas sobre a quantidade de C e N-microbianos tanto nas áreas diferindo no tempo de aloção do SPD como nas áreas diferindo na textura do solo. Fatores ambientais e analíticos não controláveis podem ter interferido nos resultados impossibilitando sua interpretação com respaldo estatístico. Observou-se, entretanto, que o sistema radicular de cada cultura teve efeito diferenciado sobre a biomassa microbiana. As raízes do milho promoveram aumento do C-microbiano nas camadas sub-superficiais do solo, enquanto que as da soja atuaram sobre o $\mathrm{N}$ microbiano na camada $020 \mathrm{~cm}$, região em que se concentram mais de $90 \%$ das raízes finas dessa cultura. Tanto na cultura do milho como na da soja são as raízes finas e as em decomposição ou de forma indefinida os principais parâmetros que determinam o aumento de N-microbiano no solo.

O emprego de plantas com características morfológicas diferenciadas, como o milho e a soja, beneficia a sustentabilidade do SPD do ponto de vista biológico por alternar efeitos sobre as características físicas (facilitar as trocas de gases, aumentar a entrada de matéria orgânica em profundidade) e bioquímicas do solo (disponibilidade de $\mathrm{C}$ e $\mathrm{N}$ lábil).

Por fim, concluímos que as práticas agrícolas causam impactos sobre a comunidade microbiana, sendo que a amplitude das alterações quantitativas de $\mathrm{C}$ e $\mathrm{N}$ imobilizados na BMS ocorrerá em função do tempo de adoção do SPD e da textura do solo. Esses fatores interferem na ciclagem de nutrientes e, portanto, devem ser considerados quando se pretende formular uma estratégia de otimização de aplicação de fertilizantes. 
ANEXOS 
Anexo A. Nitrato $\left(\mathrm{kg} . \mathrm{ha} \mathrm{a}^{-1}\right)$ nas 4 áreas sob sistema plantio direto, com duas sucessões de culturas em 9 épocas de amostragem

\begin{tabular}{|c|c|c|c|c|c|c|c|c|}
\hline \multirow[b]{2}{*}{$\begin{array}{l}\text { Profundidade } \\
(\mathrm{cm})\end{array}$} & \multicolumn{2}{|c|}{ PD12 TmeA ${ }^{T}$} & \multicolumn{2}{|c|}{ PD12 TA } & \multicolumn{2}{|c|}{ PD12 TmuA } & \multicolumn{2}{|c|}{ PD22 TA } \\
\hline & \multicolumn{7}{|c|}{ Setembro 2000} & Suc.B \\
\hline $0-2,5$ & $\mathrm{NC}$ & $\mathrm{NC}$ & 2,62 & 2,62 & 1,34 & 1,34 & 1,37 & 1,37 \\
\hline $2,5-5$ & $\mathrm{NC}$ & $\mathrm{NC}$ & 1,55 & 1,55 & 0,97 & 0,97 & 1,09 & 1,09 \\
\hline $5-10$ & $\mathrm{NC}$ & $\mathrm{NC}$ & 1,64 & 1,64 & 1,43 & 1,43 & 1,08 & 1,08 \\
\hline \multirow[t]{2}{*}{$10-20$} & $\mathrm{NC}$ & $\mathrm{NC}$ & 2,11 & 2,11 & 3,60 & 3,60 & 2,40 & 2,40 \\
\hline & \multicolumn{8}{|c|}{ Outubro 2000} \\
\hline $0-2,5$ & 1,68 & $\mathrm{NC}$ & 2,27 & $\mathrm{NC}$ & 10,68 & $\mathrm{NC}$ & 3,65 & $\mathrm{NC}$ \\
\hline $2,5-5$ & 1,36 & $\mathrm{NC}$ & 1,18 & $\mathrm{NC}$ & 11,09 & $\mathrm{NC}$ & 2,46 & $\mathrm{NC}$ \\
\hline $5-10$ & 4,07 & $\mathrm{NC}$ & 1,67 & $\mathrm{NC}$ & 11,54 & $\mathrm{NC}$ & 4,49 & $\mathrm{NC}$ \\
\hline \multirow[t]{2}{*}{$10-20$} & 9,07 & $\mathrm{NC}$ & 4,07 & $\mathrm{NC}$ & 26,43 & $\mathrm{NC}$ & 9,86 & $\mathrm{NC}$ \\
\hline & \multicolumn{8}{|c|}{ Novembro 2000} \\
\hline $0-2,5$ & 2,67 & 3,79 & 3,03 & 3,31 & 3,62 & 4,69 & 5,18 & 3,90 \\
\hline $2,5-5$ & 1,33 & 2,42 & 2,64 & 3,29 & 2,73 & 3,94 & 4,86 & 6,88 \\
\hline $5-10$ & 1,59 & 4,61 & 5,83 & 7,51 & 4,15 & 4,87 & 6,63 & 7,64 \\
\hline \multirow[t]{2}{*}{$10-20$} & 2,11 & 9,90 & 14,15 & 14,08 & 8,22 & 8,45 & 25,23 & 13,71 \\
\hline & \multicolumn{8}{|c|}{ Fevereiro 2001} \\
\hline $0-2,5$ & 1,67 & 3,15 & 1,87 & 1,81 & 1,05 & 1,53 & 5,35 & 2,62 \\
\hline $2,5-5$ & 1,30 & 1,70 & 1,37 & 1,28 & 0,94 & 0,87 & 3,70 & 2,10 \\
\hline $5-10$ & 1,39 & 1,54 & 1,53 & 1,45 & 1,87 & 1,03 & 3,02 & 2,28 \\
\hline \multirow[t]{2}{*}{$10-20$} & 1,38 & 1,40 & 2,47 & 1,34 & 3,37 & 1,71 & 2,79 & 1,58 \\
\hline & \multicolumn{8}{|c|}{ Maio 2001} \\
\hline $0-2,5$ & 1,53 & 3,49 & 2,16 & 3,78 & 3,90 & 7,87 & 2,68 & 2,97 \\
\hline $2,5-5$ & 1,12 & 1,40 & 1,73 & 2,09 & 2,67 & 5,08 & 2,47 & 2,10 \\
\hline $5-10$ & 1,54 & 1,51 & 2,66 & 3,27 & 4,86 & 7,58 & 4,30 & 3,81 \\
\hline \multirow[t]{2}{*}{$10-20$} & 3,73 & 3,15 & 6,11 & 6,71 & 11,36 & 13,74 & 9,76 & 9,65 \\
\hline & \multicolumn{8}{|c|}{ Junho 2001} \\
\hline $0-2,5$ & 1,09 & 2,25 & 1,63 & 1,68 & 3,30 & 4,28 & 1,84 & 2,09 \\
\hline $2,5-5$ & 2,17 & 2,23 & 2,35 & 1,70 & 2,76 & 3,58 & 2,84 & 3,12 \\
\hline $5-10$ & 5,94 & 4,55 & 5,59 & 5,04 & 4,15 & 5,28 & 6,76 & 6,52 \\
\hline \multirow[t]{2}{*}{$10-20$} & 13,31 & 10,37 & 12,35 & 13,40 & 6,75 & 9,83 & 15,45 & 16,50 \\
\hline & \multicolumn{8}{|c|}{ Agosto 2001} \\
\hline $0-2,5$ & 1,63 & 1,98 & 1,18 & 1,26 & 1,15 & 1,61 & 1,76 & 2,02 \\
\hline $2,5-5$ & 1,12 & 1,39 & 1,02 & 0,91 & 0,77 & 1,24 & 1,31 & 1,37 \\
\hline $5-10$ & 1,66 & 1,24 & 1,38 & 1,11 & 1,20 & 1,46 & 1,75 & 1,24 \\
\hline \multirow[t]{2}{*}{$10-20$} & 3,21 & 2,15 & 2,22 & 1,74 & 2,01 & 1,55 & 2,06 & 1,91 \\
\hline & \multicolumn{8}{|c|}{ Outubro 2001} \\
\hline $0-2,5$ & 3,18 & 3,58 & 3,80 & 3,13 & 3,81 & 4,46 & 4,83 & 5,09 \\
\hline $2,5-5$ & 2,37 & 2,36 & 3,23 & 2,52 & 2,78 & 2,94 & 3,92 & 4,41 \\
\hline $5-10$ & 2,84 & 2,63 & 2,86 & 4,43 & 3,03 & 3,69 & 3,44 & 4,48 \\
\hline \multirow[t]{2}{*}{$10-20$} & 3,15 & 5,52 & 4,49 & 8,79 & 3,29 & 4,25 & 2,75 & 3,88 \\
\hline & \multicolumn{8}{|c|}{ Fevereiro 2002} \\
\hline $0-2,5$ & $\mathrm{NC}$ & $\mathrm{NC}$ & 0,65 & 0,88 & 0,43 & 1,12 & 1,20 & 1,93 \\
\hline $2,5-5$ & $\mathrm{NC}$ & $\mathrm{NC}$ & 0,40 & 0,58 & 0,33 & 0,57 & 1,04 & 1,16 \\
\hline $5-10$ & $\mathrm{NC}$ & $\mathrm{NC}$ & 0,40 & 0,45 & 0,48 & 0,67 & 1,08 & 1,53 \\
\hline $10-20$ & $\mathrm{NC}$ & $\mathrm{NC}$ & 0,32 & 0,65 & 0,54 & 0,78 & 0,93 & 1,30 \\
\hline
\end{tabular}

${ }^{1}$ PD12 e PD22 = áreas com 12 e 22 anos sob sistema plantio direto, respectivamente; TA = solo com textura argilosa; TmuA = solo com textura muito argilosa $;$ TmeA = solo com textura média argilosa;

${ }^{2}$ Suc.A = Aveia-preta $/$ milho/trigo/soja; Suc.B = Aveia-preta/soja/trigo/soja;

${ }^{3}$ nd $=$ Não determinado 
Anexo B. Amônio $\left(\mathrm{kg} . \mathrm{ha}^{-1}\right)$ nas 4 áreas sob sistema plantio direto, com duas sucessões de culturas em 9 épocas de amostragem

\begin{tabular}{|c|c|c|c|c|c|c|c|c|}
\hline \multirow[b]{2}{*}{ Profundidade } & \multicolumn{2}{|c|}{$\mathrm{PD} 2 \mathrm{TmeA}^{\mathrm{T}}$} & \multicolumn{2}{|c|}{ PD12 TA } & \multicolumn{2}{|c|}{ PD12 TmuA } & \multicolumn{2}{|c|}{ PD22 TA } \\
\hline & Suc. $A^{2}$ & Suc.B & Suc.A & Suc.B & Suc.A & Suc.B & Suc.A & Suc.B \\
\hline$(\mathrm{cm})$ & \multicolumn{8}{|c|}{ Setembro 2000} \\
\hline $0-2,5$ & $\mathrm{NC}$ & $\mathrm{NC}$ & 0,64 & 0,64 & 0,57 & 0,57 & 3,03 & 3,03 \\
\hline $2,5-5$ & $\mathrm{NC}$ & $\mathrm{NC}$ & 0,33 & 0,33 & 0,40 & 0,40 & 1,87 & 1,87 \\
\hline $5-10$ & $\mathrm{NC}$ & $\mathrm{NC}$ & 0,99 & 0,99 & 0,86 & 0,86 & 1,95 & 1,95 \\
\hline \multirow[t]{2}{*}{$10-20$} & $\mathrm{NC}$ & $\mathrm{NC}$ & 2,55 & 2,55 & 1,81 & 1,81 & 2,38 & 2,38 \\
\hline & \multicolumn{8}{|c|}{ Outubro 2000} \\
\hline $0-2,5$ & 2,13 & $\mathrm{NC}$ & 3,28 & $\mathrm{NC}$ & 48,89 & $\mathrm{NC}$ & 4,21 & $\mathrm{NC}$ \\
\hline $2,5-5$ & 2,39 & $\mathrm{NC}$ & 1,59 & $\mathrm{NC}$ & 15,61 & $\mathrm{NC}$ & 2,65 & $\mathrm{NC}$ \\
\hline $5-10$ & 8,85 & $\mathrm{NC}$ & 3,20 & $\mathrm{NC}$ & 11,00 & $\mathrm{NC}$ & 13,63 & $\mathrm{NC}$ \\
\hline \multirow[t]{2}{*}{$10-20$} & 16,65 & $\mathrm{NC}$ & 5,97 & $\mathrm{NC}$ & 20,22 & $\mathrm{NC}$ & 26,09 & $\mathrm{NC}$ \\
\hline & \multicolumn{8}{|c|}{ Novembro 2000} \\
\hline $0-2,5$ & 2,82 & 1,07 & 1,45 & 1,04 & 1,23 & 4,38 & 1,95 & 1,66 \\
\hline $2,5-5$ & 0,92 & 0,70 & 0,86 & 0,80 & 0,73 & 1,70 & 1,18 & 1,37 \\
\hline $5-10$ & 1,39 & 1,74 & 1,15 & 1,20 & 2,37 & 2,08 & 1,54 & 1,73 \\
\hline \multirow[t]{2}{*}{$10-20$} & 2,51 & 2,82 & 3,52 & 2,20 & 4,26 & 3,76 & 1,28 & 3,40 \\
\hline & \multicolumn{8}{|c|}{ Fevereiro 2001} \\
\hline $0-2,5$ & 1,56 & 2,08 & 1,96 & 1,56 & 0,60 & 1,03 & 2,14 & 2,29 \\
\hline $2,5-5$ & 1,08 & 1,24 & 0,94 & 1,15 & 0,64 & 0,93 & 1,24 & 1,52 \\
\hline $5-10$ & 1,44 & 1,09 & 1,55 & 1,03 & 0,78 & 2,21 & 2,71 & 1,15 \\
\hline \multirow[t]{2}{*}{$10-20$} & 0,93 & 1,84 & 1,90 & 1,62 & 1,57 & 3,62 & 4,40 & 1,30 \\
\hline & \multicolumn{8}{|c|}{ Maio 2001} \\
\hline $0-2,5$ & 0,49 & 1,17 & 0,38 & 0,70 & 0,41 & 0,62 & 0,58 & 0,80 \\
\hline $2,5-5$ & 0,52 & 0,55 & 0,38 & 0,33 & 0,22 & 0,28 & 0,35 & 0,43 \\
\hline $5-10$ & 0,95 & 1,31 & 0,31 & 0,67 & 0,34 & 1,25 & 0,84 & 0,77 \\
\hline \multirow[t]{2}{*}{$10-20$} & 1,44 & 2,07 & 1,18 & 1,00 & 1,77 & 1,60 & 2,66 & 1,27 \\
\hline & \multicolumn{8}{|c|}{ Junho 2001} \\
\hline $0-2,5$ & 1,63 & 1,50 & 0,86 & 1,80 & 2,18 & 7,77 & 0,97 & 0,99 \\
\hline $2,5-5$ & 1,03 & 1,35 & 1,48 & 2,25 & 0,38 & 1,37 & 1,46 & 1,41 \\
\hline $5-10$ & 10,79 & 8,07 & 5,82 & 7,27 & 0,74 & 1,57 & 3,48 & 3,67 \\
\hline \multirow[t]{2}{*}{$10-20$} & 3,51 & 2,41 & 2,29 & 1,71 & 1,71 & 2,82 & 2,15 & 2,08 \\
\hline & \multicolumn{8}{|c|}{ Agosto 2001} \\
\hline $0-2,5$ & 1,25 & 2,49 & 0,92 & 1,12 & 1,21 & 1,75 & 1,32 & 1,71 \\
\hline $2,5-5$ & 1,93 & 0,90 & 0,69 & 0,62 & 0,68 & 1,34 & 0,94 & 0,83 \\
\hline $5-10$ & 0,87 & 1,26 & 0,98 & 1,07 & 1,35 & 1,07 & 0,99 & 1,04 \\
\hline \multirow{2}{*}{$10-20$} & 1,30 & 0,89 & 1,22 & 1,12 & 1,93 & 2,28 & 2,04 & 1,86 \\
\hline & \multicolumn{8}{|c|}{ Outubro 2001} \\
\hline $0-2,5$ & 1,75 & 1,05 & 1,58 & 1,62 & 0,91 & 0,87 & 2,63 & 2,22 \\
\hline $2,5-5$ & 0,74 & 0,45 & 0,91 & 0,81 & 0,42 & 0,52 & 1,45 & 1,16 \\
\hline $5-10$ & 0,84 & 2,45 & 1,46 & 1,74 & 0,85 & 0,64 & 0,67 & 0,84 \\
\hline \multirow[t]{2}{*}{$10-20$} & 1,46 & 2,14 & 2,60 & 2,69 & 1,83 & 1,78 & 1,09 & 1,09 \\
\hline & & & & Feve & 2002 & & & \\
\hline $0-2,5$ & $\mathrm{NC}$ & $\mathrm{NC}$ & 1,05 & 1,28 & 0,95 & 1,45 & 1,61 & 1,96 \\
\hline $2,5-5$ & $\mathrm{NC}$ & $\mathrm{NC}$ & 0,73 & 1,15 & 0,86 & 1,04 & 1,32 & 1,11 \\
\hline $5-10$ & $\mathrm{NC}$ & $\mathrm{NC}$ & 1,08 & 1,42 & 1,00 & 1,40 & 1,65 & 1,33 \\
\hline $10-20$ & NC & NC & 1,31 & 2,54 & 1,83 & 2,23 & 2,46 & 1,99 \\
\hline
\end{tabular}

${ }^{1} \mathrm{PD} 12$ e PD22 = áreas com 12 e 22 anos sob sistema plantio direto, respectivamente; TA = solo com textura argilosa; $\mathrm{TmuA}=$ solo com textura muito argilosa $;$ TmeA = solo com textura média argilosa;

${ }^{2}$ Suc.A = Aveia-preta $/$ milho/trigo/soja; Suc.B = Aveia-preta/soja/trigo/soja;

${ }^{3}$ nd $=$ Não determinado 
Anexo C. Nitrogênio mineral $\left(\mathrm{kg} . h \mathrm{~h}^{-1}\right)$ nas 4 áreas sob sistema plantio direto, com duas sucessões de culturas em 9 épocas de amostragem

\begin{tabular}{|c|c|c|c|c|c|c|c|c|}
\hline \multirow[b]{2}{*}{ Profundidade } & \multicolumn{2}{|c|}{ PD12 TmeA $^{1}$} & \multicolumn{2}{|c|}{ PD12 TA } & \multicolumn{2}{|c|}{ PD12 TmuA } & \multicolumn{2}{|c|}{ PD22 TA } \\
\hline & Suc. $A^{2}$ & Suc.B & Suc.A & Suc.B & Suc.A & Suc.B & Suc.A & Suc.B \\
\hline$(\mathrm{cm})$ & \multicolumn{8}{|c|}{ Setembro 2000} \\
\hline $0-2,5$ & $\mathrm{NC}$ & $\mathrm{NC}$ & 1,30 & 1,30 & 1,91 & 1,91 & 4,40 & 4,40 \\
\hline $2,5-5$ & $\mathrm{NC}$ & $\mathrm{NC}$ & 0,35 & 0,35 & 1,38 & 1,38 & 2,96 & 2,96 \\
\hline $5-10$ & $\mathrm{NC}$ & $\mathrm{NC}$ & 0,60 & 0,60 & 2,29 & 2,29 & 3,03 & 3,03 \\
\hline \multirow[t]{2}{*}{$10-20$} & $\mathrm{NC}$ & $\mathrm{NC}$ & 0,88 & 0,88 & 5,41 & 5,41 & 4,78 & 4,78 \\
\hline & \multicolumn{8}{|c|}{ Outubro 2000} \\
\hline $0-2,5$ & 3,82 & $\mathrm{NC}$ & 4,76 & $\mathrm{NC}$ & 59,56 & $\mathrm{NC}$ & 7,86 & $\mathrm{NC}$ \\
\hline $2,5-5$ & 3,75 & $\mathrm{NC}$ & 0,62 & $\mathrm{NC}$ & 26,71 & $\mathrm{NC}$ & 5,11 & $\mathrm{NC}$ \\
\hline $5-10$ & 12,92 & $\mathrm{NC}$ & 0,96 & $\mathrm{NC}$ & 22,54 & $\mathrm{NC}$ & 18,12 & $\mathrm{NC}$ \\
\hline $10-20$ & 25,72 & $\mathrm{NC}$ & 1,78 & $\mathrm{NC}$ & 46,65 & $\mathrm{NC}$ & 35,95 & $\mathrm{NC}$ \\
\hline \multicolumn{9}{|c|}{ Novembro 2000} \\
\hline $0-2,5$ & 5,50 & 4,86 & 3,99 & 3,06 & 4,85 & 9,07 & 7,13 & 5,56 \\
\hline $2,5-5$ & 2,25 & 3,12 & 0,45 & 0,46 & 3,45 & 5,65 & 6,04 & 8,26 \\
\hline $5-10$ & 2,98 & 6,35 & 0,87 & 0,86 & 6,52 & 6,95 & 8,16 & 9,37 \\
\hline $10-20$ & 4,62 & 12,71 & 1,66 & 1,67 & 12,48 & 12,21 & 26,50 & 17,11 \\
\hline \multicolumn{9}{|c|}{ Fevereiro 2001} \\
\hline $0-2,5$ & 3,23 & 5,23 & 1,48 & 1,29 & 1,65 & 2,56 & 7,49 & 4,91 \\
\hline $2,5-5$ & 2,38 & 2,93 & 0,43 & 0,34 & 1,57 & 1,80 & 4,94 & 3,61 \\
\hline $5-10$ & 2,83 & 2,64 & 0,68 & 0,60 & 2,65 & 3,24 & 5,73 & 3,44 \\
\hline $10-20$ & 2,32 & 3,24 & 0,97 & 0,87 & 4,94 & 5,33 & 7,19 & 2,88 \\
\hline \multicolumn{9}{|c|}{ Maio 2001} \\
\hline $0-2,5$ & 2,02 & 4,66 & 1,65 & 1,78 & 4,32 & 8,49 & 3,26 & 3,76 \\
\hline $2,5-5$ & 1,64 & 1,95 & 0,33 & 0,37 & 2,89 & 5,36 & 2,82 & 2,54 \\
\hline $5-10$ & 2,49 & 2,82 & 0,55 & 0,60 & 5,20 & 8,84 & 5,14 & 4,58 \\
\hline $10-20$ & 5,17 & 5,22 & 0,85 & 0,98 & 13,13 & 15,34 & 12,42 & 10,91 \\
\hline \multicolumn{9}{|c|}{ Junho 2001} \\
\hline $0-2,5$ & 2,71 & 3,75 & 3,09 & 3,37 & 5,48 & 12,05 & 2,80 & 3,08 \\
\hline $2,5-5$ & 3,20 & 3,57 & 0,27 & 0,33 & 3,14 & 4,95 & 4,30 & 4,53 \\
\hline $5-10$ & 16,73 & 12,61 & 0,61 & 0,79 & 4,89 & 6,84 & 10,24 & 10,19 \\
\hline $10-20$ & 16,82 & 12,78 & 1,74 & 1,94 & 8,46 & 12,65 & 17,60 & 18,58 \\
\hline \multicolumn{9}{|c|}{ Agosto 2001} \\
\hline $0-2,5$ & 2,88 & 4,47 & 1,07 & 0,51 & 2,35 & 3,37 & 3,07 & 3,72 \\
\hline $2,5-5$ & 3,06 & 2,29 & 0,37 & 0,75 & 1,45 & 2,58 & 2,25 & 2,19 \\
\hline $5-10$ & 2,53 & 2,50 & 0,55 & 0,90 & 2,55 & 2,53 & 2,74 & 2,28 \\
\hline $10-20$ & 4,51 & 3,03 & 0,54 & 0,20 & 3,95 & 3,82 & 4,10 & 3,76 \\
\hline \multicolumn{9}{|c|}{ Outubro 2001} \\
\hline $0-2,5$ & 4,93 & 4,64 & 1,08 & 1,29 & 4,72 & 5,32 & 7,46 & 7,31 \\
\hline $2,5-5$ & 3,11 & 2,81 & 1,71 & 1,83 & 3,20 & 3,47 & 5,37 & 5,56 \\
\hline $5-10$ & 3,68 & 5,08 & 2,19 & 2,20 & 3,88 & 4,33 & 4,11 & 5,33 \\
\hline $10-20$ & 4,61 & 7,66 & 0,50 & 0,48 & 5,12 & 6,04 & 3,84 & 4,97 \\
\hline \multicolumn{9}{|c|}{ Fevereiro 2002} \\
\hline $0-2,5$ & $\mathrm{NC}$ & $\mathrm{NC}$ & 0,90 & 0,78 & 1,38 & 2,57 & 2,81 & 3,89 \\
\hline $2,5-5$ & $\mathrm{NC}$ & $\mathrm{NC}$ & 0,22 & 0,23 & 1,19 & 1,61 & 2,36 & 2,27 \\
\hline $5-10$ & $\mathrm{NC}$ & $\mathrm{NC}$ & 0,35 & 0,38 & 1,49 & 2,07 & 2,73 & 2,86 \\
\hline $10-20$ & $\mathrm{NC}$ & $\mathrm{NC}$ & 0,50 & 0,56 & 2,37 & 3,02 & 3,39 & 3,29 \\
\hline
\end{tabular}

${ }^{1} \mathrm{PD} 12$ e PD22 = áreas com 12 e 22 anos sob sistema plantio direto, respectivamente; $\mathrm{TA}$ = solo com textura argilosa; TmuA = solo com textura muito argilosa $\mathrm{e} ; \mathrm{Tme} \mathrm{A}=$ solo com textura média argilosa;

${ }^{2}$ Suc.A = Aveia-preta $/$ milho/trigo/soja; Suc.B = Aveia-preta/soja/trigo/soja;

${ }^{3}$ nd $=$ Não determinado 


\section{REFERÊNCIA BIBLIOGRAFICAS}

AMADO, T.J.C.; FERNANDEZ, S.B.; MIELNICZUK, J. Nitrogen availability as affected by ten years of cover crop and tillage systems in southern Brazil. Journal Soil and Water Conservation, v.53, p.268-271, 1998.

AMATO, M.; LADD, J.N. Decomposition of ${ }^{14} \mathrm{C}$-labelled glucose and legume material in soil: Properties influencing the accumulation of organic residue $\mathrm{C}$ and microbial biomass C. Soil and Biology Biochemistry, v.24, p.455-464, 1992.

AMÉZKETA, E. Soil aggregate stability: A review. Journal of Sustainable Agriculture. v.14, p.83-151, 1999.

ANDRADE, G.; LINDERMAN, R.G.; BETHLENFALVAY, G.J. Bacterial associations with the mycorrhizosphere and hyphosphere of the arbuscular mycorrhizal fungus Glomus mosseae. Plant and Soil, v.202, p.79-87, 1998.

ARVIDSSON, J. Influence of soil texture and organic matter content on bulk density, air content, compression index and crop yield in field and laboratory compression experiments. Soil and Tillage Research v.49 p.159-170, 1998.

AYRES, W. A.; THORNTON, R.H. Exudation of amino acids by intact and damaged roots of wheat and peas. Plant and Soil, v.28 p.193-207, 1968. 
BALOTA, E.L; COLOZZI-FILHO, A.; ANDRADE, D.S.; HUNGRIA, M. Biomassa microbiana e sua atividade em solos sob diferentes sistemas de preparo e sucessão de culturas. Revista Brasileira Ciência do Solo, v.22, p.641-649, 1998.

BALOTA, E.L.; COLOZZI-FILHO, A.; ANDRADE, D.S.; DICK, R.P. Microbial biomass in soils under different tillage and crop rotation systems. Biology $\&$ Fertility of Soil, v.38, p.15-20, 2003.

BARBER, S.A. Soil nutrient bioavailability - a mechanistic approach. New York: John Wiley, 1995. 414p.

BAYER, C.; BELTOL, I. Caracteristicas químicas de um Cambissolo húmico afetado por sistema de preparo, com ênfase à matéria orgânica. Revista Brasileira Ciência do Solo, v.23, p.687-694, 1999.

BEARE, M.H.; CABRERA, M.L.; HENDRIX, P.F.; COLEMAN, D.C. Aggregateprotected and unprotected organic matter pools in conventional and no-tillage soils. Soil Science Society of America Journal, v.58, p.787-795, 1994.

BILLES, G.; BOTTNER, P. Living roots effects on ${ }^{14} \mathrm{C}$ carbon isotope-labelled root litter decomposition. Plant and Soil, v.62, p.193-208, 1981.

BLAKE, G.R.; HARTGE, K.H. Bulk density. In: KLUTE, A. (Ed.). Methods of soil analysis. 2.ed. pt 1: Physical and mineralogical methods. Madison: ASA, 1986. p.363-376. (Agronomy, 9).

BLEVINS, R.L.; THOMAS, G.W.; CORNELIUS, P.L. Influence of no-tillage and nitrogen fertilization on certain soil proportions affecter 5 years of continuous corn. Agronomy Journal, v.69, p.383-386, 1977. 
BOER, W. de.; KOWALCHUK, G.A. Nitrification in acid soils: micro-organisms and mechanisms. Soil Biology and Biochemistry, v.17, p.853-866, 2001.

BOHM, W. Methods of studying root systems. New York: Springer-Verlag, 1979. 189 p.

BOLTON JUNIOR, H.; FREDRICKSON, J.K.; ELLIOTT, L.F. Microbial ecology of the rhizosphere. In: METTING JUNIOR, F.B. (Ed.). Soil microbial ecology: applications in agricultural ad environment management. New York: Marcel Dekker, 1993. cap.2, p. 27-63.

BORGES, G.O. Resumo histórico do plantio direto no Brasil. In: EMBRAPA-CNPT, FUNDACEP-FECOTRIGO, FUNDAÇÃO ABC. Plantio Direto no Brasil. Passo Fundo:Editora Aldeia Norte ,1993. p.13-17

BORTOLUZZI, E.C.; ELTZ, F.L.F. Efeito do manejo mecânico da palhada de aveia preta sobre a cobertura, temperatura e teor de água no solo, e emergência da soja em sistema plantio direto. Revista Brasileira Ciência do Solo, v.24, p.449-547, 2000.

BROOKES, P.C.; LANDMAN, A.; PRUDEN, G.; JENKINSON, D.S. Chloroform fumigation and the release of soil nitrogen. Soil Biology and Biochemistry, v.17, p.837-847, 1985.

BRUCE, R.R.; LANGDALE, G.W.; DILLARD, A.L. Tillage and crop rotation effect on characteristic of a sandy surface soil. Soil Science Society America Journal, v.54, p.1744-1747, 1992.

CAMARGO, O.A. de; MONIZ, A.C.; JORGE, J.A.; VALADARES, J.M.A.S. Métodos de análises química, mineralógica e física do Instituto Agronômico. Campinas: Instituto Agronômico de Campinas, 1986. 94p. (IAC. Boletim Técnico, 106). 
CAMBARDELLA, C.A.; ELLIOT, E.T. Particulate soil organic matter changes a grassland cultivation sequence. Soil Science Society of America Journal, v.56, p.777-783, 1992.

CAMPBELL, R.; GREAVES, M.P. Anatomy and Community structure of the rhizosphere. In: LYNCH, J.M. The rhizosphere. Chichester, England; New York: John Wiley Ltda, 1990. cap.2, p.11-34.

CANNELL, R.Q. Soil cultural practices related to root development. In: RUSSELL, R.S.; IGUE, K.; MEHTA, Y.R. (Ed). The soil/root system in relation to Brazilian agriculture. Londrina: Fundação Instituto Agronômico do Paraná, 1981. p.61-80.

CARTER, M.R. Influence of reduced tillage systems on organic matter, microbial biomass, macro-aggregate distribution and structural stability of surface soil in a humid climate. Soil \& Tillage Research, v.23, p.361-372, 1992.

CARTER, M.R.; RENNIE, D.A. Changes in soil quality under zero tillage farming systems: distribution of microbial biomass and mineralizable $\mathrm{C}$ and $\mathrm{N}$ potentials. Canadian Journal of Soil Science, v.62, p.587-597, 1982.

CARVALHO, Y. Densidade e atividade dos microrganismos do solo em plantio direto e convencional, na região de Carambeí - PR. Curitiba, 1997. 84p. Dissertação (Mestrado) - Universidade Federal do Paraná.

CATTELAN, A.J.; VIDOR, C. Flutuações na biomassa, atividade e população microbiana do solo, em função de variações ambientais. Revista Brasileira Ciência do Solo, v.14, p.133-142, 1990. 
CATTELAN, A. J.; GAUDÊNCIO, C. A.; SILVA, T. A. Sistemas de rotação de culturas em plantio direto e os microrganismos do solo, na cultura da soja em Londrina. Revista Brasileira Ciência do Solo, v. 21, p.293-301, 1997.

CHEN, J.; STARK, J.M. Plant species effects and carbon and nitrogen cycling in sagebrush - crested wheatgrass soil. Soil Biology and Biochemistry, v.32, p.47-53, 2000.

CHENG, W.; COLEMAN, D.C. Effect of living roots on soil organic matter decomposition. Soil Biology and Biochemistry, v.22, p.781-788, 1990.

CLARHOLM, M Effects of plant-bacteriaramoebal interactions on plant uptake of nitrogen under field conditions. Biology and Fertility of Soils, v.8, p.373-378, 1989.

CONSTANTINI, A; COSENTINO, D.; SEGAT, A., Influence of tillage systems on biological properties of a typic argiudoll soil under continuous maize in central Argentina. Soil \& Tillage Research, v.38, p.265-271, 1996.

CRESTANA, S.; GUIMARÃES, M.F.; JORG, L.A.C.; RALISH, R.; TOZZI, C.L.; TORRE, A.; VAZ, C.M.P. Avaliação da distribuição de raízes no solo auxiliada por processamento de imagens digitais. Revista Brasileira de Ciência do Solo, v. 18, n.3, p. 365-371, 1994.

CUENCA, G.; ARANGUREN, J.; HERRARA, R. Root growth and litter decomposition in a coffee plantation under shade trees. Plant and Soil, v.71, p.477-486, 1983.

CURL, E.A.; TRUELOVE, B. The Rhizosphere. New York: Springer-Verlag, 1986. $288 \mathrm{p}$.

DALAL, R.C. Soil microbial biomass - What do the numbers really mean? Australian Journal of Experimental Agriculture, v.38, p.649-665, 1998. 
DENG, S.P.; MOORE, J.M.; TABATABAI, M.A. Characterization of active nitrogen pools in soils under different cropping systems. Biology and Fertility of Soils, v.32, p.302-309, 2002.

DORAM, J.W. Soil microbial and biochemical changes associated with reduced tillage. Soil Science Society of America Journal, v.44, p.765-771, 1980.

DICK, W.A.; McCOY, E.L.; EDWARDS, W.M.; LAL, R. Continuos application of notillage to Ohio soils. Agronomy Journal, v.83, p.65-73, 1991.

DUXBURY, J.M.; LAUREN, J.G.; FRUCI, J.R. Measurement of the biologically-active soil-nitrogen fraction by a $\mathrm{N}^{15}$ technique. Agriculture Ecosystems and Environment, v.34, p.121-129, 1991.

ELLIOTT, E.T.; COLEMAN, D.C. Let the soil work for us. Ecological Bulletin, v.39, p. 23-32, 1988.

FANTE JÚNIOR, L. Sistema radicular da aveia forrageira avaliada por diferentes métodos, incluindo processamento de imagens digitais. Piracicaba, 1997. 119p. Tese (Doutorado) - Centro de Energia Nuclear na Agricultura, Universidade de São Paulo.

FEBRAPDP - Federação Brasileira de Plantio Direto na Palha. (2003) http://www.febrapdp.org.br./area_PD_Brasil_(15 jan. 2002).

FEHR, W.R.; CAVINESS, C.E.; BURMOOD, D.T.; PENNINGTON, J.S. Stage of development description for soybean (Glycine $\max$ (L.) Merrill). Crop Science, v.11, p.929-931, 1971.

FOLLETT, R.F.; SCHIMEL, D.S. Effect of tillage practices on microbial biomass dynamics. Soil Society of America Journal, v.53, p.1091-1096, 1986. 
GALE, W.J.; CAMBARDELLA, C.A. Carbon dynamics of surface residue-and rootderived organic matter under simulated no-till. Soil Science of America Journal, v.64, p.190-195, 2000.

GRAYSTON, S.J; WANG, S.; CAMPBELL, C.D.; EDWARDS, A.C. Selective influence of plant species on microbial diversity in the rhizosphere. Soil Biology $\&$ Biochemistry, v.30, n.3, p.369-378, 1998.

GRIFFIN, G.J.; HALE, M.G.; SHAY, F.J. Nature and quantity of sloughed organic matter produced by roots of axenic peanut plants. Soil Biology and Biochemistry, v.8, n.1, p.123-129, 1976.

HASSINK, J.; BOUWMAN, L.A.; ZWART, K.B.; BLOEM, J.; BRUSSAARD, L. Relationships between soil texture, physical protection of organic matter, soil biota, and C and N mineralization in grassland soils. Geoderma, v.57, p.105-128, 1993.

HAVLIN, J.L.; KISSEL, D.E.; MADDUX, L.E.; CLAASSEN, M.M.; LONG, J.H. Crop rotation and tillage effects on soil organic carbon and nitrogen. Soil Science Society of America Journal, v.54, p.448-452, 1990.

HAYNES, R.J. Size and activity of the soil microbial biomass under grass and arable management. Biology and Fertility of Soils, v.30, p.210-216, 1999.

HERMAN, W.A.; McGILL, W.B., DORMAAR, J.F. Effects of initial chemical composition decomposition of roots of three grass species. Canadian Journal of Soil Science, v.57, p.205-215, 1977.

HUNT, H.W.; COLEMAN, D.C.; INGHAM, ELLIOTT, E.T.; MOORE, J.C.; ROSE, S.L.; REID, C.P.P.; MORLEY, C.R. The detrital food web in a shortgrass prairie. Biology and Fertility of Soils, v.3, p.57-68, 1987. 
INGRAM，E.R.; TROFYMOW，J.A.; AMES，R.N. HUNT，H.W.; MORLEY，C.R.; MOORE, J.C.; COLEMAN, D.C. Thophic interactions and nitrogenic cycling in a semi-arid grassland soil. II. System responses to removal of different groups of soil microbes or fauna. Journal Applied Ecology, v.23, p.615-630, 1986.

INSTITUTO AGRONÔMICO DO PARANÁ. Cartas climatologicas do Estado do Paraná - 1994. Londrina: IAPAR, 1994. 49p. (IAPAR. Documento, 18).

JENKINSON, DS. Studies on the decomposition of plant material in soil. V. The effects of plant cover and soil type on the loss of carbon from ${ }^{14} \mathrm{C}$ labeled ryegrass decomposing under field conditions. Journal of Soil Science, v.28, p.424-434, 1977.

JENSEN, E.S. Rhizodeposition of $\mathrm{N}$ by pea and barley and its effect on soil $\mathrm{N}$ dynamics. Soil Biology \& Biochemistry, v.28, p.65-71, 1996.

JOERGENSEN, R.G.; BROOKES, P.C Ninhydrin-reative nitrogen measurements of microbial biomass in 0,5 $\mathrm{M} \mathrm{K}_{2} \mathrm{SO}_{4}$ soil extracts. Soil Biology and Biochemistry, v.22, p.1023-1027, 1990.

JONES, D.L. Amino acid biodegradation and its potential effects on organic nitrogen capture by plants. Soil Biology and Biochemistry, v.31, p.613-622, 1999.

JORGE, L.A.C.; RESENDE, P.C.S.; POSADAS DURAND, A.; FREITAS JUNIOR, E.; CRESTANA, S. Comparação de técnicas de análise de imagens digitais na determinação do comprimento de raízes. In: REUNIÃO BRASILEIRA DE MANEJO E CONSERVAÇÃO DO SOLO E DA ÁGUA, 10., Florianópolis, 1994. Resumos. Florianópolis: SBCS, 1994. p. 314-315.

JUMA, N.G. Interrelationships between soil struture/texture, soil biota/soil organic matter and crop production. Geoderma, v.57, p.3-30, 1993. 
KANDELER, E.; TSCHERKO, D.; SPIEGEL, H. Long-term monitoring of microbial biomass, $\mathrm{N}$ mineralisation and enzyme activities of a Chernozem under different tillage management, Biology \& Fertility of Soil, v.38, p.343-351, 1999

KEMPER, B.; DESPSCH, R. Soil compaction and root growth in Paraná. In: RUSSELL, R.S.; IGUE, K.; MEHTA, Y.R. (Ed). The soil/root system in relation to Brazilian agriculture. Londrina: Fundação Instituto Agronômico do Paraná, 1981. p.81-100.

KUIKMAN, P.J.; VEEN, J.A.van. The impact of protozoa on the availability of bacterial nitrogen to plants. Biology and Fertility Soil, v.8, p.13-18, 1989.

LADD, J.N.; FOSTER, R.C.; SKJEMSTAD, J.O. Soil struture: carbon and nitrogen metabolism. Geodema, v.56, p.401-434, 1993.

LADD, J.N.; JOCTEUR-MONROZIER, L.; AMATO, M. Carbon turnover and nitrogen transformations in an alfisol and vertisol amended with $\left[\mathrm{U}^{14} \mathrm{C}\right]$ glucose and $\left[{ }^{15} \mathrm{~N}\right]$ ammonium sulfate. Soil Biology and Biochemistry, v.24, p.359-371, 1992.

LIMA, V.C.; LIMA, J.M.J.C.; EDUARDO, B,J.F.P.; CERRI, C.C. Conteúdo de carbono e biomassa microbiana em agrossistemas: Comparação entre métodos de preparo de solo. Agrárias, v.13, p.297-302, 1994.

LUNDQUIST, E.J.; JACKSON, L.E.; SCOW, K.M. Changes in microbial biomass and community composition, and soil carbon and nitrogen pools after incorporation of rye into three California agriculture soils. Soil Biology and Biochemistry, v.31, p.221-236, 1999. 
LYNCH, J.M. Limits of microbial growths in soil. Journal General Microbiology, v.128, p.405-410, 1982.

LYNCH, J.M.; PANTING, L.M. Cultivation and the soil biomass. Soil Biology and Biochemistry, v.12, p. 29-33, 1980.

MAACK, R. Geografia física do Paraná: classificação do clima do Estado do Paraná. 2.ed. Rio de Janeiro: Livraria José Olimpio, 1981. 442p.

MARSCHNER, H. Mineral nutrition of higher plant. New York: Academic Press, 1995. 889p.

MARUMOTO, T. Mineralization of $\mathrm{C}$ and $\mathrm{N}$ from microbial biomass in Paddy soil. Plant and Soil, v.76, p.165-173, 1984.

McCARTY, G.W.; MEISINGER, J.J.; JENNISKENS, F.M.M. Relationships between total- $\mathrm{N}$, biomass- $\mathrm{N}$ and active- $\mathrm{N}$ in soil under different tillage and $\mathrm{N}$ fertilizer treatments. Soil Biology and Biochemistry, v.27, p.1245-1250, 1995.

McCARTY, G.W.; LYSSENKO, N.N.; STARR, J.L. Short-term changes in soil carbon and nitrogen pools during tillage management transition. Soil Science Society of America Journal, v.62, p.1564-1571, 1998.

McGILL, W.B.; DORMAAR, J.E.; REINL-DWYER, E. New perspective on soil organic matter quality, quantity and dynamics on the Canadian prairies. In: ANNUAL MEENTING CONSERVATION SOIL SCIENCE SOCIETY, 34; proceedings. Calgary, 1988. Land and degradation and conservation tillage Calgary: CSSS, AIC, 1988. p.30-38. 
MELLO IVO, W.M.P. de; MIELNICZUK, J. Influência da estrutura do solo na distribuição e na morfologia do sistema radicular do milho sob três métodos. Revista brasileira de Ciência do Solo, v.23, p.135-143, 1999.

MENDES, I.; CARNEIRO, R.; CARVALHO, A.; VIVALDI, L.; VARGAS, M. Biomassa $\mathrm{C}$ e atividade microbiana em solos de cerrado sob plantio direto e plantio convencional. In: REUNIÃO BRASILEIRA DE MANEJO E CONSERVAÇÃO DO SOLO E DA ÁGUA, 13., Ilhéus, 2000. Resumos. Ilhéus: SBCS, 2000. p.44.

MERCKX, R.; HARTOG, A. den; VEEN, J.A. van. Turnover of root-derived material and related microbial biomass and formation in soil of different texture. Soil Biology and Biochemistry, v.17, p.565-569, 1985.

MERCKX, R.; VANGINKEL, J.; SINNAEVE, J.; CREMERS, A. Plant-induced changes in the rhizosphere of maize and wheat. I. Production and turnover of rootderived material in the rhizosphere of maize and wheat. Plant and Soil, v.96. p.8594, 1986.

MILLER, H.J.; HENKEN, G.; VEEN, J.A. van. Variation and composition of bacterial populations in rhizosphere of maize, wheat and grass cultivars. Canadian Journal of Microbiology, v. 16, p.656-660, 1989.

MOORE, J.C.; RUITER, P.C. de. Temperal and spatial heterogeneity of trophic interactions with below-ground food webs. Agriculture Ecosystem and Environmental, v.34, p.371-397, 1991.

MOREIRA, F.M.S.; SIQUEIRA, J.O. Microbiologia e bioquímica do Solo. Lavras: Editora UFLA, 2002. cap.3, p.81-152: Ecologia do solo. 
MUELLER, B.R.; BEARE, M.R.; CROSSLEY JUNIOR, D.A. Soil mites in detrital food webs of conventional and no-tillage agroecosystems. Pedobiologia, v.34, p.389-401, 1990.

NEAL, J.L.; LARSON, R.I.; ATKINSON, T.G. Changes in rhizosphere populations of selected physiological groups of bacteria related to substitution of specific pairs of chromosomes in spring wheat. Plant and Soil, v.39, p.209-212, 1973.

NEERGAARD, A. de; MAGID, J. Influence of the rhizosphere on microbial biomass and recently formed organic matter. European Journal of Soil Science, v.52, p.377-384, 2001.

NOMMIK, H.; VAHTRAS, K. Retention and fixation of ammonium and ammonia in soils. In: STEVENSON, F.J. (Ed). Nitrogen in agricultural soils. 2.ed. Madison: ASA, CSSA,SSSA, 1985. p123 - 227. (Agronomy, 22)

O'SULLIVAN, M.F. Uniaxial compaction effects on soil physical properties in relation to soil type and cultivation. Soil and Tillage Research, v.24, p.257-269, 1992.

OMAY, A.B.; RICE, C.W.; MADDUX, L.D.; GORDON, W.B. Changes in soil microbial and chemical properties under long-term crop rotation and fertilization. Soil Science Society of America Journal, v.61, p.1672-1678, 1997.

PARKINSON, D.; PAUL, E.A. Microbial biomass. In: PAGE, A.L.; MILLER, R.H. KEENEY, D.R. (Ed). Methods of soil analysis. Chemical and microbiological properties, Madison: SSSA, 1982. pt 2. p.821-829. 
PARMELEE, R.W.; BEARE, M.H.; CHENG, W.; HENDRIX, P.F.; RIDER, S.J.; CROSSLEY JUNIOR, D.A.; COLEMAN, D.C.; Earthworms and enchytraeids in conventional and no-tillage agroecosystems: a biocide approach at assess their role in organic matter breakdown. Biology and Fertility Soil, v.10, p.1-10, 1990.

PATRA, D. D.; BROOKES, P. C.; COLEMAN, K.; JENKINSON, D. S. Seasonal changes of soil microbial in an arable and grassland soil which have been under uniform management for many years. Soil Biology and Biochemistry, v.22, p.739$742,1990$.

PAUL, E.A.; VORONEY, R.P. Field interpretation of microbial biomass activity measurements. In: KLUG, M.J.; REDDY, C.A. (Ed.). Current perspectives in microbial ecology. Washington: American Society for Microbiology, 1983. p.123131.

POWLSON, D.S.; BROOKES, P.C.; CHRISTENSEN, B.T. Measurement of soil microbial biomass provides and early indication of changes in total soil organic matter due to straw incorporation. Soil Biology and Biochemistry, v.19, p.159-164, 1987.

PURI, G.; ASHMAN, M.R. Relationship between soil microbial biomass and gross $\mathrm{N}$ mineralisation. Soil Biology and Biochemistry, v.30, p.251-256, 1998.

QIAN, J.H.; DORAN, J.W.; WALTERS, D.T. Maize plant contributions to root zone available carbon and microbial transformations of nitrogen. Soil Biology and Biochemistry, v.29, p.1451-1462, 1997. 
RAHN, C.R.; LILLYWHITE, R.D. A study of the quality factors affecting the short term decomposition of field vegetable residues. Journal of the Science of Food and Agriculture, v.82, p.19-26, 2001.

RHOTON, F.E. Influence of time on soil response to no-till practices. Soil Science Society of America Journal, v.64, p.700-709, 2000.

ROVIRA, A.D. Root excretions in relation to the rhizosphere effect: IV. Influence of plant species, age of plant, light, temperature, and calcium nutrition on exudation. Plant and Soil, v.36, p.53-64, 1959.

ROVIRA, A.D. Biology of the soil-root interface. In: HARLEY, J.L.; RUSSELL, R.S. (Ed). The soil root interface. New York: Academic Press, 1979. p.145-160.

RUZICKA, J.; HANSEN, E.H. Flow Injection analysis. New York: WilleyInterscience, 1981. 271p.

SÁ, J.C.M. Manejo de nitrogênio na cultura de milho no sistema plantio direto. Passo Fundo: Alteia Norte Editora, 1996. 23p.

SÁ, J.C.M.; CERRI, C.C.; DICK, W.A. LAL, R.; VENZKE FILHO, S.P.; PICCOLO, M.C.; FEIGL, B.E. Organic matter dynamic and carbon sequestration rates for a tillage chronosequences in a Brazilian Oxisol. Soil Science Society America Journal, v.65, p.1486-1499, 2001.

SÁ, J.C.M. Dinâmica da matéria orgânica do solo em sistemas de manejo convencional e plantio direto. Piracicaba, 2001. 141p. Tese (Doutorado) - Escola Superior de Agricultura “Luiz de Queiroz”, Universidade de São Paulo 
SÁ, M.F.M. Abordagem quantitativa na predição espacial de atributos do solo e geração de zonas de manejo agrícola. Piracicaba, 2001. 117p. Tese (Doutorado) - Escola Superior de Agricultura “Luiz de Queiroz”, Universidade de São Paulo.

SALINAS-GARCÍA，J.R.; VELÁZQUEZ-GARCÍA，J.de J.; GALLARDO-VALDEZ, M.; MEDEROS-DÍAZ, P.; CABALLERO-HERNÁNDEZ, F.; TAPIA-VARGAS, L.M.; ROSALES-ROBLES, E. Tillage effects on microbial biomass and nutrient distribution in soil under rain-fed corn production in central - western Mexico. Soil and Tillage Research, v.24, p.143-152, 2002.

SAS Institute. SAS/STAT guide for personal computers : version 6. Cary:SAS Intitute, 1987. 1v.

SCHURMANN, J.J.; GOEDEWAAGEN, M.A.J. Methods for the examination of root systems and roots . 2.ed. Wageningen: Pudoc, 1971. 86p.

SHIERLAW, J.; ALSTON, A.M. Effect of soil compaction on root growth and uptake of phosphorus. Plant and Soil, v.77, p.15-28, 1984.

SILVA FILHO, G.N.; VIDOR, C., As práticas de manejo de solo na população microbiana. Revista Brasileira Ciência do Solo, v. 8, p.291-296, 1984.

SIQUEIRA NETO, M. Estoque de carbono e nitrogênio do solo e emissões de gases do efeito estufa no sistema plantio direto em Tibagi (PR). Piracicaba, 2003. 91p. Dissertação (Mestrado) - Centro de Energia Nuclear na Agricultura, Universidade de São Paulo.

SIX, J.; ELLIOTT, E.T.; PAUSTIAN, K. Aggregate and soil organic matter dynamics under conventional and no-tillage systems. Soil Science Society of America Journal, v.63, p.1350-1358, 1999. 
SIX, J.; FELLER, C.; DENEF, K.; OGLE, M.S.; SÁ, J.C.M.; ALBRECHT, A. Soil organic matter, biota and aggregation in temperate and tropical soils - effects of notillage. Agronomie, v.22, p.755-775, 2002.

SMITH, J.L. Cycling of nitrogen through microbial activity. In: HATFIELD, J.L.; STEWART, B.A. Soil biology: effects on soil quality. Boca Raton: CRC Press, 1994. p.91-120. (Advances in Soil Science).

SNEH GOYAL, M.M.M.; HOODA, I.S.; SINGH, R. Organic matter-microbial biomass relationships in field experiments under tropical conditions: effects of inorganic fertilization and organic amendments. Soil Biology and Biochemistry, v.24, p.10811084, 1992.

SOUZA, W. J. O.; MELO, W. J. Teores de nitrogênio no solo e nas frações da matéria orgânica sob diferentes sistemas de produção de milho. Revista Brasileira Ciência do Solo, v.24, p.885-896, 2000.

SPARLING, G.P. Ratio of microbial biomass carbon to soil organic carbon as a sensitive indicator of change in soil organic matter. Australian Journal Soil Research, v.30, p.195-207, 1992.

SPARLING, G.P.; WEST, A.W. A direct extraction method to estimate soil microbial C: calibration in situ using microbial respiration and ${ }^{14} \mathrm{C}$ labeled sells. Soil Biology and Biochemistry, v.20, p.337-343, 1988.

SPARLING, G.P.; ROSS, D.J. Biochemical methods to estimate soil microbial biomass: current developments and applications. In: MULONGOY, K.; MERCKX, R. (Ed). Soil organic matter dynamics and sustainability of tropical agriculture. Chichester: Wiley, 1993. p. 21-37. 
SPARLING, G.P.; ZHU, C. Evaluation and calibration of biochemical methods to measure microbial biomass $\mathrm{C}$ and $\mathrm{N}$ in soils from western Australia. Soil Biology and Biochemistry, v.25, p.1793-1801, 1993.

SPARLING, G.P.; CHESHIRE, M.V.; MUNDIE, C.M. Effect of barley plants on the decomposition of ${ }^{14} \mathrm{C}$-labelled soil organic matter. Soil Science Society America Journal, v.33, p.89-100, 1982.

SPARLING, G.P.; GRUPTA, V.V.S.R.; ZHU, C. Release of ninhydrin-reactive compounds during fumigation of soil to estimate microbial C and N. Soil Biology and Biochemistry, v.25, p.1803-1805, 1993.

STAAF, H. Litter decomposition in beech forest: Effect of excluding tree roots. Biology and Fertility of Soils, v.6, p.302-305, 1988.

STALEY, T.E.; EDWARDS, C.L.; SCOTT, C.L.; OWENS, L.B. Soil microbial biomass and organic component alterations in a no-tillage chronosequence. Soil Science Society America Journal, v.52, p.998-1000, 1988.

STRUWE, S.; KJØLLER, A. Changes in population structure during decomposition. In: JENSEN, V.; KJØLLER, A.; SORENSEN, L.H. (Ed). SYMPOSIUM OF THE FEDERATION OF EUROPEAN MICROBIOLOGICAL SOCIETIES, Copenhagen, 1985. Microbial communities in soil: proceedings. New York: Elsevier, 1985. p.149- 162 .

TISDALL, J.M.; OADES, J.M. Organic matter and water-stable aggregates in soil. Journal of Science Soil, v.33, p.141-163, 1982. 
TORMENA, C.A. Efeito do tráfico de máquinas em propriedades físicas do solo. In: SÁ, J.C.M. (Ed) Curso sobre manejo do solo no sistema plantio direto. Castro: Fundação ABC, 1996. p.52-77.

VALPASSOS, M.A.R.; CAVALCANTE, E.G.S.; CASSIOLATO, A.M.R.; ALVES, M.C. Effects of soil management systems on soil microbial activity, bulk density and chemical properties. Pesquisa Agropecuária Brasileira, v.36, p.1539-1545, 2001.

RAIJ, B. van; QUAGGIO, J.A.; CANTARELLA, H.;FERREIRA, M.E.; LOPES, A.S.; BATAGLIA, O.C. Analise química do solo para fins de fertilidade. Campinas: Fundação Cargill, 1987. 170p.

VANCE, E.D.; JENKINSON, D.S. Microbial biomass measurements in forest soils: determination of $\mathrm{Kc}$ valuer and tests of Hytotheses to explain the Failure of the cloroforn fumigation incubation method in acid soil. Soil Biology and Biochemistry, v.6, p.689-696, 1987.

VANCE, E.D.; BROOKES, P.C.; JENKINSON, D.S. An extraction method for measuring soil microbial biomass C. Soil Biology and Biochemistry, v.19, p.703$707,1987$.

VANCURA, V.; HANZLIKOVA, A. Root exudates of plants IV. Differences in chemical composition of seed and seedling exudates. Plant and Soil, v.36, p.271$282,1972$.

VEEN, J.A van; LADD, J.N.; AMATO, M. Turnover of carbon and nitrogen through the microbial biomass in a sandy loan and a clay soil incubated with $\left[{ }^{4} \mathrm{C}(\mathrm{U})\right]\left(\mathrm{NH}_{4}\right)_{2} \mathrm{SO}_{4}$ under different moisture regimes. Soil Biology and Biochemistry, v.17, p.747-756, 1985. 
VENZKE FILHO, S.P. Microbiota do solo e sua atividade em uma cronossequiência sob sistema plantio direto. Piracicaba, 1998. 98p. Dissertação (Mestrado) - Escola Superior de Agricultura “Luiz de Queiroz”, Universidade de São Paulo.

WITTER, E. Soil C balance in a long-term field experiment in relation to the size of the microbial biomass. Biology and Fertility of Soil, v.23, p.33-37, 1996.

ZWART, K.B.; DARBYSHIRE, J.F. Growth and nitrogenous excretion of a common soil flagellate Spumella sp. - a laboratory experiment. Journal of Soil Science, v.43, p.145-157, 1992. 